\title{
Simplified live-load moment distribution factors for simple span slab on I-girder bridges
}

Wesley D. Hevener

West Virginia University

Follow this and additional works at: https://researchrepository.wvu.edu/etd

\section{Recommended Citation}

Hevener, Wesley D., "Simplified live-load moment distribution factors for simple span slab on I-girder bridges" (2003). Graduate Theses, Dissertations, and Problem Reports. 1377.

https://researchrepository.wvu.edu/etd/1377

This Thesis is protected by copyright and/or related rights. It has been brought to you by the The Research Repository @ WVU with permission from the rights-holder(s). You are free to use this Thesis in any way that is permitted by the copyright and related rights legislation that applies to your use. For other uses you must obtain permission from the rights-holder(s) directly, unless additional rights are indicated by a Creative Commons license in the record and/ or on the work itself. This Thesis has been accepted for inclusion in WVU Graduate Theses, Dissertations, and Problem Reports collection by an authorized administrator of The Research Repository @ WVU. For more information, please contact researchrepository@mail.wvu.edu. 


\author{
Wesley D. Hevener \\ Thesis submitted to the \\ College of Engineering and Mineral Resources \\ at West Virginia University \\ in partial fulfillment of the requirements \\ for \\ Master of Science \\ in \\ Civil Engineering
}

Karl E. Barth, Ph.D., Chair

Julio F. Davalos, Ph.D.

Indrajit N. Ray, Ph.D.

Department of Civil and Environmental Engineering

\author{
Morgantown, West Virginia \\ 2003
}

Keywords: Load Distribution, Bridges, FEA 


\section{ABSTRACT \\ SIMPLIFIED LIVE-LOAD MOMENT DISTRIBUTION FACTORS FOR SIMPLE SPAN SLAB ON I-GIRDER BRIDGES}

\section{Wesley D. Hevener}

Live load distribution factors have been used in the design of highway bridges since the first edition of the AASHTO Standard Specifications were introduced in 1931. Revisions were made to the AASHTO Standard Specifications in 1943 based on work conducted by Newmark. These changes lead to the S/5.5 factor. In 1988, an effort was made to revise the AASHTO Standard Specification equation for live load distribution to produce less conservative results. NCHRP Report 12-26 successfully developed an equation involving girder spacing, girder span length, girder stiffness, and slab thickness; and was adopted into the AASHTO LRFD Specifications.

The primary goal of this effort is to identify and assess various methods of computing live load distribution factors and to use the results of laboratory and field tests to compare these methods. It is further a goal of this work to use these methods to perform a parametric study over a wide range of typical slab on steel I-girder bridges to assess the accuracy of both the AASHTO Standard and AASHTO LRFD specifications and to propose an empirical model that correlates better with the analytical results within the range of parameters that are to be studied.

These studies include: (1) a verification study into the FEA techniques used in modeling bridge geometry, (2) selection of procedure of calculating load distribution factors from FEA data, (3) a verification study of the selected procedure, (4) a parametric study to assess the influence of bridge parameters on the contribution to load distribution factors, (5) the development, using regression techniques, of a new equation for live load distribution factors, and (6) a comparison of proposed distribution factors against FEA, AASHTO LRFD, and AASHTO Standard Specifications.

Results from this work that over a wide range of typical bridge parameters both the AASHTO Standard and LRFD Specifications may produce conservative results and indicate the proposed equation provides a good foundation for the development of new equations for live load distribution factors. Girder spacing and girder span length were found to have the most influence of load distribution. The proposed equation developed showed good correlation to the FEA data and also correlated well against actual DOT bridge inventories used in the development of the AASHTO LRFD equation for live load distribution factors in slab on steel I-girder bridges. 


\section{ACKNOWLEDGEMENTS}

I would like to express my sincere gratitude to Dr. Karl Barth for the opportunity to pursue my master's degree at West Virginia University under his guidance and direction. The encouragement and support shown throughout my graduate study along with the valuable instruction will be instrumental in my future endeavors.

I would also like to thank Dr. Julio Davalos and Dr. Indrajit Ray for their participation on my graduate advisory committee.

Funding for this project was provided by the West Virginia Department of Transportation Division of Highways and is gratefully acknowledged. 


\section{TABLE OF CONTENTS}

Title Page.................................................................

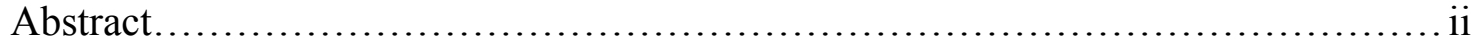

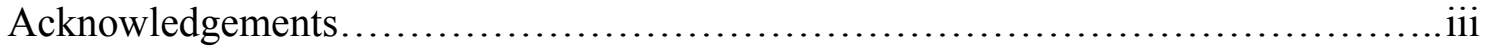

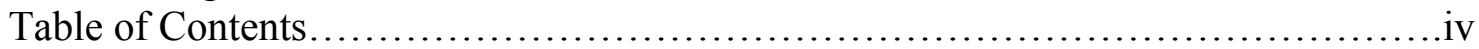

List of Tables.............................................................. vii

List of Figures........................................................... vii

Chapter 1: Introduction..................................................1

$1.1 \quad$ General........................................................ 1

1.2 Problem Statement........................................... 1

1.3 Scope of Work............................................... 2

1.4 Organization of Thesis........................................ 4

Chapter 2: Literature Review....................................... 5

2.1 Introduction...................................................... 5

2.2 AASHTO Standard Specifications................................. 5

2.3 AASHTO LRFD Specifications................................. 8

2.4 Ontario Highway Bridge Code $[\mathrm{OHBC}]$ and the Canadian Highway

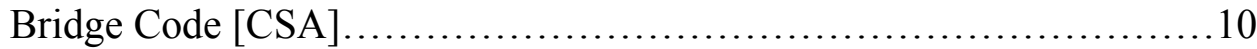

2.5 European Codes................................................ 10

2.6 Australian Bridge Code............................................ 11

2.7 Refined Analysis.............................................. 11

2.8 Studies Evaluating Current Distribution Factors...................... 12

2.8.1 Analytical Studies..........................................13

2.8 .2 Field Studies.................................................. 15

2.9 Factors Influence Live Load Distribution.............................. 16

2.9.1 Girder Spacing............................................... 16

2.9.2 Span Length................................................ 17

2.9.3 Girder Stiffness................................................ 17

2.9.4 Deck Thickness................................................... 19

2.9.5 Girder Location.............................................. 19

2.9.6 Continuity Conditions.................................... 20

2.9.7 Skew .............................................................

2.9.8 Cross Frame Characteristics..................................... 21

2.9.9 Secondary Stiffening Elements............................ 21

2.9.10 Composite Behavior...................................... 22

\section{Chapter 3: Development of Current AASHTO Load Distribution}

Factor Equations........................................... 23

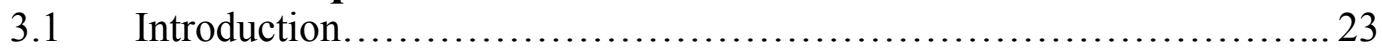

3.2 Method of Analysis Selection...................................... 23

3.3 Sensitivity Studies........................................... 24 


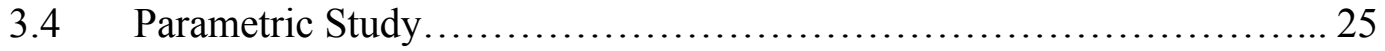

3.4.1 Database of State DOT Bridges............................... 25

3.4.2 Parametric Study Bridges.....................................26

$3.5 \quad$ Proposed Equations .............................................. 26

3.6 Determination of Accuracy of Proposed Equations......................2 28

\section{Chapter 4: Computation of Distribution Factors for Slab-on-Steel}

Girder Bridges............................................ 63

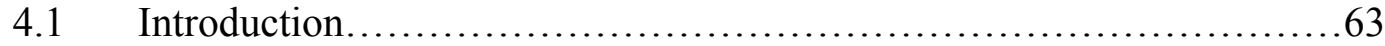

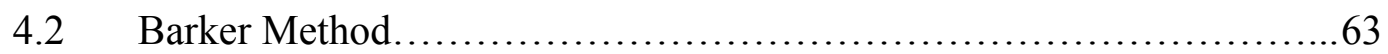

$4.3 \quad$ Stallings Method.................................................... 67

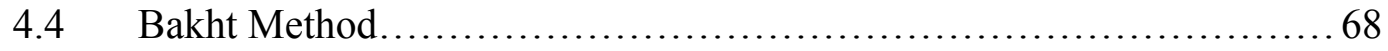

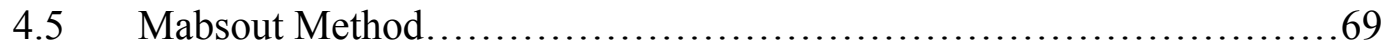

4.6 Example Calculations............................................. 70

4.6.1 Barker Method 1 for Positive Moment Region..................... 71

4.6.2 Barker Method 1 for Negative Moment Region.................... 74

4.6.3 Barker Method 2 for Positive Moment Region..................... 76

4.6.4 Barker Method 2 for Negative Moment Region.................... 76

4.6.5 Stallings Method for Positive Moment Region...................... 77

4.6.6 Stallings Method for Negative Moment Region..................... 78

4.6.7 Bakht Method for Positive Moment Region....................... 78

4.6.8 Bakht Method for Negative Moment Region........................79

4.6.9 Mabsout Method for Positive Moment Region..................... 80

4.6.10 Mabsout Method for Negative Moment Region..................... 81

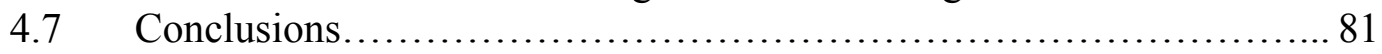

Chapter 5: Verification Studies...................................... 89

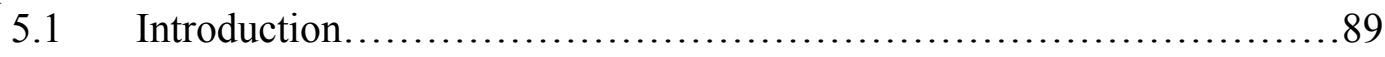

5.2 Description of FEA modeling tools......................................99

$5.3 \quad$ Verification Studies................................................... 91

5.3.1 Comparison with Newmark Bridge..............................91

5.3.2 Comparison with FHWA-AISI Bridge...........................92

5.3.3 Comparison with Bakht Medium Span Length Bridge............... 94

5.3.4 Comparison with Stallings Bridges................................. 96

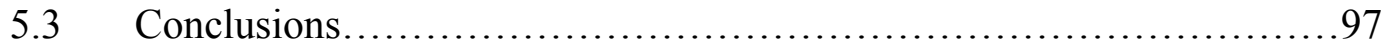

Chapter 6: Parametric Studies....................................... 110

$6.1 \quad$ Introduction......................................................... 110

6.2 Range of Parameters............................................. 110

$6.3 \quad$ General Results.............................................. 113

6.3.1 Influence of girder spacing............................... 114

6.3.2 Girder span length............................................ 114

6.3.3 Steel yield strength........................................ 114

6.3.4 Span to depth ratio.............................................. 115

6.4 Further Data Reduction.......................................... 115 


\section{Chapter 7: General Results and Development of Proposed Moment}

Distribution Factors......................................... 127

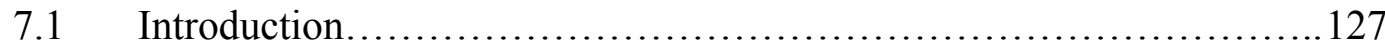

7.2 Development of Proposed Equation............................... 127

7.3 Comparisons of Proposed Equation...................................129

7.4 Conclusions.................................................... 130

Chapter 8: Summary and Concluding Remarks........................ 134

$8.1 \quad$ Scope of Work.................................................. 134

$8.2 \quad$ Summary Results................................................ 135

$8.3 \quad$ Future Work .................................................... 136

Reference Cited............................................................... 137 


\section{LIST OF TABLES}

Table 3.1 Parametric values used in development of LRFD distribution factors for beam-and-slab bridges..................................... 30

Table 3.2 NCHRP 12-26 database of bridges.............................. 31

Table 3.3 Parameter ranges for NCHRP 12-26 bridge database.....................46

Table 3.4 NCHRP 12-26 parametric study database......................... 47

Table 3.5 Representative AASHTO LRFD distribution factors (Partial Reprint from AASHTO Table 4.6.2.2.2b-1).................................54

Table 4.1 Bottom-flange strains, stresses, and D values for AISI-FHWA bridge calculations................................................. 83

Table 4.2 Mabsout method results showing the element stress, area, distance from neutral axis, and calculated moments for the positive moment

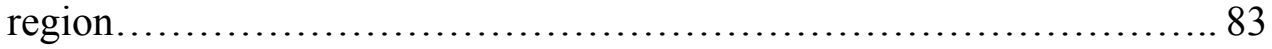

Table 4.3 Mabsout method results showing the element stress, area, distance from neutral axis, and calculated moments for the negative moment region..................................................... 84

Table 4.4 Results from example distribution factor calculation....................84

Table 5.1 Example distribution factors for Newmark bridge..................... 99

Table 5.2 Design factors for Bakht medium span bridge.......................99

Table 5.3 Distribution factors for Stallings's bridge............................ 100

Table 6.1 Key parameters for WVU parametric bridges...................... 116

Table 6.2 Summary of FEA results distribution factors calculated from WVU parametric study

Table 7.1 Comparison of distribution factors comparing proposed, AASHTO LRFD, and AASHTO Standard specification done on four bridges from the WVU small bridge inventory, Bakht, and Stallings. 


\section{LIST OF FIGURES}

Figure $3.1 \quad$ Histogram of relative frequency for span length.......................55

Figure 3.2 Histogram of relative frequency for clear roadway width................55

Figure 3.3 Histogram of relative frequency for skew.......................... 56

Figure 3.4 Histogram of relative frequency for number of girders...................56

Figure 3.5 Histogram of relative frequency for girder spacing...................57

Figure 3.6 Histogram of relative frequency for slab thickness....................5 57

Figure 3.7 Histogram of relative frequency for girder depth..................... 58

Figure 3.8 Histogram of relative frequency for roadway width (out-to-out)........58

Figure 3.9 Histogram of relative frequency for deck overhang................... 59

Figure 3.10 Histogram of relative frequency for girder area....................... 59

Figure 3.11 Histogram of relative frequency for girder moment of inertia.......... 60

Figure 3.12 Histogram of relative frequency for eccentricity.....................6 60

Figure 3.13 Histogram of relative frequency for bridge construction date...........61

Figure 3.14 Comparison of proposed distribution factors vs. analytical results.......61

Figure 3.15 Comparison of proposed distribution factors vs. MSI results........... 62

Figure 4.1 Diagram of variables found in Eqn. 4.3 for least squares method......... 85

Figure 4.2 Diagram of the componets used to compute elastic moment calculated in

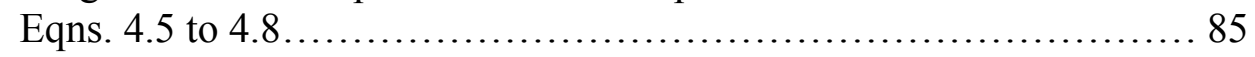

Figure 4.3 AISI-FHWA bridge cross-section................................ 86

Figure 4.4 AISI-FHWA bridge plan view showing the location of flange transitions .......................................................... 86

Figure 4.5 Cross section of girder profiles for AISI-FHWA bridge............... 87

Figure 4.6 Transverse load positions for AISI-FHWA bridge .....................8 87 
Figure 4.7 Hypothetical loading position of a line of wheels for the calculation of

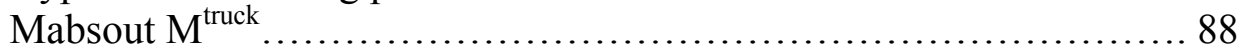

Figure 5.1 Typical FEA mesh discretization for a WVU bridge model.............101

Figure 5.2 Newmark bridge cross-section with horizontal loading positions......... 101

Figure 5.3 Plan view of the Newmark Bridge showing the longitudinal dimensions and loading......................................................... 102

Figure 5.4 Comparison of deflection between Newmark experimental testing and WVU FEA for the Newmark bridge in Section 5.2.1..................102

Figure 5.5 Bottom-Flange Stress for 0.44L-1 Lane-Loaded comparing Actual Data, Tiedeman et al. FEA results, and WVU FEA results.................. 103

Figure 5.6 Bottom-Flange Stress for 0.44L-3 Lanes-Loaded comparing Actual Data, Tiedeman et al. FEA results, and WVU FEA results................... 103

Figure 5.7 Bottom-Flange Stress for 0.65L-1 Lane-Loaded comparing Actual Data, Tiedeman et al. FEA results, and WVU FEA results.................... 104

Figure 5.8 Bottom-Flange Stress for 0.65L-3 Lanes-Loaded comparing Actual Data, Tiedeman et al. FEA results, and WVU FEA results................... 104

Figure 5.9 Cross-section view of Bakht medium span length bridge.................... 105

Figure 5.10 Plan view of Bakht bridge showing girder transitions and cross-frame

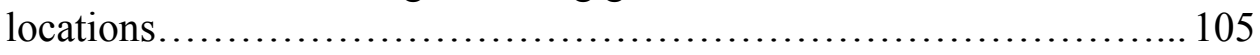

Figure 5.11 Cross-sections for Bakht medium span length bridge.................. 106

Figure 5.12 Plan view showing the location of longitudinal loading for each load case involving a (a) Kenworth and (b) Mack truck......................... 106

Figure 5.13 Plan view showing the location of transverse loading positions for each load case involving a (a) Kenworth and (b) Mack truck................. 107

Figure 5.14 Comparison of deflection from the Bakht field-testing and WVU FEA model for the 3 load cases presented in Section 5.2.3 .................. 108

Figure 5.15 Stalling bridge cross-section and horizontal truck loading positions.... 108

Figure 5.16 Cross-section for Stallings's bridges................................. 109 
Figure 5.17 Plan view of Stalling bridges showing longitudinal dimensions and loading for two truck tests.

Figure 6.1 Cross-section view and horizontal loading positions for all bridges included in the WVU parametric study for cross-section 1

Figure 6.2 Cross-section view and horizontal loading positions for all bridges included in the WVU parametric study for cross-section $2 \ldots \ldots \ldots \ldots \ldots 122$

Figure 6.3 Cross-section view and horizontal loading positions for all bridges included in the WVU parametric study for cross-section 3.

Figure 6.4 Hypothetical girder elevation for girder configurations found in Table

6.1

Figure 6.5 Elevation and longitudinal loading positions for girders found in Table 6.1

Figure 6.6 Sensitivity study comparing girder stiffness against span length for the WVU parametric study, LRFD parametric study, NCHRP DOT inventory, and WVU small DOT inventory. 124

Figure 6.7 Sensitivity study comparing design factor, D, against girder spacing for the WVU parametric study ....................................... 125

Figure 6.8 Sensitivity study comparing design factor, D, against span length for the WVU parametric study. ...

Figure 6.9 Sensitivity study comparing design factor, D, against girder spacing for the WVU parametric study ...................................... 126

Figure 7.1 Comparison of actual FEA design factor values plotted against proposed design factor values

Figure 7.2 Histogram of proposed distribution factors over the actual FEA distribution factors.

Figure 7.3 Histogram of the AASHTO LRFD distribution factors over the actual FEA distribution factors

Figure 7.4 Histogram of the AASHTO Standard distribution factors over the actual FEA distribution factors. 


\section{CHAPTER 1}

\section{INTRODUCTION}

\subsection{General}

Analytical studies were performed for simply supported, slab-on-stringer bridges ranging in girder spacing, span length, steel yield strength, and span-to-depth ratio. The main objectives of the studies were to verify finite element data from previous researchers, compare results of analytical modeling with data obtained from field-testing, and develop an improved equation for calculating the distribution of wheel loads on highway bridges.

\subsection{Problem Statement}

Live load distribution factors (also referred to as girder distribution factors and load distribution factors) are commonly used by bridge engineers in order to simplify the complex, three-dimensional behavior of a bridge system. Specifically, these factors allow for the designer or analyst to consider bridge girders individually by determining the maximum number of lines of wheels (or vehicles) that may act on a given girder. Current American specifications give relatively simple, empirical equations for calculation of these distribution factors; however they contain parameters which are difficult for the design engineer to work with primarily for initial member sizes. 
Although, several researchers have shown through analytical and field studies that these equations can be inaccurate in some circumstances. The relatively recent adoption of the LRFD specifications has resulted in enhanced accuracy for bridges having geometries similar to those considered in developing the equations. However, for bridges with span lengths, girder spacings, etc. outside of these ranges, overly conservative results are often obtained. Therefore, there is a need to develop more comprehensive distribution factors that will provide a more accurate approximation of live load response and maintain simplicity of use.

The goal of this research study is to develop less complex live-load distribution equations with accuracy appropriate for design. These new equations will be less restrictive in their ranges of applicability than the present LRFD distribution factors, represent a more reasonable range of bridges being designed today, and provide a more simplistic approach. The proposed ranges of applicability will minimize the need for more refined analysis and will help to facilitate the use of the traditional line girder approach.

\subsection{Scope of Work}

The current bridge design codes and evaluation methods are often overly conservative for computing the live load distribution factors. As a result, a number of existing bridges can be over designed creating for more uneconomical designs. Therefore, this study attempts to create an improved methodology for computing a more 
accurate live load distribution factor to use in design, and to eventually propose the modification of the current provisions for the design and evaluation of existing bridges.

The specific objectives of this research are:

1. To review previous work done by other researchers on live load distribution factors to determine the importance of particular parameters, gain an understanding on the analysis methods previously used, and to understand how the existing methods were derived.

2. To determine an accurate approach to compute distribution factors from finite element data.

3. To verify the selected approach against laboratory and field test data as well as to compare results with analytical models developed by other researchers.

4. To compute distribution factors from a parametric study of bridges ranging in length, steel strength, and span-to-depth ratios. The distribution factors from previous researchers are also computed, especially the NCHRP Report 12-26.

5. To determine a more simplistic approach to computing distribution equations from the previously calculated distribution factors using a regression method.

6. To recalcalulate the distribution factors of all previously modeled bridges and compare with the previous methods prescribed by the codes.

7. To document the results and present in an orderly fashion for proposal of improving the existing specifications. 


\subsection{Organization of Thesis}

The thesis is organized into eight chapters. Chapter 1 presents an overview of the problem along with a summary of background information, along with the scope and objectives of this study. Chapter 2 presents a literature review of previous research focused on live load distribution factors for slab on steel I-girder bridges.

Chapter 3 discusses the development of the current AASHTO LRFD load distribution factor equation. The chapter focuses on the selection of analysis tools, development of sensitivity and parametric studies, the proposed equations, and the verification methods utilized in NCHRP 12-26 (1988), the primary research project undertaken to develop current AASHTO LRFD load distribution factor equations. Chapter 4 contains the computation of live load distribution factors for slab on steel girder bridges using different methods prescribed by previous researchers to aid in the selection of a method for use in this study. Chapter 5 provides a verification study done recreating bridges from previous analytical and field-testing research to compare the methods described in Chapter 4 with the recorded results from the research to select an effective method to compute live load distribution factors. Chapter 6 presents a parametric study of simply supported bridges focused on assessing load distribution factors using a discrete range of parameters. Summary information is provided regarding trends in key design parameters and comparisons are made between analytical values and current code predictions. Chapter 7 discusses the development of a more accurate and simplistic method of computing live load distribution factors. Chapter 8 provides a summary and conclusion for the work done and results obtained for this thesis. 


\section{CHAPTER 2}

\section{LITERATURE REVIEW}

\subsection{Introduction}

This section contains a concise summary of the development of present live load distribution factors. These factors have been incorporated in American bridge codes since the publication of the first edition of the AASHO Standard Specifications in 1931 (AASHO, 1931). The current Standard Specifications (AASHTO, 1996) still include these original distribution factors with relatively minor modifications. In 1994, AASHTO adopted the LRFD Bridge Design Specifications. These Specifications contained a new form of distribution factors that represented the first major change to these equations since 1931. A description of the distribution factors contained in these two codes of practice and their historical development is presented in this section. A brief overview of the methods specified for live load distribution in selected foreign bridge codes is also included.

\subsection{AASHTO Standard Specifications}

Distribution factors in the Standard Specifications are typically given in the form $\mathrm{S} / D$; where $\mathrm{S}$ is the distance between girders (in $\mathrm{ft}$.) and $D$ is a constant that varies depending on the bridge type. Also, slightly more complex equations are given for precast multibeam bridges (AASHTO article 3.23.4), spread box girder bridges 
(AASHTO article 3.28) and steel box girder bridges (AASHTO article 10.39.2).

Distribution factors for these bridge types are not solely a function of girder spacing, and instead parameters such as the number of design lanes, number of girders, stiffness parameters, span length, and roadway width also influence the distribution factor.

The current distribution factor for composite steel I-beam bridges with two or more design lanes (S/5.5) was developed by Newmark and Siess (1943) providing a major revision to load distribution factor procedures presented in the first two editions of the AASHTO Standard Specifications. Newmark and Siess approached the slab on girder study using a beam on elastic foundation approach. Specifically, they considered a portion of the slab to act as a beam supported by girders that were approximated as elastic supports. They then used moment distribution to determine the beam response and suggested the following general expression for live load distribution in interior girders (Newmark and Siess, 1942)

$$
D=4.4+0.42 \frac{L}{10 \sqrt{H}}
$$

where $\mathrm{L}=$ span length

$\mathrm{H}=\quad$ stiffness parameter defined as $\frac{E_{b} I_{b}}{L E I}$

$E_{b}=$ modulus of elasticity of the material of the beam

$\mathrm{I}_{\mathrm{b}}=$ moment of inertia of the cross section of the beam

$\mathrm{E}=$ modulus of elasticity of the slab material

$\mathrm{I}=\quad$ moment of inertia per unit of width of the cross section of the slab.

By examining typical values of $\mathrm{L}$ and $\mathrm{H}$ for simple span bridges having span lengths of 20 to $80 \mathrm{ft}$. and girder spacings of 5 to $8 \mathrm{ft}$., the distribution factor was further simplified 
to the current form of S/5.5 (Newmark and Siess, 1943). The accuracy of this resulting distribution factor was verified experimentally using quarter scale right bridges (Newmark, 1949). Subsequent experimental tests were done on quarter scale right and skewed brides (Newmark et al., 1946; Newmark et al., 1948) to determine the relevance of the S/5.5 with close comparisons shown for small skew angles. Over the years, the range of applicability of Newmark's expression has been increased.

Specifically, Newmark and Siess considered only simply supported, non-skewed bridges, with span lengths ranging from 20 to 80 feet. The girder spacing of the bridges used to develop this distribution factor ranged from 5 to $8 \mathrm{ft}$., while today the equation is considered valid for girder spacings up to $14 \mathrm{ft}$. Also, at the time the $\mathrm{S} / 5.5$ factor was developed, the standard design lane was $10 \mathrm{ft}$. wide, while today $12 \mathrm{ft}$. design lanes are customary.

Throughout the past seventy years, there have been numerous studies related to load distribution of vehicular loads. As a result of the findings of some of these efforts, modifications have been made to the distribution factors provided in the Standard Specifications, with the goal of providing improved accuracy. There have been many instances, however, where this has led to inconsistencies in the manner in which distribution factors are calculated. Sanders (1984) summarizes these conflicts as follows.

- The majority of the distribution factors have been determined by considering only a limited number of parameters (typically floor type, beam type, and girder spacing), while additional parameters have been included for other bridge types (stiffness parameters, span length, etc.).

- There is a variation in the format of the distribution factors for bridges of similar construction (i.e., steel I-girders, composite box beams, precast multibeams, and spread box beams). 
- The Standard Specifications include provisions for a reduction in live load intensity as the number of design lanes increases. This provision has been inconsistently considered during the development of various distribution factors.

- Changes in the number, position, and width of traffic lanes have been randomly incorporated in the distribution factor expressions.

- Lastly, there are discrepancies regarding the level of research performed for various distribution factors.

\subsection{AASHTO LRFD Specifications}

The load distribution factors presented in the AASHTO LRFD Specifications are in a large part based on work conducted in the NCHRP Report 12-26. The equation was develop based on parameters from a parametric study developed from a set of 364 existing bridges from several differing geographic regions represented by ten different states comprised of three different types of bridges: prestressed T-beam, concrete Igirder, and steel I-girder.

One of the initial tasks in NCHRP 12-26 was to conduct modeling studies to assess the capabilities of various software packages to predict lateral load distribution in bridge superstructures. Models were created for fifteen bridges using grillage, equivalent orthotropic plate, concentrically stiffened plate, eccentrically stiffened plate, and folded plate models.

Sensitivity studies were conducted in order to access the effect of various parameters on live load distribution using an "average" reinforced concrete T-beam bridge where only one parameter at a time was varied. Parameter ranges used in the sensitivity studies were based on the 364 bridge database. After analyzing the sensitivity 
of the distribution factors, the only parameters used in the parametric study were girder spacing, span length, girder stiffness, and slab thickness. The database of existing bridges was again used to determine representative values for these four parameters in order to develop a parametric study.

The results of both the sensitivity studies and the parametric studies were used to develop new equations for live load distribution. Based on the results of the sensitivity studies, equations were developed for moment with one design lane, moment with two or more design lanes, end shear with one design lane, and end shear with two or more design lanes for bridges within the range of parameters used in the sensitivity study.

Alternatively, results from the parametric study were used to develop equations for moment and shear for one and multiple design lanes using a multidimensional space interpolation (MSI) method. The equations derived using the MSI methods are not presented in the NCHRP reports.

The accuracy of the distribution factor equations developed as a result of the sensitivity studies was evaluated using two methods. First, analytical methods were created using randomly selected bridges from the database and the resulting distribution factor was compared with that from the proposed equations. The distribution factors were compared to the corresponding factors developed using the MSI method for a large number of randomly selected bridges from the database.

Chapter 3 gives a thorough description and layout of the process used in the development of the AASHTO LRFD Specification equation for live load distribution factors. 


\subsection{Ontario Highway Bridge Code [OHBC] and the Canadian Highway Bridge Code [CSA]}

The Ontario Highway Bridge Code uses live load distribution factors that have a similar $\mathrm{S} / D$ format to the US Standard Specifications (1991). However, the OHBDC prescribes a unique approach for determination of $D_{d}$ that is based on the research of Bakht and Moses (1988) and Bakht and Jaeger (1990). The value of $D_{d}$ (and subsequent variables incorporated in expressions for $D_{d}$ ) varies based on the limit state of interest and for moment versus shear.

The recent adoption of the national Canadian Highway Bridge Code (CSA, 2000) has also incorporated the work of Bakht and Moses (1988) and Bakht and Bakht and Jaeger (1990). However, this specification essentially uses a live load distribution factor in which the force effect of interest (i.e., moment of shear) is distributed based on the number of design lanes divided by the number of girders. Modification factors are then applied to these expressions to account for multilane loading and other effects as a function of the limit state of interest.

\subsection{European Codes}

Most European Common Market countries base their design specifications upon the Euro codes (Dorka, 2001). The Eurocodes are only a framework for national standards. Each country must issue a "national application document (NAD)" which specifies the details of their procedures. A Euro code becomes a design standard only in connection with the respective NAD. Thus, there is considerable variation in the design 
specifics from country to country. However, the codes used in many European countries generally do not use simplified methods (such as distribution factors) to determine the live load affect on bridges. Rather, more detailed analysis methods are typically used (Nutt et al., 1988).

\subsection{Australian Bridge Code}

Similar to the practices of most European countries, the Australian bridge code (Austroads, 1992) does not incorporate distribution factors for live load. Instead, the number of design lanes is determined based on roadway width, and then these lanes are positioned to give the maximum load effect as a result of refined analysis methods. "Multiple lane modification factors" are incorporated (similar to American multiple presence factors) which reduce the load applied to each lane as the number of design lanes increases.

\subsection{Refined Analysis}

While the use of the empirical equations described above is the most common method of determining distribution factors, both the AASHTO Standard and LRFD Specifications also allow the use of more refined analysis techniques to determine the transverse distribution of wheel loads in a bridge superstructure. Specifically, two other methods with increasing complexity and reliability are given. 
The first level of refined analysis permitted in the specifications is to utilize computer aided techniques in order to determine appropriate wheel load distribution factors. Specifically, computer programs have been developed that simplify bridge behavior using influence surface or influence section concepts, which are then used to determine distribution factors.

For bridges that do not meet the geometric limitations required for the use of simplified distribution factors, detailed computer analysis may be used. In these situations, the actual forces occurring in the superstructure are calculated and the use of distribution factors is not necessary. When these methods are employed, it is the responsibility of the designer to determine the most critical location of the live loads. The LRFD Specifications (1998) give several examples of acceptable methods of analysis including (but not limited to): finite element modeling, grillage analogy method, and the folded plate method.

\subsection{Studies Evaluating Current Distribution Factors}

Several investigators focused on examining the accuracy of the current AASHTO distribution factors based on research conducted. These efforts have included both analytical studies using finite element analysis and field studies of existing bridges. 


\subsubsection{Analytical Studies}

Many studies by various researchers have shown that the lateral distribution of live load predicted by expressions in both the current AASHTO Standard Specifications and LRFD Specifications can be overly conservative. The bulk of these efforts have been focused on limited parameter variations such as the influence of span length, skew, girder spacing, etc.

Hays et al. (1986) and Mabsout et al. (1999) have both investigated the accuracy of the Specifications compared to varying span lengths. A similar range of span lengths was investigated in both studies, with span varying from 30 to $120 \mathrm{ft}$. Hays et al. compared the results of their analytical study to distribution factors resulting from the Standard Specifications and the OHBDC and show that the Standard Specifications are unconservative for interior girders with span lengths less than $60 \mathrm{ft}$. They also demonstrate that while the OHBDC is somewhat conservative, it is very accurate in capturing the non-linear relationship of decreasing distribution factor with increasing span length. Mabsout et al. (1999) obtained similar results from their analytical studies. They state that the Standard Specifications are less conservative than the LRFD Specifications for span lengths up to $60 \mathrm{ft}$. and girder spacing up to $6 \mathrm{ft}$. Although, as span length and girder spacing increase, the Standard Specifications were found to become more conservative. Mabsout et al. also found their finite element result to be reasonably close the results predicted by the LRFD equations.

Other researchers have investigated the accuracy of the current distribution factors for bridges with varying degrees of skew. One such study was that of Arockiasamy et al. 
(1997). The authors investigated angles of skew ranging from 0 to 60 degrees and concluded that the LRFD code is accurate in capturing the effects of skew for beam-andslab bridges, particularly for skew angles in excess of 30 degrees. Arockiasamy et al. also state that the LRFD equations overestimate the effect of slab thickness.

Analytical studies conducted by Barr et al. (2001) investigated the accuracy of the LRFD distribution factors while varying several parameters. These parameters included: skew, simply supported versus continuous spans, presence of interior and end diaphragms, and presence of haunches. Results of this work indicate that for models similar to those used in developing the LRFD equations (simple-spans, without haunches, interior diaphragms, or end diaphragms), the equations are reliable and are $6 \%$ conservative on average. However, when these additional parameters are included in the model, the distribution factors given by the specifications are up to $28 \%$ conservative. Specifically, the authors found that: (1) including the presence of haunches and end diaphragms significantly reduced the distribution factors, (2) the effects of including intermediate diaphragms in the model were negligible, and (3) the effects of continuity increased the distribution factor in some cases and decreased it in others. In addition, these researchers also found the effects of skew to be reasonably approximated by the LRFD equations. Also, the OHBDC procedures were shown to capture the effects of skew with high precision. However, these specifications are only valid for angles of skew not exceeding 20 degrees.

In analytical studies by Shahawy and Huang (2001), the focus was on the accuracy of the LRFD equations as a function of span length, girder spacing, width of deck overhang, and deck thickness. The authors found that results from the LRFD 
equations can have up to $30 \%$ error for some situations, particularly when girder spacing exceeds $8 \mathrm{ft}$. and deck overhang exceeds $3 \mathrm{ft}$.

\subsubsection{Field Studies}

Field-testing of two simply supported, steel I-girder bridges was performed by Kim and Nowak (1997). One bridge, designated as M50/GR had a span length of $48 \mathrm{ft}$. and a girder spacing of $4 \mathrm{ft}$. - 9in. The second bridge, referred to as US23/HR, had a span length of $78 \mathrm{ft}$. and a girder spacing of $6 \mathrm{ft}$ - -3 in. It was shown that the LRFD distribution factors overestimated the actual distribution by $28 \%$ and $19 \%$ in the two bridges tested. Furthermore, the distribution factors obtained from the Standard Specifications were $16 \%$ and $24 \%$ greater than the actual distribution factors that resulted from field-testing.

Fu et al. (1996) conducted live load tests on four steel I-girder bridges of which three were tangent bridges and one was skewed. Comparison of the field test results to the LRFD distribution factors showed the code to be $13 \%$ to $34 \%$ conservative for the tangent bridges and 13\% unconservative for the skewed bridge.

Additional field-testing of seventeen steel I-girder bridges was conducted by Eom and Nowak (2001). The bridges used in the study had span lengths ranging from 32 to $140 \mathrm{ft}$. and girder spacings from $4 \mathrm{ft}$. to $9 \mathrm{ft}$. -4 in. The majority of the bridges were not skewed, but some moderately skewed bridges (10 to 30 degrees) were also included. Actual distribution factors obtained from the field tests were lower than those given by the specifications in all cases. It was found that the Standard Specifications were very 
conservative for short spans with small girder spacings, and even more conservative for other situations. Also, the LRFD distribution factors were found to be more accurate than those from the Standard Specifications, although were still considered to be too conservative.

\subsection{Factors Influence Live Load Distribution.}

The procedures used to calculate live load distribution factors involve several different factors ranging from girder spacing to girder stiffness. The following paragraphs give a description of the different factors that were studied in order to determine the most important factors to be included in the new specifications.

\subsubsection{Girder spacing}

Girder spacing has been considered to be the most influential parameter affecting live load distribution since early work by Newmark (1938). Newmark and Siess (1942) originally developed simple, empirical equations expressing distribution factors as a function of girder spacing, span length, and girder stiffness. Later, (Newmark, 1949) the effect of the other two parameters was neglected and the distribution factors were expressed as a linear function of girder spacing only. These relationships are still incorporated in the Standard Specifications with minimal changes since their adoption.

Even though girder spacing is influential, it has been shown through analytical and field studies that the $\mathrm{S} / D$ factor consistently overestimates the actual live load 
distribution factors. Also, sensitivity studies presented in NCHRP Report 12-26 (Nutt et al., 1988) and analytical studies by Tarhini and Frederick (1992) show that while girder spacing significantly effects live load distribution characteristics, the relationship is not linear as implied by the $\mathrm{S} / D$ method, and thus does not correlate well with the AASHTO Standard Specifications.

\subsubsection{Span length}

Nutt et al. (1988) determined that a non-linear relationship existed between span length and girder distribution factors. This relationship was most significant for moment in interior girders (moment and shear, as well as interior and exterior girders were evaluated in this study).

Tarhini and Frederick (1992) also observed a non-linear (quadratic) relationship between span length and the girder distribution factor. In this study, the quadratic increase in the distribution factor with increasing span length is due to the potentiality for an increased number of vehicles present on a longer bridge.

\subsubsection{Girder stiffness}

Newmark and Siess (1942) expressed the amount of live load distributed to an individual bridge girder in terms of the relative stiffness of the girder compared to the stiffness of the slab, expressed by the dimensionless parameter H (see AASHTO 
Standard Specifications section). Results demonstrated that the relative stiffness (as defined by the parameter $\mathrm{H}$ ) had a small effect on live load distribution.

Tarhini \& Frederick (1992) also found girder stiffness to have a small, but negligible effect on live load distribution. For example, they studied the effects of relatively large changes in the moment of inertia of the cross section such as doubling the cross-sectional area of the girder and altering the thickness of the slab. These changes resulted in approximately a $5 \%$ difference compared to the original design, which the authors considered to be insignificant.

Nutt et al. (1988) defined girder stiffness by the parameter $\mathrm{K}_{\mathrm{g}}$

$$
K_{g}=I+A e^{2}
$$

where A and I are the area and moment of inertia of the girder cross section, respectively, and $\mathrm{e}$ is the distance between the centers of gravity of the slab and beam. In order to confirm that this was an acceptable means of quantifying girder stiffness, individual values of moment of inertia, area and eccentricity were varied, while maintaining a constant value of $\mathrm{I}+\mathrm{Ae}^{2}$. It was observed that varying individual parameters was relatively inconsequential and that there was only a $1.5 \%$ difference obtained due to varying these individual parameters if $\mathrm{I}+\mathrm{Ae}^{2}$ was held constant. By defining girder stiffness in this manner, Nutt et al. (1988) found there was a significant relationship between girder stiffness and live load distribution. The effects of varying torsional stiffness were also evaluated in this study with results showing this parameter has only a relatively small impact on girder distribution factors ( $3 \%$ difference). 


\section{2..9.4 Deck Thickness}

Conflicting information exists regarding the effect of the thickness of concrete decks on live load distribution. Newmark (1949) states that deck thickness will affect wheel load distribution, as deck thickness will have a direct influence on the relative stiffness. Although, in research by Tarhini \& Frederick (1992), bridges having a slab thickness ranging from 5.5 to 11.5 in. were analyzed and it was found that these changes had a negligible effect on live load distribution.

Nutt et al. (1998) also considered the effect of this parameter to be small $(10 \%$ difference between bridges with 6 and 9 in. slabs). Nonetheless, they did include this parameter in the recommended distribution factor equations contained in NCHRP Report $12-26$

\subsubsection{Girder location}

Girder location, i.e. interior vs. exterior, was found to have an influence on liveload distribution factors by Walker (1987). Specifically, results demonstrated that the $\mathrm{S} / D$ factors overestimate actual distribution to a lesser extent in exterior girders.

Zokaie (2000) states that edge girders are more sensitive to truck placement than interior girders. Therefore, either the lever rule or a correction factor could be used.

The width of deck overhang may be one contributing factor to the difference in distribution between interior and exterior girders. Specifically, deck overhang has been 
shown to have a linear effect on live-load distribution to the exterior girder, while deck overhang is considered to have a negligible effect on interior girders (Nutt et al., 1988).

\subsubsection{Continuity conditions}

Nutt et al. (1988) also examined the difference in distribution factors between simple span and two-span continuous bridges. The results showed that the distribution factors obtained for the two-span bridges were 1 to $11 \%$ higher than the distribution factors that resulted for the corresponding simple-span bridges.

Later research by Zokaie (2000) states that there is a 5\% difference between positive moments and $10 \%$ difference between negative moments for continuous versus simple span bridges. However, it is assumed that moment redistribution will cancel this effect and no correction factor is recommended (or included) for use in the LRFD Specifications.

\subsubsection{Skew}

Nutt et al. (1988) observed that skew did affect live load distribution. Specifically, increasing skew tends to decrease the wheel load distribution for moment and increase the shear force distributed to the obtuse corner of the bridge. In addition, they found this to be a non-linear effect and also state that this effect will be greater for increasing skew. 


\subsubsection{Cross Frame Characteristics}

Walker (1987) has investigated the effect of diaphragms with the following results. For a load applied near the curb, the difference between the two types of models (with and without diaphragms) was negligible. Although, for a load transversely centered, the effect of cross frames is more pronounced.

Field studies by Kim \& Nowak (1997), indicated that relatively widely spaced diaphragms lead to more uniform girder distribution factors between girders, although no information is provided regarding a relationship between increasing or decreasing distribution with cross frame spacing.

Nutt et al. (1988) state that cross bracing can have an important role in live load distribution. However, they give two reasons for not considering this parameter in their sensitivity studies: (1) the effect of interior cross frames decreases as the number or loaded lanes increases, and (2) the effect of these members is difficult to predict, as many field studies have shown diaphragms to be less effective than predicted in design.

\subsubsection{Secondary Stiffening Elements}

Research reported by Mabsout et al. (1997) indicates a distinct relationship between the presence of sidewalks and railings and girder distribution factors. Results for various combinations of sidewalk and/or railing on one or both sides of the bridge are compared with distribution factors obtained from current LFD and LRFD Specifications. In summary, depending on the combination and location of stiffening elements added 
(sidewalk and/or railing, one or both sides of the bridge), the researchers found that the current LRFD girder distribution factors are 9 to $30 \%$ higher than those obtained in the finite element studies.

Nutt et al. (1988) point out that while secondary stiffening elements do affect live load distribution, considering these members (such as curbs and parapets) in design may be unconservative. For example, if the bridge were widened subsequent to its original design, the curbs and parapets would be removed. Therefore, the enhanced distribution as a result of these elements would be lost, and girders designed to take advantage of this behavior may become overstressed.

\subsubsection{Composite Behavior}

Based on analytical results, Tarhini \& Frederick (1992) found the effect of composite vs. noncomposite construction to have a negligible effect on wheel load distribution in I-girder bridges. The difference in girder distribution factors for composite vs. non-composite bridges was 6 percent for a short span bridge ( $35 \mathrm{ft}$.) and 1.5 percent for a relatively long span bridge (119 ft.). 


\section{CHAPTER 3}

\section{DEVELOPMENT OF CURRENT AASHTO LOAD DISTRIBUTION FACTOR EQUATIONS}

\subsection{Introduction}

The current distribution factors contained in the AASHTO LRFD Specification for slab-on-girder bridges are a result of the NCHRP Project 12-26, conducted by Imbsen \& Associates (Nutt et al., 1988). This study focused on the development of new distribution factors and was initiated by a desire for more accurate distribution factors. Another goal of the project was to reduce the inconsistencies that exist in the Standard Specifications.

\subsection{Method of Analysis Selection}

An initial phase of this project was to select an appropriate method of analysis to be used in this study. Analytical models of fifteen previously field-tested bridges using five different modeling techniques were used to aid in the process. This group of bridges was comprised of concrete T-beam, concrete I-girder, steel I-girder, and continuous slab bridges. In addition one prestressed concrete box girder bridge was also evaluated. The bridges tested consisted of simply supported, single span bridges, and also two- and three-span continuous bridges. Straight and curved girders were included along with right and skewed bridges. Span lengths of these bridges ranged from $10 \mathrm{ft}$. (in case of a scale model) to $100 \mathrm{ft}$. Models were created of the bridges using grillage, equivalent 
orthotropic plate, concentrically stiffened plate, eccentrically stiffened plate, and folded plate models. An evaluation of the results from the analytical models were compared to the field-testing results, which led the researchers to select the eccentrically stiffened plate and grillage models for use in the subsequent sensitivity studies.

\subsection{Sensitivity Studies}

Sensitivity studies were conducted in order to assess the effect of various parameters on live load distribution. The sensitivity studies were conducted using an "average" reinforced concrete T-beam bridge where only one parameter at a time was varied. Although these studies consisted of T-beam bridges, the authors state that the study reveals the parameters to which all types of beam-and-slab bridges are sensitive, and only the numerical values will change. The effects of the following variables were investigated in the sensitivity study: girder spacing, span length, girder stiffness, slab thickness, number of girders, number of design lanes, width of deck overhang, skew, truck configuration, support conditions, and end diaphragms. However, the effects of secondary stiffening elements (such as curbs and parapets), interior diaphragms, and horizontal curvature were not considered in this study. After analyzing the sensitivity of the distribution factors to the parameters listed above, it was determined that some of these variables did not have a significant effect, and therefore the parameters selected to use were girder spacing, span length, girder stiffness, and slab thickness only. 


\subsection{Parametric Study}

A large database of 364 existing bridges from 10 different states was used to determine representative values for the parametric study with the values given in Table 3.1. The database of bridges is further explained in the following sections, along with the description of the parametric study used. Analyses were performed using all possible combinations of these parametric values, and all bridges analyzed had 6 girders, 2 design lanes, a deck overhang of 54 in., and no interior or end diaphragms with a HS20 truck used as the design vehicle.

\subsubsection{Database of State DOT Bridges}

This database used to develop the parametric study consists of 364 existing bridges comprised of 84 prestressed concrete T-beam, 104 concrete I-girder, and 176 steel I-girder bridges. These bridges are from several different geographic regions represented by ten states: Arizona, California, Florida, Maine, Minnesota, New York, Ohio, Oklahoma, Oregon, and Washington. The following data is provided for each bridge in the database; span length, total width, roadway width, skew, number of girders, girder spacing, girder depth, slab thickness, overhang, eccentricity between slab and girder, moment of inertia, cross-sectional area, and date constructed, and can be found in Table 3.2. Table 3.3 also provides the minimum, maximum, and average values of the database, along with histograms of different parameters, are also provided. Histograms of the data provided in the database can be found in Figs. 3.1 through 3.13. 


\subsubsection{Parametric Study Bridges}

The database of bridges describe above was used to determine a range of parameters for a parametric study described in detail in the previous paragraphs with the given values shown in Table 3.1. In summary, the dimensions of the bridges in the parametric study ranged from a girder spacing of 3.5 to $16 \mathrm{ft}$., a span length of 20 to 200 ft., a girder stiffness from 10,000 to 7,000,000 in. ${ }^{4}$, and a slab thickness of 4.4 to $12 \mathrm{in}$. Table 3.4 shows the distribution factors obtained from this parametric study along with sequence number, slab thickness, girder inertia, span length, and girder spacing. These values were then used in the development of a new empirical formula for wheel load distribution.

\subsection{Proposed Equations}

The results from the parametric study were used to derive new empirical equations for wheel load distribution for interior girders. For the distribution of moment with two or more design lanes, four empirical equations with increasing complexity and accuracy were developed. The most accurate of these four equations was modified slightly and adopted into the LRFD Specifications, as shown below

$$
D F=0.15+\left(\frac{S}{3}\right)^{0.6}\left(\frac{S}{L}\right)^{0.2}\left(\frac{I+A e^{2}}{L t_{s}^{3}}\right)^{0.1} \quad \text { (two lanes loaded) }
$$



where $S=$ girder spacing
$L=\quad$ span length
$I=\quad$ transformed moment of inertia of the girder
$A=$ transformed area of the girder
$e=\quad$ distance between the centroid of the slab and the centroid of the girder
$t_{s}=$ slab thickness.

It should be noted that this equation is altered by a factor of two in the LRFD

Specifications to present the distribution factors in terms of lines of wheels instead of

trucks. Although this equation was selected for use because of its enhanced accuracy, the equation does have a negative attribute over the other three proposed equations for two or more design lanes. The equation contains the parameters I, A, and e, which are typically not known prior to design, creating a somewhat iterative procedure that is viewed negatively by bridge engineers.

Equations were also developed for moment with one design lane, end shear with two or more design lanes, end shear with one design lane, and distribution factors for concrete box girders as part of this project. Furthermore, correction factors for skewed supports, continuous spans, and interior shear were also developed. These equations are considered valid for bridges having girder spacing, span length, stiffness, and slab thickness that are within the range of these parameters used in the parametric study. Table 3.5 shows a partial reprint of one of the AASHTO LRFD Specifications load distribution factor tables, which resulted from the NCHRP 12-26 effort; this is for moment in interior beams. 


\subsection{Determination of Accuracy of Proposed Equations}

Nutt et al. (1988) evaluated the accuracy of these equations using two distinct methods. For the first method of evaluation, a database of 30 representative beam-andslab bridges from different states was compiled. The database included T-beam bridges, prestressed concrete I-girder bridges, and steel I-girder bridges that were selected to represent a wide range of bridge parameters. Specifically, the bridges had span lengths of 30 to $200 \mathrm{ft}$., girder spacings of 6 to $13.5 \mathrm{ft}$., girders with moments of inertia from 1,300 to 460,000 in. ${ }^{4}$, and slab thicknesses from 6 to $12 \mathrm{in.} \mathrm{Models} \mathrm{that} \mathrm{represented} \mathrm{these}$ bridges as an eccentrically stiffened plate were created and the resulting distribution factor was determined in a method similar to the parametric study values.

These distribution factors resulting from the analytical models are compared to the empirical equation for two lanes loaded, as shown in Fig. 3.14, where the solid line represents a perfect correlation between the two distribution factors. As shown, the equation well represents the results of the computer analysis and is slightly conservative in most cases, which is desired. Although, there are a few instances where the equation is very unconservative, and the specific details of these bridges is not provided. The standard deviation of the ratio of the distribution factor obtained from the two methods was 0.038 and the authors attribute the differences to the effects of some parameters that are not included in the empirical expression (i.e., torsional inertia, roadway width, etc.) and simplifications made in deriving the expression.

In order to evaluate the proposed equations with a larger database of bridges, a multidimensional space interpolation (MSI) approach was used. This database consisted 
of 304 bridges including T-beam, concrete I-girders, and steel I-girders with the geometric properties given in Table 3.2. The MSI approach is based on simple interpolation techniques that are then extended for the number of variables in a given equation (in this case four variables). This method was shown by the authors to be only slightly less accurate than the analytical results using an eccentrically stiffened plate, while offering the advantage of being less computationally demanding.

The positive correlation between the results from the MSI method and Equation 1 is shown in Fig. 3.15. This figure also shows that there is a relatively low amount of scatter between the two distribution factors, although the scatter does tend to increase with increasing distribution factor. It can also be observed from Fig. 3.15 that when for cases where there is some error between the two methods, the equations tend to err on the conservative side. To summarize, the average ratio of distribution factors from Equation 1 to the distribution factor obtained in the MSI approach was 1.029 with a standard deviation of 0.034 . 
Table 3.1 Parametric values used in development of LRFD distribution factors for beamand-slab bridges

\begin{tabular}{|l|c|c|c|c|c|}
\hline \multicolumn{1}{|c|}{ Parameter } & \multicolumn{5}{|c|}{ Parametric Values } \\
\hline Girder Spacing (ft) & 3.5 & 5.0 & 7.5 & 10.0 & 16.0 \\
\hline Span Length (ft) & 20 & & 64 & 130 & 200 \\
\hline $\mathrm{I}+\mathrm{Ae}^{2}\left(1000\right.$ in $\left.^{4}\right)$ & 10 & 50 & 560 & 3000 & 7000 \\
\hline Slab Thickness (in) & 4.4 & & 7.25 & & 12 \\
\hline
\end{tabular}


Table 3.2. NCHRP $12-26$ database of bridges

\begin{tabular}{|c|c|c|c|c|c|c|c|c|c|c|c|c|c|}
\hline State & $\begin{array}{c}\text { Length } \\
\mathrm{ft} \\
\end{array}$ & $\begin{array}{c}\text { Width } \\
\text { (out-to-out) } \\
\mathrm{ft} \\
\end{array}$ & Skew & $\begin{array}{l}\text { No. of } \\
\text { Girders }\end{array}$ & $\begin{array}{c}\text { Girder } \\
\text { Spacing } \\
\mathrm{ft}\end{array}$ & $\begin{array}{c}\text { Girder } \\
\text { Depth } \\
\mathrm{ft} \\
\end{array}$ & $\begin{array}{c}\text { Slab } \\
\text { Thick. } \\
\text { in } \\
\end{array}$ & $\begin{array}{c}\text { Overhang } \\
\mathrm{ft}\end{array}$ & $\begin{array}{c}\text { Roadway } \\
\text { Width } \\
\mathrm{ft}\end{array}$ & Date & Eccentricity & $\begin{array}{c}\text { Moment of } \\
\text { Inertia } \\
\mathrm{in}^{4} \\
\end{array}$ & $\begin{array}{c}\text { Area } \\
\mathrm{in}^{2} \\
\end{array}$ \\
\hline \multicolumn{14}{|c|}{ Bridge Database from Appendix B of the NCHRP Report 12-26 for Steel I-girder Bridges } \\
\hline Arizona & 67.00 & 34.00 & 20.00 & 4 & 8.83 & 2.92 & 7.00 & 3.75 & 30.00 & 1961 & 21.69 & 11282 & 5.35 \\
\hline Arizona & 73.00 & 34.00 & 20.00 & 4 & 8.83 & 2.92 & 7.00 & 3.75 & 30.00 & 1961 & 21.69 & 11282 & 5.35 \\
\hline Arizona & 77.00 & 34.00 & 20.00 & 4 & 8.83 & 2.92 & 7.00 & 3.75 & 30.00 & 1961 & 21.69 & 11282 & 5.35 \\
\hline Arizona & 86.00 & 34.00 & 20.00 & 4 & 8.83 & 2.92 & 7.00 & 3.75 & 30.00 & 1961 & 21.69 & 11282 & 5.35 \\
\hline Arizona & 53.00 & 35.00 & 30.00 & 4 & 9.33 & 2.75 & 7.00 & 2.25 & 30.00 & 1958 & 20.05 & 6699 & 3.83 \\
\hline Arizona & 67.00 & 35.00 & 30.00 & 4 & 9.33 & 2.75 & 7.00 & 2.25 & 30.00 & 1958 & 20.05 & 6699 & 3.83 \\
\hline Arizona & 46.00 & 35.17 & 9.77 & 4 & 8.83 & 3.00 & 7.50 & 4.25 & 30.00 & 1959 & 21.75 & 9739 & 4.71 \\
\hline Arizona & 79.00 & 35.17 & 9.77 & 4 & 8.83 & 3.00 & 7.50 & 4.25 & 30.00 & 1959 & 21.75 & 9739 & 4.71 \\
\hline Arizona & 44.73 & 35.17 & 20.00 & 4 & 7.00 & 1.33 & 9.00 & - & 22.00 & 1934 & - & - & - \\
\hline Arizona & 30.00 & 34.00 & 0.00 & 5 & 7.50 & 2.00 & 7.75 & 2.00 & 32.00 & 1937 & 15.92 & 2364 & 2.47 \\
\hline Arizona & 40.00 & 34.00 & 0.00 & 5 & 7.50 & 2.00 & 7.75 & 2.00 & 32.00 & 1937 & 15.92 & 2364 & 2.47 \\
\hline California & 61.19 & 48.50 & 30.00 & 8 & 6.50 & 3.66 & 6.25 & 3.00 & 36.00 & 1953 & - & - & - \\
\hline California & 47.00 & 36.00 & 60.54 & 7 & 5.17 & 2.50 & 9.00 & 2.50 & 34.00 & 1936 & 19.41 & 4461 & 3.18 \\
\hline California & 113.17 & 34.00 & 0.00 & 4 & 8.50 & 5.21 & 7.13 & 4.25 & 28.00 & 1967 & 39.78 & 27833 & 6.15 \\
\hline California & 121.68 & 33.00 & 46.96 & 4 & 9.33 & 6.00 & 7.25 & 2.50 & 28.00 & 1959 & - & - & - \\
\hline California & 58.00 & 33.33 & 0.00 & 4 & 9.33 & 4.10 & 7.00 & 2.83 & 28.00 & 1955 & - & - & - \\
\hline California & 50.00 & 33.50 & 30.00 & 5 & 7.50 & 3.75 & 6.50 & 3.38 & 28.00 & 1955 & 21.49 & 12103 & 5.71 \\
\hline California & 130.10 & 33.33 & 64.20 & 5 & 8.33 & 5.42 & 6.38 & 2.50 & 28.00 & 1955 & 36.02 & 51110 & 8.08 \\
\hline California & 92.50 & 44.00 & 63.47 & 6 & 7.31 & 4.56 & 6.75 & 2.83 & 40.00 & 1956 & - & - & - \\
\hline California & 80.66 & 27.50 & 0.00 & 5 & 5.25 & 3.51 & 6.00 & 3.50 & 24.00 & 1949 & 21.00 & 9739 & 4.71 \\
\hline California & 105.20 & 33.66 & 12.57 & 4 & 9.20 & 4.83 & 7.25 & 3.00 & 28.00 & 1958 & - & - & - \\
\hline California & 187.00 & 128.00 & 66.10 & 15 & 8.50 & 6.00 & 7.25 & 3.50 & 122.00 & 1962 & 35.56 & 120145 & 13.95 \\
\hline California & 70.50 & 75.00 & 40.99 & 9 & 8.66 & 3.79 & 6.88 & 2.83 & 69.33 & 1956 & 29.12 & 11500 & 4.78 \\
\hline California & 130.00 & 41.00 & 0.00 & 3 & 15.50 & 7.92 & 9.63 & 5.00 & 39.00 & 1971 & 51.87 & 188585 & 13.00 \\
\hline California & 155.00 & 41.00 & 0.00 & 3 & 15.50 & 7.92 & 9.63 & 5.00 & 39.00 & 1971 & 51.87 & 188585 & 13.00 \\
\hline
\end{tabular}


Table 3.2 cont'd

\begin{tabular}{|c|c|c|c|c|c|c|c|c|c|c|c|c|c|}
\hline State & $\begin{array}{c}\text { Length } \\
\mathrm{ft} \\
\end{array}$ & $\begin{array}{c}\text { Width } \\
\text { (out-to-out) } \\
\mathrm{ft} \\
\end{array}$ & Skew & $\begin{array}{l}\text { No. of } \\
\text { Girders }\end{array}$ & $\begin{array}{c}\text { Girder } \\
\text { Spacing } \\
\mathrm{ft} \\
\end{array}$ & $\begin{array}{c}\text { Girder } \\
\text { Depth } \\
\mathrm{ft} \\
\end{array}$ & $\begin{array}{c}\text { Slab } \\
\text { Thick. } \\
\text { in } \\
\end{array}$ & $\begin{array}{c}\text { Overhang } \\
\mathrm{ft}\end{array}$ & $\begin{array}{c}\text { Roadway } \\
\text { Width } \\
\mathrm{ft}\end{array}$ & Date & Eccentricity & $\begin{array}{c}\text { Moment of } \\
\text { Inertia } \\
\mathrm{in}^{4} \\
\end{array}$ & $\begin{array}{c}\text { Area } \\
\mathrm{in}^{2} \\
\end{array}$ \\
\hline California & 71.00 & 33.92 & 20.39 & 3 & 11.50 & 4.70 & 8.50 & 5.10 & 26.00 & 1947 & - & - & - \\
\hline California & 35.00 & 33.92 & 20.39 & 3 & 11.50 & 4.70 & 8.50 & 5.10 & 26.00 & 1947 & - & - & - \\
\hline California & 68.00 & 26.33 & 0.00 & 4 & 6.66 & 3.75 & 6.75 & 3.33 & 21.00 & 1954 & 21.32 & 14988 & 6.77 \\
\hline California & 60.00 & 35.92 & 2.17 & 4 & 9.50 & 3.58 & 7.13 & 5.10 & 26.00 & 1958 & 21.69 & 17234 & 7.66 \\
\hline California & 116.00 & 33.66 & 0.00 & 4 & 9.00 & 6.50 & 7.00 & 3.33 & 28.00 & 1960 & 42.25 & 68862 & 8.25 \\
\hline California & 140.00 & 33.33 & 40.00 & 3 & 12.00 & 8.00 & 7.75 & 4.66 & 28.00 & 1959 & 48.38 & 230515 & 15.20 \\
\hline California & 51.25 & 57.66 & 0.00 & 9 & 6.50 & 3.25 & 7.00 & 2.83 & 52.00 & 1957 & 20.29 & 5367 & 3.63 \\
\hline California & 51.25 & 33.66 & 0.00 & 5 & 6.50 & 3.25 & 6.50 & 2.83 & 28.00 & 1957 & 20.29 & 5367 & 3.63 \\
\hline California & 100.00 & 36.17 & 0.00 & 4 & 10.00 & 5.70 & 7.25 & 3.08 & 28.00 & 1951 & - & - & - \\
\hline California & 75.25 & 43.92 & 0.00 & 6 & 7.75 & 5.00 & 6.63 & 2.17 & 37.00 & 1955 & 35.34 & 17101 & 4.15 \\
\hline California & 91.25 & 43.92 & 0.00 & 6 & 7.75 & 5.00 & 6.63 & 2.17 & 37.00 & 1955 & 36.13 & 24195 & 5.28 \\
\hline California & 65.50 & 33.33 & 46.78 & 4 & 8.75 & 3.64 & 6.88 & 3.52 & 28.00 & 1958 & 25.77 & 10061 & 5.16 \\
\hline California & 48.77 & 33.33 & 46.78 & 4 & 8.75 & 3.64 & 6.88 & 3.52 & 28.00 & 1958 & 24.01 & 6925 & 3.86 \\
\hline California & 151.13 & 33.33 & 0.00 & 3 & 12.00 & 8.33 & 7.75 & 4.66 & 28.00 & 1958 & 51.38 & 287125 & 16.50 \\
\hline California & 75.00 & 33.33 & 0.00 & 3 & 12.00 & 8.33 & 7.75 & 4.66 & 28.00 & 1958 & 47.06 & 215965 & 6.35 \\
\hline California & 55.00 & 37.92 & 15.52 & 4 & 10.00 & 3.66 & 7.13 & 3.96 & 28.00 & 1958 & 21.51 & 14988 & 6.77 \\
\hline Florida & 142.00 & 84.75 & 0.00 & 10 & 9.25 & 5.50 & 7.50 & 2.00 & 79.25 & 1975 & 37.55 & 59869 & 7.29 \\
\hline Florida & 205.00 & 84.75 & 0.00 & 10 & 9.25 & 5.50 & 7.50 & 2.00 & 79.25 & 1975 & 43.93 & 75951 & 8.94 \\
\hline Florida & 180.00 & 46.75 & 22.92 & 6 & 8.20 & 4.67 & 7.00 & 2.11 & 44.00 & 1980 & 41.25 & 43570 & 7.35 \\
\hline Florida & 43.00 & 30.67 & 11.55 & 10 & 3.00 & 2.50 & 10.00 & 1.00 & 28.00 & 1966 & 20.06 & 8826 & 5.59 \\
\hline Florida & 49.00 & 30.67 & 11.55 & 10 & 3.00 & 2.50 & 10.00 & 1.00 & 28.00 & 1966 & 20.06 & 8826 & 5.59 \\
\hline Maine & 20.00 & 23.00 & 0.00 & 5 & 5.00 & 1.50 & 6.50 & 1.08 & 22.00 & 1940 & 11.50 & 801 & 1.47 \\
\hline Maine & 45.00 & 25.00 & 20.00 & 5 & 5.25 & 2.25 & 6.50 & 1.50 & 22.00 & 1940 & 16.79 & 3604 & 3.01 \\
\hline Maine & 75.00 & 25.00 & 20.00 & 5 & 5.25 & 3.33 & 6.50 & 1.50 & 22.00 & 1940 & - & - & - \\
\hline Maine & 50.00 & 35.00 & 0.00 & 5 & 7.92 & 2.75 & 7.50 & 1.17 & 30.00 & 1960 & 22.61 & 8641 & 4.28 \\
\hline Maine & 60.00 & 25.00 & 0.00 & 5 & 5.00 & 3.00 & 7.00 & 2.00 & 22.00 & 1935 & 21.42 & 9012 & 4.42 \\
\hline
\end{tabular}


Table 3.2 cont'd

\begin{tabular}{|c|c|c|c|c|c|c|c|c|c|c|c|c|c|}
\hline State & $\begin{array}{c}\text { Length } \\
\mathrm{ft}\end{array}$ & $\begin{array}{c}\text { Width } \\
\text { (out-to-out) } \\
\mathrm{ft}\end{array}$ & Skew & $\begin{array}{l}\text { No. of } \\
\text { Girders }\end{array}$ & $\begin{array}{c}\text { Girder } \\
\text { Spacing } \\
\mathrm{ft}\end{array}$ & $\begin{array}{l}\text { Girder } \\
\text { Depth } \\
\mathrm{ft}\end{array}$ & $\begin{array}{c}\text { Slab } \\
\text { Thick. } \\
\text { in }\end{array}$ & $\begin{array}{c}\text { Overhang } \\
\mathrm{ft}\end{array}$ & $\begin{array}{c}\text { Roadway } \\
\text { Width } \\
\mathrm{ft}\end{array}$ & Date & Eccentricity & $\begin{array}{c}\text { Moment of } \\
\text { Inertia } \\
\mathrm{in}^{4}\end{array}$ & $\begin{array}{c}\text { Area } \\
\text { in }^{2}\end{array}$ \\
\hline Maine & 75.00 & 37.50 & 0.00 & 5 & 8.25 & 3.00 & 6.00 & 2.00 & 28.00 & 1956 & 25.60 & 16856 & 7.40 \\
\hline Maine & 76.00 & 33.00 & 45.00 & 5 & 7.25 & 3.00 & 6.50 & 1.33 & 28.00 & 1961 & 25.02 & 15903 & 7.02 \\
\hline Maine & 90.00 & 36.67 & 0.00 & 5 & 8.00 & 3.00 & 9.00 & 1.42 & 32.00 & 1979 & 27.33 & 18554 & 8.06 \\
\hline Maine & 96.52 & 27.75 & 10.00 & 5 & 5.75 & 3.00 & 6.50 & 2.00 & 24.00 & 1956 & 26.66 & 17780 & 7.81 \\
\hline Maine & 95.00 & 42.67 & 30.00 & 6 & 7.33 & 3.50 & 7.50 & 2.50 & 38.83 & 1970 & 28.38 & 20700 & 5.74 \\
\hline Maine & 110.00 & 31.67 & 0.00 & 4 & 8.50 & 4.00 & 8.50 & 2.33 & 28.00 & 1971 & 32.94 & 29835 & 6.92 \\
\hline Maine & 75.00 & 29.00 & 0.00 & 5 & 6.00 & 2.77 & 5.75 & 2.00 & 24.00 & 1963 & 19.38 & 11048 & 5.88 \\
\hline Maine & 20.50 & 26.00 & 0.00 & 12 & 2.17 & 1.00 & 7.50 & 0.50 & 22.00 & 1957 & 9.80 & 234 & 0.91 \\
\hline Maine & 44.00 & 42.58 & 13.50 & 6 & 7.97 & 1.25 & 7.50 & 1.42 & 39.00 & 1965 & 17.29 & 3604 & 3.00 \\
\hline Maine & 70.00 & 42.67 & 0.00 & 6 & 7.50 & 3.00 & 8.50 & 1.92 & 39.00 & 1977 & 22.03 & 7796 & 3.97 \\
\hline Maine & 100.00 & 33.67 & 0.00 & 5 & 7.00 & 3.00 & 8.00 & 1.92 & 29.83 & 1973 & 23.71 & 10460 & 4.90 \\
\hline Maine & 201.00 & 67.17 & 10.00 & 8 & 8.67 & 9.50 & 8.50 & 2.33 & 54.00 & 1977 & 38.82 & 41776 & 7.16 \\
\hline Maine & 161.00 & 67.17 & 10.00 & 8 & 8.67 & 9.50 & 8.50 & 2.33 & 55.00 & 1977 & 40.56 & 44936 & 7.69 \\
\hline Minnesota & 40.00 & 28.33 & 30.00 & 13 & 2.29 & 1.50 & 10.00 & 0.00 & 26.33 & 1938 & 11.27 & 890 & 1.62 \\
\hline Minnesota & 56.25 & 33.33 & 0.00 & 7 & 5.33 & 2.50 & 7.25 & 0.17 & 30.00 & 1920 & 18.78 & 5753 & 3.88 \\
\hline Minnesota & 28.00 & 22.00 & 0.00 & 9 & 2.58 & 1.25 & 6.50 & 0.25 & 19.00 & 1926 & 11.25 & 516 & 1.12 \\
\hline Minnesota & 54.25 & 30.67 & 45.00 & 12 & 2.62 & 2.17 & 7.25 & 0.33 & 27.00 & 1931 & 15.56 & 2096 & 2.24 \\
\hline Minnesota & 43.00 & 30.33 & 0.00 & 7 & 4.83 & 2.25 & 7.00 & 0.33 & 27.00 & 1935 & 17.04 & 3267 & 3 \\
\hline Minnesota & 51.00 & 33.17 & 0.00 & 7 & 5.25 & 2.50 & 6.50 & 0.33 & 30.00 & 1940 & 18.15 & 4461 & 3.18 \\
\hline Minnesota & 50.00 & 34.50 & 0.00 & 5 & 7.00 & 2.75 & 6.00 & 2.58 & 30.00 & 1950 & 19.55 & 6699 & 3.83 \\
\hline Minnesota & 68.00 & 34.00 & 0.00 & 5 & 7.00 & 3.00 & 6.00 & 2.54 & 30.00 & 1955 & 20.92 & 9012 & 4.42 \\
\hline Minnesota & 65.00 & 34.50 & 0.00 & 5 & 7.00 & 3.00 & 6.00 & 2.58 & 30.00 & 1950 & 20.92 & 9012 & 4.42 \\
\hline Minnesota & 121.50 & 64.25 & 0.00 & 8 & 8.08 & 3.67 & 9.00 & 3.33 & 46.83 & 1978 & 26.5 & 41824 & 10.98 \\
\hline Minnesota & 47.50 & 50.33 & 60.00 & 6 & 8.83 & 2.50 & 9.00 & 2.58 & 46.50 & 1977 & 19.32 & 3989 & 2.91 \\
\hline Minnesota & 65.00 & 50.33 & 60.00 & 6 & 8.83 & 2.50 & 9.00 & 2.58 & 46.50 & 1977 & 19.32 & 3989 & 2.91 \\
\hline Minnesota & 98.00 & 45.08 & 0.00 & 5 & 9.83 & 4.83 & 8.25 & 2.67 & 36.00 & 1973 & 35.81 & 29122 & 5.35 \\
\hline
\end{tabular}


Table 3.2 cont'd

\begin{tabular}{|c|c|c|c|c|c|c|c|c|c|c|c|c|c|}
\hline & $\begin{array}{c}\text { Length } \\
\mathrm{ft}\end{array}$ & $\begin{array}{c}\text { Width } \\
\text { (out-to-out) } \\
\mathrm{ft}\end{array}$ & Skew & $\begin{array}{l}\text { No. of } \\
\text { Girders }\end{array}$ & $\begin{array}{c}\text { Girder } \\
\text { Spacing } \\
\mathrm{ft}\end{array}$ & $\begin{array}{c}\text { Girder } \\
\text { Depth } \\
\mathrm{ft}\end{array}$ & $\begin{array}{c}\text { Slab } \\
\text { Thick. } \\
\text { in }\end{array}$ & $\begin{array}{c}\text { Overhang } \\
\mathrm{ft}\end{array}$ & $\begin{array}{c}\text { Roadway } \\
\text { Width } \\
\mathrm{ft}\end{array}$ & Date & Eccentricity & $\begin{array}{c}\text { Moment of } \\
\text { Inertia } \\
\mathrm{in}^{4}\end{array}$ & Area \\
\hline Minnesota & 125.00 & 49.00 & 0.00 & 5 & 9.83 & 4.83 & 8.25 & 2.67 & 36.00 & 1973 & 34.73 & 27508 & 5.15 \\
\hline Minnesota & 69.83 & 60.83 & 56.87 & 7 & 8.92 & 3.50 & 6.50 & 3.00 & 52.00 & 1964 & 26.50 & 11639.00 & 3.65 \\
\hline Minnesota & 109.50 & 60.83 & 56.87 & 7 & 8.92 & 3.50 & 6.50 & 3.00 & 52.00 & 1964 & 29.62 & 13704.00 & 4.25 \\
\hline Minnesota & 69.83 & 60.83 & 56.87 & 7 & 8.92 & 3.50 & 6.50 & 3.00 & 52.00 & 1964 & 26.50 & 11639.00 & 3.65 \\
\hline Minnesota & 89.00 & 35.17 & 0.00 & 4 & 9.33 & 3.00 & 6.75 & 3.00 & 30 & 1962 & 25.13 & 10629.00 & 4.28 \\
\hline New York & 105.00 & 47.71 & 0.00 & 6 & 8.67 & 3.00 & 12.01 & 1.69 & 36.00 & 1955 & 29.56 & 15587 & 6.91 \\
\hline New York & 130.00 & 47.71 & 0.00 & 6 & 8.67 & 3.00 & 12.01 & 1.69 & 36.00 & 1955 & 32.80 & 19181 & 8.66 \\
\hline New York & 100.73 & 47.00 & 0.00 & 8 & 6.60 & 1.50 & 7.00 & 2.00 & 33.00 & 1961 & 35.35 & 43005 & 8.13 \\
\hline New York & 44.52 & 80.00 & 8.29 & 13 & 6.58 & 2.00 & 7.00 & 0.00 & 50.00 & 1945 & 15.88 & 5110 & 4.70 \\
\hline New York & 96.52 & 57.83 & 27.93 & 8 & 7.40 & 1.33 & 7.50 & 2.00 & 55.00 & 1968 & 31.73 & 25933 & 6.98 \\
\hline New York & 116.49 & 59.00 & 51.83 & 8 & 7.75 & 1.67 & 7.50 & 2.00 & 50.50 & 1968 & 32.16 & 56282 & 10.30 \\
\hline New York & 110.02 & 81.00 & 51.83 & 11 & 7.60 & 1.67 & 7.50 & 2.00 & 74.50 & 1968 & 32.88 & 44028 & 8.55 \\
\hline New York & 87.30 & 31.33 & 0.00 & 5 & 7.00 & 3.00 & 8.50 & 1.21 & 28.00 & 1970 & 24.53 & 17871 & 7.77 \\
\hline New York & 71.72 & 57.00 & 10.64 & 7 & 8.57 & 3.00 & 7.00 & 2.00 & 50.00 & 1962 & 26.22 & 17002 & 7.46 \\
\hline New York & 57.00 & 56.00 & 46.83 & 8 & 7.33 & 2.75 & 7.50 & 1.89 & 48.00 & 1967 & 22.90 & 8369 & 4.53 \\
\hline New York & 86.33 & 56.00 & 46.83 & 8 & 7.33 & 2.75 & 7.50 & 1.89 & 48.00 & 1967 & 24.52 & 18518 & 9.18 \\
\hline New York & 76.83 & 56.00 & 46.83 & 8 & 7.33 & 2.75 & 7.50 & 1.89 & 48.00 & 1967 & 24.06 & 14860 & 7.58 \\
\hline New York & 31.92 & 33.54 & 28.00 & 5 & 7.61 & 2.75 & 7.00 & 2.42 & 27.00 & 1960 & 20.05 & 6699 & 3.83 \\
\hline New York & 58.58 & 33.54 & 17.00 & 5 & 7.61 & 2.75 & 7.00 & 2.42 & 27.00 & 1960 & 23.87 & 10949 & 5.65 \\
\hline New York & 62.97 & 34.25 & 52.10 & 6 & 5.57 & 3.00 & 6.50 & 2.50 & 26.00 & 19-- & 21.28 & 16092 & 7.20 \\
\hline New York & 57.39 & 34.25 & 38.89 & 6 & 5.57 & 2.75 & 6.50 & 2.50 & 26.00 & 19-- & 21.28 & 8773 & 4.68 \\
\hline New York & 37.40 & 34.25 & 33.86 & 6 & 5.57 & 2.50 & 6.50 & 2.50 & 26.00 & 19-- & 18.16 & 4461 & 3.18 \\
\hline New York & 51.90 & 70.00 & 6.43 & 12 & 5.55 & 3.00 & 7.50 & 0.67 & 50.00 & 19-- & 21.83 & 10470 & 5.00 \\
\hline New York & 83.60 & 63.00 & 13.00 & 8 & 8.23 & 4.00 & 7.50 & 2.83 & 40.00 & 1950 & 34.25 & 33754 & 5.25 \\
\hline New York & 45.00 & 32.87 & 35.17 & 5 & 7.00 & 2.75 & 7.00 & 2.08 & 28.00 & 19-- & 20.16 & 7442 & 4.15 \\
\hline New York & 92.75 & 32.87 & 35.17 & 5 & 7.00 & 3.00 & 7.00 & 2.08 & 28.00 & 19-- & 25.48 & 20035 & 8.67 \\
\hline
\end{tabular}


Table 3.2 cont'd

\begin{tabular}{|c|c|c|c|c|c|c|c|c|c|c|c|c|c|}
\hline State & $\begin{array}{c}\text { Length } \\
\mathrm{ft}\end{array}$ & $\begin{array}{c}\text { Width } \\
\text { (out-to-out) } \\
\mathrm{ft}\end{array}$ & Skew & $\begin{array}{l}\text { No. of } \\
\text { Girders }\end{array}$ & $\begin{array}{c}\text { Girder } \\
\text { Spacing } \\
\mathrm{ft}\end{array}$ & $\begin{array}{c}\text { Girder } \\
\text { Depth } \\
\mathrm{ft}\end{array}$ & $\begin{array}{c}\text { Slab } \\
\text { Thick. } \\
\text { in }\end{array}$ & \begin{tabular}{|c|} 
Overhang \\
$\mathrm{ft}$
\end{tabular} & $\begin{array}{c}\text { Roadway } \\
\text { Width } \\
\mathrm{ft}\end{array}$ & Date & Eccentricity & $\begin{array}{c}\text { Moment of } \\
\text { Inertia } \\
\text { in }^{4}\end{array}$ & $\begin{array}{l}\text { Area } \\
\text { in }^{2} \\
\end{array}$ \\
\hline New York & 50.50 & 32.87 & 35.17 & 5 & 7.00 & 2.75 & 7.00 & 2.08 & 28.00 & 19-- & 20.16 & 7442 & 4.15 \\
\hline New York & 39.08 & 53.50 & 2.06 & 8 & 6.83 & 2.50 & 7.00 & 2.25 & 36.00 & 1955 & 18.41 & 4461 & 3.18 \\
\hline New York & 84.58 & 53.50 & 2.06 & 8 & 6.83 & 3.00 & 7.00 & 2.25 & 36.00 & 1955 & 23.44 & 14988 & 6.77 \\
\hline New York & 48.75 & 71.00 & 16.35 & 8 & 9.50 & 3.00 & 7.50 & 2.67 & 60.00 & 1955 & 26.38 & 10967 & 5.29 \\
\hline New York & 80.25 & 71.00 & 16.35 & 8 & 9.50 & 3.00 & 7.50 & 2.67 & 60.00 & 1955 & 26.72 & 21353 & 9.27 \\
\hline New York & 41.25 & 47.77 & 7.16 & 6 & 8.79 & 2.75 & 7.25 & 2.00 & 36.00 & 1957 & 21.77 & 7721 & 4.23 \\
\hline New York & 75.67 & 47.77 & 7.16 & 6 & 8.79 & 3.00 & 7.25 & 2.00 & 36.00 & 1957 & 25.71 & 20252 & 8.70 \\
\hline Ohio & 30.07 & 35.67 & 8.42 & 5 & 7.25 & 2 & 7.5 & 2.83 & 32.5 & 1953 & 15.25 & 2987 & 2.94 \\
\hline Ohio & 38.92 & 35.67 & 8.42 & 5 & 7.25 & 2.50 & 7.50 & 2.83 & 32.50 & 1953 & 18.83 & 5347 & 3.65 \\
\hline Ohio & 137.00 & 57.50 & 61.55 & 5 & 12.75 & 7.38 & 8.19 & 2.17 & 48.00 & 1962 & 48.97 & 223500 & 13.83 \\
\hline Ohio & 55.00 & 44.00 & 12.00 & 6 & 7.87 & 2.75 & 8.25 & 1.89 & 36.00 & 1985 & 20.68 & 6699 & 3.83 \\
\hline Ohio & 39.00 & 28.50 & 0.00 & 5 & 5.75 & 2.25 & 6.75 & 2.50 & 24.00 & 1941 & 16.83 & 3267 & 2.77 \\
\hline Ohio & 162.00 & 56.00 & 58.93 & 6 & 10.17 & 11.71 & 9.00 & 2.00 & 51.00 & 1968 & 66.88 & 409716 & 14.00 \\
\hline Ohio & 43.00 & 28.00 & 0.00 & 4 & 7.50 & 2.50 & 8.00 & 2.75 & 28.00 & 1985 & 18.82 & 3989 & 2.91 \\
\hline Ohio & 12.00 & 30.00 & 17.50 & 11 & 3.00 & 0.83 & 4.42 & 0.42 & 30.00 & 19-- & 0.00 & 157 & 0.85 \\
\hline Ohio & 75.00 & 75.00 & 56.84 & 12 & 6.75 & 3.00 & 7.75 & 0.67 & 67.00 & 1957 & 22.13 & 18819 & 8.23 \\
\hline Ohio & 63.00 & 44.45 & 8.31 & 6 & 7.95 & 3.00 & 8.75 & 2.00 & 39.74 & 1964 & 22.41 & 16092 & 7.20 \\
\hline Ohio & 42.50 & 37.67 & 0.00 & 12 & 3.21 & 2.00 & 4.42 & 0.83 & 36.00 & 1960 & 0.00 & 2096 & 2.24 \\
\hline Ohio & 52.00 & 72.00 & 20.06 & 9 & 8.56 & 3.00 & 8.00 & 1.25 & 68.50 & 1968 & 21.92 & 9012 & 4.42 \\
\hline Ohio & 72.00 & 72.00 & 20.06 & 9 & 8.56 & 3.00 & 8.00 & 1.25 & 68.50 & 1968 & 22.08 & 10470 & 5.00 \\
\hline Ohio & 27.00 & 29.50 & 0.00 & 5 & 5.75 & 1.75 & 7.25 & 2.75 & 24.00 & 1953 & 14.13 & 1327 & 1.82 \\
\hline Ohio & 65.54 & 29.50 & 0.00 & 5 & 5.75 & 1.75 & 7.25 & 2.75 & 24.00 & 1953 & 20.18 & 6699 & 3.83 \\
\hline Ohio & 63.50 & 34.33 & 24.59 & 4 & 9.00 & 3.00 & 7.75 & 3.17 & 24.00 & 1964 & 21.80 & 9012 & 4.42 \\
\hline Ohio & 45.00 & 34.33 & 24.59 & 4 & 9.00 & 3.00 & 7.75 & 3.17 & 24.00 & 1964 & 21.80 & 9012 & 4.42 \\
\hline Ohio & 44.00 & 40.00 & 25.00 & 5 & 8.87 & 2.75 & 7.50 & 2.00 & 40.00 & 1955 & 20.41 & 7442 & 4.15 \\
\hline Ohio & 55.00 & 40.00 & 25.00 & 5 & 8.87 & 2.75 & 7.50 & 2.00 & 40.00 & 1955 & 20.41 & 7442 & 4.15 \\
\hline
\end{tabular}


Table 3.2 cont'd

\begin{tabular}{|c|c|c|c|c|c|c|c|c|c|c|c|c|c|}
\hline State & $\begin{array}{c}\text { Length } \\
\mathrm{ft}\end{array}$ & $\begin{array}{c}\text { Width } \\
\text { (out-to-out) } \\
\mathrm{ft}\end{array}$ & Skew & $\begin{array}{l}\text { No. of } \\
\text { Girders }\end{array}$ & $\begin{array}{c}\text { Girder } \\
\text { Spacing } \\
\mathrm{ft}\end{array}$ & $\begin{array}{c}\text { Girder } \\
\text { Depth } \\
\mathrm{ft}\end{array}$ & $\begin{array}{c}\text { Slab } \\
\text { Thick. } \\
\text { in }\end{array}$ & \begin{tabular}{|c|} 
Overhang \\
$\mathrm{ft}$
\end{tabular} & $\begin{array}{c}\text { Roadway } \\
\text { Width } \\
\mathrm{ft}\end{array}$ & Date & Eccentricity & $\begin{array}{c}\text { Moment of } \\
\text { Inertia } \\
\text { in }^{4}\end{array}$ & $\begin{array}{l}\text { Area } \\
\text { in }^{2}\end{array}$ \\
\hline Ohio & 62.56 & 63.50 & 2.50 & 8 & 8.83 & 3.00 & 8.75 & 1.58 & 56.75 & 1972 & 22.32 & 14988 & 6.77 \\
\hline Ohio & 65.56 & 59.50 & 2.50 & 8 & 8.83 & 3.00 & 8.75 & 1.58 & 56.75 & 1972 & 22.49 & 12103 & 5.71 \\
\hline Ohio & 64.00 & 30.00 & 2.50 & 4 & 8.83 & 3.00 & 8.75 & 1.58 & 26.50 & 19-- & 22.32 & 14988 & 6.77 \\
\hline Ohio & 74.50 & 58.00 & 0.00 & 7 & 8.33 & 3.00 & 8.50 & 3.50 & 50.00 & 1965 & 22.19 & 14988 & 6.77 \\
\hline Ohio & 66.25 & 58.00 & 0.00 & 7 & 8.33 & 3.00 & 8.50 & 3.50 & 50.00 & 1965 & 22.25 & 9739 & 4.71 \\
\hline Ohio & 80.00 & 58.00 & 0.00 & 7 & 8.33 & 3.00 & 8.50 & 3.50 & 50.00 & 1965 & 22.49 & 12103 & 5.71 \\
\hline Ohio & 93.12 & 58.00 & 0.00 & 7 & 8.33 & 3.00 & 8.50 & 3.50 & 50.00 & 1965 & 22.28 & 16092 & 7.30 \\
\hline Ohio & 56.00 & 58.00 & 0.00 & 7 & 8.33 & 3.00 & 8.50 & 3.50 & 50.00 & 1965 & 22.25 & 9739 & 4.71 \\
\hline Ohio & 70.00 & 44.00 & 30.00 & 6 & 7.87 & 3.00 & 7.75 & 1.79 & 44.00 & 1963 & 21.66 & 7796 & 3.97 \\
\hline Ohio & 56.00 & 44.00 & 30.00 & 6 & 7.87 & 3.00 & 7.75 & 1.79 & 44.00 & 1963 & 21.66 & 7796 & 3.97 \\
\hline Ohio & 80.00 & 55.17 & 10.26 & 7 & 8.25 & 3.00 & 9.00 & 2.83 & 49.83 & 1959 & 22.53 & 16092 & 7.20 \\
\hline Ohio & 48.00 & 55.17 & 10.26 & 7 & 8.25 & 3.00 & 9.00 & 2.83 & 49.83 & 1959 & 22.50 & 9739 & 4.71 \\
\hline Ohio & 80.00 & 43.17 & 10.26 & 7 & 8.25 & 3.00 & 9.00 & 2.83 & 37.83 & 1959 & 22.44 & 14988 & 6.77 \\
\hline Ohio & 48.00 & 43.17 & 10.26 & 7 & 8.25 & 3.00 & 9.00 & 2.83 & 37.83 & 1959 & 22.42 & 9012 & 4.42 \\
\hline Oklahoma & 36.00 & 22.50 & 0.00 & 5 & 5.25 & 2.17 & 8.75 & 0.50 & 20.00 & 1928 & 17.38 & 3000 & 2.70 \\
\hline Oklahoma & 34.75 & 22.50 & 0.00 & 5 & 5.25 & 2.17 & 8.75 & 0.50 & 20.00 & 1928 & 17.38 & 3000 & 2.70 \\
\hline Oklahoma & 50.00 & 24.33 & 0.00 & 5 & 5.17 & 2.75 & 6.50 & 1.58 & 22.00 & 1938 & 20.55 & 6699 & 3.83 \\
\hline Oklahoma & 30.00 & 27.00 & 0.00 & 6 & 4.50 & 1.75 & 6.00 & 2.00 & 24.00 & 1935 & 14.38 & 1327 & 1.82 \\
\hline Oklahoma & 34.35 & 24.33 & 45.00 & 5 & 5.17 & 2.25 & 6.50 & 1.58 & 22.00 & 1931 & 17.35 & 2825 & 2.47 \\
\hline Oklahoma & 36.00 & 24.33 & 45.00 & 5 & 5.17 & 2.25 & 6.50 & 1.58 & 22.00 & 1931 & 17.35 & 2825 & 2.47 \\
\hline Oklahoma & 31.67 & 28.00 & 30.00 & 6 & 4.92 & 2.00 & 7.50 & 1.21 & 26.00 & 1947 & 15.80 & 2364 & 2.47 \\
\hline Oklahoma & 40.00 & 28.00 & 30.00 & 6 & 4.92 & 2.25 & 7.50 & 1.21 & 26.00 & 1947 & 17.21 & 3267 & 2.77 \\
\hline Oklahoma & 61.00 & 29.00 & 0.00 & 6 & 4.92 & 2.75 & 7.50 & 1.21 & 24.00 & 1936 & 20.41 & 7442 & 4.15 \\
\hline Oklahoma & 41.25 & 31.00 & 0.00 & 5 & 6.58 & 2.50 & 7.50 & 1.83 & 28.00 & 1956 & 20.30 & 6699 & 3.83 \\
\hline Oklahoma & 59.83 & 31.00 & 0.00 & 5 & 6.58 & 3.17 & 7.50 & 1.83 & 28.00 & 1956 & 21.83 & 10470 & 5.00 \\
\hline Oklahoma & 32.67 & 27.00 & 45.00 & 6 & 4.50 & 1.75 & 7.50 & 2.00 & 24.00 & 1935 & 15.80 & 2364 & 2.47 \\
\hline
\end{tabular}


Table 3.2 cont'd

\begin{tabular}{|c|c|c|c|c|c|c|c|c|c|c|c|c|c|}
\hline State & $\begin{array}{c}\text { Length } \\
\mathrm{ft} \\
\end{array}$ & $\begin{array}{c}\text { Width } \\
\text { (out-to-out) } \\
\mathrm{ft} \\
\end{array}$ & Skew & $\begin{array}{l}\text { No. of } \\
\text { Girders }\end{array}$ & $\begin{array}{c}\text { Girder } \\
\text { Spacing } \\
\mathrm{ft} \\
\end{array}$ & $\begin{array}{c}\text { Girder } \\
\text { Depth } \\
\mathrm{ft} \\
\end{array}$ & $\begin{array}{c}\text { Slab } \\
\text { Thick. } \\
\text { in } \\
\end{array}$ & $\begin{array}{c}\text { Overhang } \\
\mathrm{ft}\end{array}$ & $\begin{array}{c}\text { Roadway } \\
\text { Width } \\
\mathrm{ft} \\
\end{array}$ & Date & Eccentricity & $\begin{array}{c}\text { Moment of } \\
\text { Inertia } \\
\mathrm{in}^{4} \\
\end{array}$ & $\begin{array}{l}\text { Area } \\
\mathrm{in}^{2} \\
\end{array}$ \\
\hline Oklahoma & 58.92 & 27.00 & 45.00 & 6 & 4.50 & 3.00 & 7.50 & 2.00 & 24.00 & 1935 & 21.83 & 10470 & 5.00 \\
\hline Oklahoma & 37.17 & 22.50 & 0.00 & 5 & 5.25 & 2.17 & 8.75 & 0.33 & 20.00 & 1927 & 16.43 & 2364 & 2.47 \\
\hline Oklahoma & 59.58 & 28.50 & 0.00 & - & - & - & - & - & 26.00 & 1953 & - & - & - \\
\hline Oklahoma & 31.46 & 28.50 & 0.00 & - & - & - & - & - & 26.00 & 1953 & - & - & - \\
\hline Oklahoma & 38.75 & 31.00 & 0.00 & 5 & 6.58 & 2.50 & 7.50 & 1.83 & 28.00 & 1956 & 23.66 & 4461 & 3.18 \\
\hline Oklahoma & 44.00 & 26.33 & 30.00 & 6 & 4.92 & 2.25 & 7.50 & 1.21 & 24.00 & 1935 & 17.29 & 3604 & 3.00 \\
\hline Oklahoma & 45.71 & 26.33 & 30.00 & 6 & 4.92 & 2.25 & 7.50 & 1.21 & 24.00 & 1935 & 17.21 & 3267 & 2.77 \\
\hline Oklahoma & 31.25 & 26.50 & 0.00 & 5 & 5.67 & 2.00 & 8.00 & 1.29 & 24.00 & 1932 & 15.19 & 2096 & 2.24 \\
\hline Oklahoma & 30.00 & 26.50 & 0.00 & 5 & 5.67 & 2.00 & 8.00 & 1.29 & 24.00 & 1932 & - & - & - \\
\hline Oklahoma & 26.00 & 43.00 & 0.00 & 9 & 5.25 & - & 5.00 & 2.50 & 40.00 & 1955 & - & - & - \\
\hline Oklahoma & 72.00 & 31.00 & 35.83 & 5 & 6.58 & 2.75 & 6.00 & 1.83 & 28.00 & 1954 & 19.55 & 6699 & 3.83 \\
\hline Oklahoma & 81.50 & 31.00 & 35.83 & 5 & 6.58 & 2.75 & 6.00 & 1.83 & 28.00 & 1954 & 19.55 & 6699 & 3.83 \\
\hline Oklahoma & 125.00 & 41.00 & 0.00 & 4 & 11.00 & 5.00 & 10.00 & 3.25 & 38.00 & 1983 & 40.99 & 51463 & 8.25 \\
\hline Oklahoma & 160.00 & 41.00 & 0.00 & 4 & 11.00 & 5.00 & 10.00 & 3.25 & 38.00 & 1983 & 40.99 & 51463 & 8.25 \\
\hline Oregon & 140.00 & 59.00 & 0.00 & 6 & 13.50 & 8.81 & 6.50 & 2.00 & 58.00 & 1951 & 55.75 & 203546 & 10.93 \\
\hline Oregon & 113.00 & 76.00 & 0.00 & 6 & 9.00 & 4.00 & 7.00 & 6.00 & 70.00 & 1962 & 34.64 & 27429 & 6.13 \\
\hline Oregon & 142.00 & 76.00 & 0.00 & 6 & 9.00 & 4.00 & 7.00 & 6.00 & 70.00 & 1962 & 34.64 & 27429 & 6.13 \\
\hline Oregon & 64.00 & 34.83 & 30.00 & 4 & 11.00 & 4.50 & 7.50 & 0.90 & 32.00 & 1969 & 35.24 & 39977 & 5.80 \\
\hline Oregon & 152.50 & 34.83 & 30.00 & 4 & 11.00 & 4.50 & 7.50 & 0.90 & 32.00 & 1969 & 37.79 & 45716 & 6.45 \\
\hline Oregon & 53.00 & 34.83 & 30.00 & 4 & 11.00 & 4.50 & 7.50 & 0.90 & 32.00 & 1969 & 35.24 & 39977 & 5.80 \\
\hline Oregon & 52.50 & 56.00 & 0.00 & - & 2.00 & 1.50 & 5.00 & 1.50 & 40.00 & 1960 & 10.95 & 1322 & 2.36 \\
\hline \multicolumn{14}{|c|}{ Bridge Database from Appendix B of the NCHRP Report 12-26 for Concrete T-beam Bridges } \\
\hline Arizona & 68.00 & 32.00 & 0.00 & 4 & 8.00 & 5.17 & 6.75 & 4.12 & 29.75 & 1973 & 34.38 & 417074 & 130.20 \\
\hline Arizona & 71.00 & 32.00 & 0.00 & 4 & 8.00 & 5.17 & 6.75 & 4.12 & 29.75 & 1973 & 34.38 & 417074 & 130.20 \\
\hline California & 31.21 & 16.00 & 33.75 & 3 & 7.35 & 2.33 & 9.00 & 0.58 & 14.66 & 1926 & 13.56 & 8437 & 30.80 \\
\hline California & 31.00 & 30.10 & 27.50 & 6 & 5.75 & 2.33 & 6.50 & 0.00 & 24.00 & 1945 & 14.00 & 14079 & 26.55 \\
\hline
\end{tabular}


Table 3.2 cont'd

\begin{tabular}{|c|c|c|c|c|c|c|c|c|c|c|c|c|c|}
\hline State & $\begin{array}{c}\text { Length } \\
\mathrm{ft}\end{array}$ & $\begin{array}{c}\text { Width } \\
\text { (out-to-out) } \\
\mathrm{ft}\end{array}$ & Skew & $\begin{array}{l}\text { No. of } \\
\text { Girders }\end{array}$ & $\begin{array}{c}\text { Girder } \\
\text { Spacing } \\
\mathrm{ft}\end{array}$ & $\begin{array}{c}\text { Girder } \\
\text { Depth } \\
\mathrm{ft}\end{array}$ & $\begin{array}{c}\text { Slab } \\
\text { Thick. } \\
\text { in }\end{array}$ & $\begin{array}{c}\text { Overhang } \\
\mathrm{ft}\end{array}$ & $\begin{array}{c}\text { Roadway } \\
\text { Width } \\
\mathrm{ft}\end{array}$ & Date & Eccentricity & $\begin{array}{c}\text { Moment of } \\
\text { Inertia } \\
\mathrm{in}^{4}\end{array}$ & $\begin{array}{c}\text { Area } \\
\text { in }^{2}\end{array}$ \\
\hline California & 31.00 & 30.10 & 27.50 & 6 & 5.75 & 2.33 & 6.50 & 0.00 & 24.00 & 1945 & 14.00 & 14079 & 26.55 \\
\hline California & 31.00 & 27.17 & 0.00 & 4 & 7.60 & 3.00 & 9.00 & 1.63 & 24.00 & 1929 & 18.00 & 24600 & 40.50 \\
\hline California & 30.00 & 53.00 & 4.00 & 7 & 7.92 & 3.50 & 6.25 & 2.57 & 51.00 & 1966 & 21.00 & 53300 & 50.00 \\
\hline California & 29.17 & 39.00 & 0.00 & 5 & 8.33 & 3.50 & 6.50 & 2.25 & 37.00 & 1966 & 21.00 & 53300 & 50.00 \\
\hline California & 30.00 & 39.00 & 0.00 & 5 & 8.33 & 3.50 & 6.50 & 2.25 & 37.00 & 1966 & 21.00 & 53300 & 50.00 \\
\hline California & 55.00 & 53.00 & 4.00 & 7 & 7.92 & 3.50 & 6.25 & 2.57 & 51.00 & 1966 & 21.00 & 53300 & 50.00 \\
\hline California & 60.00 & 92.00 & 45.00 & 12 & 7.83 & 4.00 & 6.25 & 2.17 & 90.00 & 1967 & 24.00 & 78837 & 54.28 \\
\hline California & 60.00 & 66.00 & 45.00 & 9 & 7.66 & 4.00 & 6.37 & 2.17 & 64.00 & 1957 & 24.00 & 78837 & 54.28 \\
\hline California & 34.00 & 45.00 & 29.30 & 7 & - & 3.50 & - & - & 41.00 & 1965 & - & - & - \\
\hline California & 71.00 & 33.17 & 0.00 & 4 & 8.50 & 5.00 & 6.62 & 3.23 & 28.00 & 1953 & 30.00 & 205300 & 86.47 \\
\hline California & 59.00 & 73.00 & 29.00 & 6 & 13.08 & 2.75 & 8.50 & 0.00 & 64.00 & 1937 & 16.50 & 31860 & 63.70 \\
\hline California & 39.00 & 41.00 & 5.00 & 5 & 8.25 & 2.50 & 6.50 & 3.50 & 39.00 & 1965 & 15.00 & 14060 & 30.50 \\
\hline California & 38.00 & 40.50 & 0.00 & 5 & 9.00 & 3.50 & 7.00 & 2.21 & 39.00 & 1966 & 21.00 & 46450 & 45.50 \\
\hline California & 53.00 & 33.75 & 24.36 & 4 & 8.00 & 4.75 & 6.50 & 3.75 & 28.00 & 1971 & 28.50 & 150250 & 70.70 \\
\hline California & 72.00 & 33.75 & 24.36 & 4 & 8.00 & 4.75 & 6.50 & 3.75 & 28.00 & 1971 & 28.50 & 150250 & 70.70 \\
\hline California & 43.00 & 33.75 & 33.21 & 6 & 6.25 & 3.50 & 7.25 & 0.71 & 32.00 & 1932 & 21.00 & 52454 & 52.13 \\
\hline California & 43.00 & 23.75 & 33.21 & 4 & 6.25 & 3.50 & 7.25 & 1.75 & 22.00 & 1932 & 21.00 & 52454 & 52.13 \\
\hline California & 33.00 & 33.00 & 22.00 & 3 & 12.75 & 5.00 & 9.00 & 2.88 & 30.00 & 1935 & 27.00 & 159470 & 94.50 \\
\hline California & 31.50 & 31.50 & 30.00 & 6 & 5.83 & 2.25 & - & - & 28.00 & 1956 & - & - & - \\
\hline California & 30.66 & 30.66 & 0.00 & 4 & 8.00 & 2.33 & 8.00 & 2.38 & 26.00 & 1938 & 14.00 & 10000 & 30.00 \\
\hline California & 30.66 & 30.66 & 0.00 & 4 & 8.00 & 2.33 & 8.00 & 2.38 & 26.00 & 1938 & 14.00 & 10000 & 30.00 \\
\hline California & 39.66 & 39.66 & 12.37 & 7 & 6.00 & 3.33 & 6.00 & 1.83 & 37.66 & 1966 & 20.00 & 39304 & 40.80 \\
\hline California & 39.66 & 39.66 & 12.37 & 7 & 6.00 & 3.33 & 6.00 & 1.83 & 37.66 & 1966 & 20.00 & 39304 & 40.80 \\
\hline California & 42.17 & 42.17 & 24.87 & 7 & 6.83 & 4.75 & 6.37 & 0.00 & 40.00 & 1954 & 28.50 & 151416 & 70.80 \\
\hline California & 58.00 & 58.00 & 0.00 & 8 & 7.50 & 2.50 & 6.25 & 3.00 & 52.00 & 1961 & 15.00 & 15629 & 33.25 \\
\hline California & 68.66 & 68.66 & 0.00 & 10 & 7.00 & 4.63 & 6.25 & 2.83 & 64.00 & 1963 & 27.76 & 99550 & 49.25 \\
\hline
\end{tabular}


Table 3.2 cont'd

\begin{tabular}{|c|c|c|c|c|c|c|c|c|c|c|c|c|c|}
\hline State & $\begin{array}{c}\text { Length } \\
\mathrm{ft}\end{array}$ & $\begin{array}{c}\text { Width } \\
\text { (out-to-out) } \\
\mathrm{ft}\end{array}$ & Skew & $\begin{array}{l}\text { No. of } \\
\text { Girders }\end{array}$ & $\begin{array}{c}\text { Girder } \\
\text { Spacing } \\
\mathrm{ft}\end{array}$ & $\begin{array}{l}\text { Girder } \\
\text { Depth } \\
\mathrm{ft}\end{array}$ & $\begin{array}{c}\text { Slab } \\
\text { Thick. } \\
\text { in }\end{array}$ & $\begin{array}{c}\text { Overhang } \\
\mathrm{ft}\end{array}$ & $\begin{array}{c}\text { Roadway } \\
\text { Width } \\
\mathrm{ft}\end{array}$ & Date & Eccentricity & $\begin{array}{c}\text { Moment of } \\
\text { Inertia } \\
\mathrm{in}^{4}\end{array}$ & $\begin{array}{c}\text { Area } \\
\text { in }^{2}\end{array}$ \\
\hline California & 45.83 & 45.83 & 10.05 & 6 & 8.00 & 5.17 & 6.50 & 2.66 & 41.00 & 1962 & 31.75 & 156700 & 61.00 \\
\hline Florida & 25.00 & 33.42 & 0.00 & 5 & 7.17 & 2.00 & 7.00 & 2.00 & 26.00 & 1960 & - & - & - \\
\hline Maine & 22.00 & 24.25 & 0.00 & 4 & 7.50 & 1.83 & 7.50 & 0.00 & 22.00 & 1981 & 14.75 & 15972 & 39.60 \\
\hline Maine & 23.00 & 23.00 & 0.00 & 5 & 5.33 & 2.17 & 8.00 & 0.00 & 20.00 & 1925 & 16.50 & 18250 & 41.40 \\
\hline Maine & 25.17 & 25.17 & 0.00 & 5 & 5.85 & 2.42 & 8.25 & 0.25 & 22.00 & 1954 & 17.63 & 31165 & 51.30 \\
\hline Maine & 22.25 & 22.25 & 15.00 & 5 & 5.21 & 3.33 & 8.00 & 0.00 & 20.00 & 1926 & 24.00 & 85333 & 64.00 \\
\hline Maine & 46.82 & 37.50 & 32.77 & 7 & 5.61 & 5.42 & 6.50 & 0.17 & 34.00 & 1952 & 15.75 & 31250 & 60.00 \\
\hline Maine & 62.44 & 37.50 & 32.77 & 7 & 5.61 & 5.42 & 6.50 & 0.17 & 34.00 & 1952 & 15.75 & 31250 & 60.00 \\
\hline Minnesota & 60.00 & 34.50 & 45.00 & 6 & 6.50 & 3.08 & 5.75 & 0.00 & 30.00 & 1952 & 21.88 & 100600 & 83.60 \\
\hline Minnesota & 58.00 & 34.71 & 0.00 & 6 & 6.56 & 3.08 & 5.75 & 0.00 & 30.00 & 1947 & 21.88 & 100600 & 83.60 \\
\hline Minnesota & 65.00 & 50.17 & 0.00 & 8 & 6.27 & 2.50 & 6.00 & 2.88 & 46.83 & 1979 & 13.55 & 74443 & 69.36 \\
\hline Minnesota & 68.25 & 42.00 & 0.00 & 7 & 6.00 & 3.08 & 6.75 & 2.50 & 46.83 & 1983 & 16.92 & 567348 & 68.63 \\
\hline New York & 39.00 & 34.33 & 0.00 & 4 & 8.33 & 2.96 & 9.00 & 4.66 & 22.00 & 1934 & 22.25 & 82021 & 78.10 \\
\hline Ohio & 60.00 & 31.17 & 0.00 & 6 & 4.87 & 3.92 & 6.50 & 2.50 & 24.00 & 1979 & 26.75 & 177364 & 96.35 \\
\hline Ohio & 40.00 & 32.25 & 0.00 & 7 & 4.96 & 2.21 & 6.50 & 0.54 & 29.00 & 1977 & 16.50 & 25588 & 43.73 \\
\hline Oklahoma & 50.00 & 41.67 & 0.00 & 6 & 7.00 & 2.04 & 5.00 & 1.25 & 40.00 & 1984 & 14.35 & 62160 & 62.20 \\
\hline Oklahoma & 50.00 & 42.00 & 0.00 & 6 & 7.00 & 2.87 & 5.00 & 1.00 & 40.00 & 1979 & - & - & - \\
\hline Oklahoma & 31.25 & 33.00 & 0.00 & 6 & 5.87 & - & 7.50 & - & 28.00 & 1942 & 15.75 & 11000 & 33.00 \\
\hline Oklahoma & 40.00 & 33.00 & 0.00 & 6 & 5.87 & - & 7.50 & - & 28.00 & 1942 & 24.00 & 91341 & 66.83 \\
\hline Oregon & 70.00 & 41.42 & 43.78 & 5 & 9.00 & 4.25 & 7.50 & 1.92 & 40.00 & 1962 & 25.50 & 89170 & 56.55 \\
\hline Oregon & 56.00 & 41.42 & 43.78 & 5 & 9.00 & 4.25 & 7.50 & 1.92 & 40.00 & 1962 & 25.50 & 89170 & 56.55 \\
\hline Oregon & 27.00 & 41.42 & 43.78 & 5 & 9.00 & 4.25 & 7.50 & 1.92 & 40.00 & 1962 & 25.50 & 89170 & 56.55 \\
\hline Oregon & 48.50 & 34.83 & 41.90 & 4 & 9.00 & 4.75 & 7.00 & 3.29 & 30.00 & 1961 & 28.50 & 151000 & 72.50 \\
\hline Oregon & 62.00 & 34.83 & 41.90 & 4 & 9.00 & 4.75 & 7.00 & 3.29 & 30.00 & 1961 & 28.50 & 151000 & 72.50 \\
\hline Oregon & 78.00 & 34.83 & 41.90 & 4 & 9.00 & 4.75 & 7.00 & 3.29 & 30.00 & 1961 & 28.50 & 151000 & 72.50 \\
\hline Oregon & 56.00 & 34.83 & 41.90 & 4 & 9.00 & 4.75 & 7.00 & 3.29 & 30.00 & 1961 & 28.50 & 151000 & 72.50 \\
\hline
\end{tabular}


Table 3.2 cont'd

\begin{tabular}{|c|c|c|c|c|c|c|c|c|c|c|c|c|c|}
\hline State & $\begin{array}{c}\text { Length } \\
\mathrm{ft}\end{array}$ & $\begin{array}{c}\text { Width } \\
\text { (out-to-out) } \\
\mathrm{ft}\end{array}$ & Skew & $\begin{array}{l}\text { No. of } \\
\text { Girders }\end{array}$ & $\begin{array}{c}\text { Girder } \\
\text { Spacing } \\
\mathrm{ft}\end{array}$ & $\begin{array}{c}\text { Girder } \\
\text { Depth } \\
\mathrm{ft}\end{array}$ & $\begin{array}{c}\text { Slab } \\
\text { Thick. } \\
\text { in }\end{array}$ & $\begin{array}{c}\text { Overhang } \\
\mathrm{ft}\end{array}$ & $\begin{array}{c}\text { Roadway } \\
\text { Width } \\
\mathrm{ft}\end{array}$ & Date & Eccentricity & $\begin{array}{c}\text { Moment of } \\
\text { Inertia } \\
\mathrm{in}^{4}\end{array}$ & $\begin{array}{c}\text { Area } \\
\text { in }^{2}\end{array}$ \\
\hline Oregon & 56.00 & 38.50 & 0.00 & 4 & 9.33 & 4.00 & 7.00 & 5.25 & 30.00 & 1948 & 24.00 & 97600 & 69.70 \\
\hline Oregon & 70.00 & 38.50 & 0.00 & 4 & 9.33 & 4.00 & 7.00 & 5.25 & 30.00 & 1948 & 24.00 & 97600 & 69.70 \\
\hline Oregon & 50.00 & 38.50 & 0.00 & 4 & 9.33 & 4.00 & 7.00 & 5.25 & 30.00 & 1948 & 21.00 & 53600 & 52.50 \\
\hline Oregon & 37.00 & 38.50 & 0.00 & 4 & 9.33 & 4.00 & 7.00 & 5.25 & 30.00 & 1948 & 21.00 & 53600 & 52.50 \\
\hline Oregon & 49.00 & 28.00 & - & 4 & - & 3.80 & 6.50 & 1.75 & 26.00 & 1951 & 18.50 & 39000 & 50.30 \\
\hline Oregon & 65.00 & 28.00 & - & 4 & - & 3.80 & 6.50 & 1.75 & 26.00 & 1951 & 18.50 & 39000 & 50.30 \\
\hline Oregon & 35.00 & 28.75 & 0.00 & 4 & 7.33 & 1.92 & 7.00 & 3.50 & 26.00 & 1939 & 15.00 & 14190 & 32.20 \\
\hline Oregon & 50.00 & 28.75 & 0.00 & 4 & 7.33 & 1.92 & 7.00 & 3.50 & 26.00 & 1939 & 15.00 & 14190 & 32.20 \\
\hline Oregon & 47.00 & 45.50 & 50.68 & 4 & 7.75 & 2.52 & 7.75 & 3.37 & 42.00 & 1979 & 19.00 & 55360 & 72.60 \\
\hline Oregon & 63.00 & 45.50 & 50.61 & 4 & 7.75 & 2.52 & 7.75 & 3.37 & 42.00 & 1979 & 19.00 & 55360 & 72.60 \\
\hline Oregon & 54.00 & 45.50 & 52.98 & 4 & 7.75 & 2.52 & 7.75 & 3.37 & 42.00 & 1979 & 19.00 & 55360 & 72.60 \\
\hline Oregon & 35.00 & 35.17 & 0.00 & 9 & 4.75 & 2.50 & 6.00 & 0.00 & 30.00 & 1954 & 18.00 & 29250 & 39.00 \\
\hline Oregon & 24.00 & 59.00 & 0.00 & - & - & - & 6.50 & 2.00 & 58.00 & 1951 & - & - & - \\
\hline Washington & 26.00 & 10.25 & 0.00 & 8 & - & 1.17 & 6.50 & 1.33 & 9.50 & 1974 & - & - & - \\
\hline Washington & 20.00 & 10.25 & 0.00 & 8 & - & 1.17 & 6.50 & 1.33 & 9.50 & 1974 & - & - & - \\
\hline Washington & 41.44 & 33.17 & 0.00 & 4 & 10.00 & 2.50 & 10.00 & - & 24.00 & 1926 & - & - & - \\
\hline Washington & 72.00 & 28.50 & 45.00 & 2 & 16.00 & 3.75 & 8.63 & 6.33 & 24.00 & 1934 & 27.74 & 164000 & 94.00 \\
\hline Washington & 50.00 & 28.50 & 45.00 & 2 & 16.00 & 2.75 & 8.63 & 6.33 & 24.00 & 1934 & 21.66 & 65216 & 70.00 \\
\hline Washington & 93.00 & 28.50 & 45.00 & 2 & 16.00 & 3.75 & 8.63 & 6.33 & 24.00 & 1934 & 27.74 & 164000 & 94.00 \\
\hline Washington & 45.00 & 26.71 & 0.00 & 4 & 7.17 & 2.75 & 6.50 & 3.79 & 24.00 & 1939 & 17.25 & 30200 & 40.20 \\
\hline Washington & 22.50 & 39.38 & 0.00 & 5 & 8.54 & 2.75 & 6.50 & 2.50 & 36.00 & 1946 & 16.75 & 27000 & 44.55 \\
\hline Washington & 32.00 & 39.33 & 45.00 & 17 & 2.42 & 1.63 & 5.50 & 0.17 & 36.00 & 1950 & 9.75 & 2972 & 18.00 \\
\hline Washington & 24.00 & 39.33 & 45.00 & 17 & 2.42 & 1.63 & 5.50 & 0.17 & 36.00 & 1950 & 9.75 & 2972 & 18.00 \\
\hline Washington & 25.00 & 17.42 & 0.00 & 3 & 6.75 & 2.33 & 8.00 & 1.42 & 16.00 & 1930 & 16.00 & 13824 & 28.80 \\
\hline Washington & 12.00 & 37.75 & 0.00 & 5 & 7.50 & 2.54 & 6.50 & 1.75 & 34.00 & 1948 & 15.25 & 19000 & 39.60 \\
\hline Washington & 45.00 & 37.75 & 0.00 & 5 & 7.50 & 2.54 & 6.50 & 1.75 & 34.00 & 1948 & 15.25 & 19000 & 39.60 \\
\hline
\end{tabular}


Table 3.2 cont'd

\begin{tabular}{|c|c|c|c|c|c|c|c|c|c|c|c|c|c|}
\hline State & $\begin{array}{c}\text { Length } \\
\mathrm{ft} \\
\end{array}$ & $\begin{array}{c}\text { Width } \\
\text { (out-to-out) } \\
\mathrm{ft} \\
\end{array}$ & Skew & $\begin{array}{l}\text { No. of } \\
\text { Girders }\end{array}$ & $\begin{array}{c}\text { Girder } \\
\text { Spacing } \\
\mathrm{ft}\end{array}$ & $\begin{array}{c}\text { Girder } \\
\text { Depth } \\
\mathrm{ft} \\
\end{array}$ & $\begin{array}{c}\text { Slab } \\
\text { Thick. } \\
\text { in } \\
\end{array}$ & $\begin{array}{c}\text { Overhang } \\
\mathrm{ft}\end{array}$ & \begin{tabular}{|c} 
Roadway \\
Width \\
$\mathrm{ft}$ \\
\end{tabular} & Date & Eccentricity & $\begin{array}{c}\text { Moment of } \\
\text { Inertia } \\
\mathrm{in}^{4} \\
\end{array}$ & $\begin{array}{c}\text { Area } \\
\mathrm{in}^{2} \\
\end{array}$ \\
\hline Washington & 40.00 & 22.83 & 0.00 & 2 & 12.00 & 4.08 & 11.00 & 3.00 & 20.00 & 1926 & - & - & - \\
\hline Washington & 56.00 & 22.83 & 0.00 & 2 & 12.00 & 4.08 & 11.00 & 3.00 & 20.00 & 1926 & - & - & - \\
\hline \multicolumn{14}{|c|}{ Bridge Database from Appendix B of the NCHRP Report 12-26 for Prestressed I-girder Bridges } \\
\hline Arizona & 84.50 & 47.17 & 14.08 & 7 & 6.83 & 4.50 & 7.00 & 2.25 & 40.00 & 1970 & 32.70 & 260730 & 78.90 \\
\hline Arizona & 45.00 & 47.17 & 14.08 & 7 & 6.83 & 4.50 & 7.00 & 2.25 & 40.00 & 1970 & 32.70 & 260730 & 78.90 \\
\hline Arizona & 89.67 & 95.17 & 29.12 & 11 & 8.58 & 4.50 & 8.50 & 3.42 & 92.00 & 1983 & 33.52 & 260730 & 78.90 \\
\hline Arizona & 77.00 & 40.58 & 20.00 & 6 & 7.00 & 3.75 & 7.00 & 2.21 & 38.00 & 1972 & 28.23 & 125390 & 56.00 \\
\hline Arizona & 78.50 & 35.17 & 20.00 & 6 & 5.58 & 3.75 & 6.50 & 2.71 & 30.00 & 1962 & 27.98 & 125390 & 56.00 \\
\hline California & 79.17 & 34.00 & 8.00 & 5 & 7.10 & 5.25 & 6.00 & 2.75 & 28.00 & 1961 & 32.27 & 260730 & 78.90 \\
\hline California & 113.00 & 43.00 & 0.00 & 7 & 6.42 & 6.33 & 6.87 & 2.50 & 40.00 & 1984 & 37.84 & 318000 & 64.20 \\
\hline California & 96.00 & 58.00 & 0.00 & 8 & 7.50 & 5.66 & 6.25 & 2.75 & 52.00 & 1962 & 34.53 & 248000 & 60.00 \\
\hline California & 70.50 & 58.00 & 0.00 & 8 & 7.50 & 5.66 & 6.25 & 2.75 & 52.00 & 1962 & 34.53 & 248000 & 60.00 \\
\hline California & 84.00 & 68.66 & 0.00 & 10 & 7.00 & 4.63 & 6.25 & 2.83 & 66.00 & 1964 & 31.43 & 187800 & 55.80 \\
\hline California & 61.63 & 74.00 & 0.00 & 10 & 7.66 & 3.66 & 6.25 & 2.50 & 73.00 & 1968 & 22.03 & 63300 & 43.20 \\
\hline California & 27.00 & 74.00 & 0.00 & 10 & 7.66 & 3.66 & 6.25 & 2.50 & 73.00 & 1968 & 22.03 & 63300 & 43.20 \\
\hline California & 80.00 & 45.83 & 10.50 & 6 & 8.00 & 5.14 & 6.25 & 3.16 & 41.00 & 1964 & 31.43 & 187800 & 55.80 \\
\hline California & 101.00 & 45.75 & 7.00 & 7 & 6.90 & 5.25 & 7.00 & 2.50 & 38.00 & 1981 & 31.80 & 187800 & 55.80 \\
\hline California & 84.00 & 190.00 & 0.00 & 19 & 9.10 & 5.38 & 7.13 & 3.64 & 188.00 & 1972 & 35.00 & 187800 & 55.80 \\
\hline California & 72.50 & 37.00 & 5.28 & 5 & 7.75 & 4.66 & 6.25 & 3.00 & 28.00 & 1967 & 28.33 & 137300 & 51.60 \\
\hline California & 62.25 & 37.00 & 5.28 & 5 & 7.75 & 4.66 & 6.25 & 3.00 & 28.00 & 1967 & 28.33 & 137300 & 51.60 \\
\hline California & 52.00 & 53.00 & 47.70 & 6 & 8.83 & 5.25 & 6.50 & 4.42 & 51.00 & 1970 & 31.55 & 187800 & 55.80 \\
\hline California & 76.25 & 53.00 & 47.70 & 6 & 8.83 & 5.25 & 6.50 & 4.42 & 51.00 & 1970 & 31.55 & 187800 & 55.80 \\
\hline California & 84.24 & 53.00 & 47.70 & 6 & 8.83 & 5.25 & 6.50 & 4.42 & 51.00 & 1970 & 31.55 & 187800 & 55.80 \\
\hline California & 47.50 & 43.50 & 11.04 & 5 & 8.75 & 5.33 & 7.75 & 4.25 & 40.00 & 1981 & 32.18 & 187800 & 55.80 \\
\hline California & 74.80 & 43.50 & 11.04 & 5 & 8.75 & 5.33 & 7.75 & 4.25 & 40.00 & 1981 & 32.18 & 187800 & 55.80 \\
\hline California & 91.50 & 43.50 & 11.04 & 5 & 8.75 & 5.33 & 7.75 & 4.25 & 40.00 & 1981 & 32.18 & 187800 & 55.80 \\
\hline
\end{tabular}


Table 3.2 cont'd

\begin{tabular}{|c|c|c|c|c|c|c|c|c|c|c|c|c|c|}
\hline State & $\begin{array}{c}\text { Length } \\
\mathrm{ft}\end{array}$ & $\begin{array}{c}\text { Width } \\
\text { (out-to-out) } \\
\mathrm{ft}\end{array}$ & Skew & $\begin{array}{l}\text { No. of } \\
\text { Girders }\end{array}$ & $\begin{array}{c}\text { Girder } \\
\text { Spacing } \\
\mathrm{ft}\end{array}$ & $\begin{array}{l}\text { Girder } \\
\text { Depth } \\
\mathrm{ft}\end{array}$ & $\begin{array}{c}\text { Slab } \\
\text { Thick. } \\
\text { in }\end{array}$ & $\begin{array}{c}\text { Overhang } \\
\mathrm{ft}\end{array}$ & $\begin{array}{c}\text { Roadway } \\
\text { Width } \\
\mathrm{ft}\end{array}$ & Date & Eccentricity & $\begin{array}{c}\text { Moment of } \\
\text { Inertia } \\
\mathrm{in}^{4}\end{array}$ & $\begin{array}{c}\text { Area } \\
\text { in }^{2}\end{array}$ \\
\hline California & 58.43 & 41.00 & 40.00 & 5 & 8.25 & 5.17 & 6.25 & 4.00 & 39.00 & 1970 & 31.43 & 187800 & 55.80 \\
\hline California & 94.33 & 41.00 & 40.00 & 5 & 8.25 & 5.17 & 6.25 & 4.00 & 39.00 & 1970 & 31.43 & 187800 & 55.80 \\
\hline California & 94.33 & 57.00 & 47.20 & 7 & 8.00 & 5.17 & 6.25 & 4.00 & 55.00 & 1970 & 31.43 & 187800 & 55.80 \\
\hline California & 109.75 & 66.00 & 19.15 & 10 & 6.64 & 5.58 & 6.00 & 3.08 & 48.00 & 1969 & 34.40 & 248600 & 60.00 \\
\hline California & 79.00 & 66.00 & 19.15 & 8 & 8.47 & 5.58 & 6.38 & 3.08 & 48.00 & 1969 & 34.59 & 248600 & 60.00 \\
\hline California & 90.00 & 52.00 & 14.10 & 8 & 6.58 & 4.42 & 6.00 & 2.96 & 40.00 & 1971 & 27.73 & 125390 & 56.00 \\
\hline California & 67.50 & 46.00 & 0.00 & 7 & 6.83 & 4.66 & 6.00 & 2.50 & 32.00 & 1963 & 28.20 & 137300 & 51.60 \\
\hline California & 97.21 & 82.00 & 9.18 & 10 & 8.25 & 6.25 & 6.25 & 3.87 & 80.00 & 1971 & 37.53 & 318000 & 64.20 \\
\hline California & 67.75 & 68.66 & 12.88 & 12 & 6.00 & 3.63 & 6.00 & 1.33 & 66.00 & 1963 & 21.90 & 63300 & 43.20 \\
\hline Florida & 40.00 & 31.17 & 0.00 & 4 & 9.70 & 3.00 & 7.00 & 6.00 & 28.00 & 1957 & 23.67 & 50980 & 36.90 \\
\hline Florida & 60.00 & 31.17 & 0.00 & 6 & 5.83 & 3.00 & 7.00 & 6.00 & 28.00 & 1957 & 23.67 & 50980 & 36.90 \\
\hline Florida & 82.00 & 46.75 & 0.00 & 5 & 9.69 & 4.50 & 7.50 & 3.17 & 44.00 & 1976 & 33.02 & 260730 & 78.90 \\
\hline Florida & 32.50 & 31.00 & 0.00 & 4 & 6.75 & 3.75 & 7.00 & 1.25 & 26.00 & 1960 & 28.23 & 125390 & 56.00 \\
\hline Florida & 72.00 & 31.00 & 0.00 & 4 & 6.75 & 3.75 & 7.00 & 1.25 & 26.00 & 1960 & 28.23 & 125390 & 56.00 \\
\hline Florida & 37.50 & 43.00 & 10.11 & 6 & 7.83 & 3.75 & 7.00 & 1.25 & 38.00 & 1960 & 28.23 & 125390 & 56.00 \\
\hline Florida & 64.50 & 43.00 & 10.11 & 6 & 7.83 & 3.75 & 7.00 & 1.25 & 38.00 & 1960 & 28.23 & 125390 & 56.00 \\
\hline Florida & 75.58 & 43.00 & 2.57 & 6 & 7.42 & 3.75 & 7.00 & 1.17 & 38.00 & 1960 & 28.23 & 125390 & 56.00 \\
\hline Florida & 63.58 & 31.50 & 3.50 & 5 & 5.50 & 3.75 & 7.00 & 1.25 & 26.00 & 1960 & 28.23 & 125390 & 56.00 \\
\hline Florida & 38.92 & 31.00 & 3.50 & 4 & 6.75 & 3.75 & 7.00 & 1.25 & 26.00 & 1960 & 28.23 & 125390 & 56.00 \\
\hline Florida & 79.00 & 42.50 & 0.00 & 9 & 4.75 & 3.75 & 7.00 & 1.17 & 38.00 & 1960 & 28.23 & 125390 & 56.00 \\
\hline Florida & 79.00 & 31.50 & 0.00 & 6 & 5.42 & 3.75 & 7.00 & 1.17 & 26.00 & 1960 & 28.23 & 125390 & 56.00 \\
\hline Florida & 47.50 & 31.50 & 0.00 & 4 & 9.03 & 3.75 & 7.00 & 1.17 & 26.00 & 1960 & 28.23 & 125390 & 56.00 \\
\hline Florida & 65.25 & 84.75 & 0.00 & 10 & 8.77 & 3.75 & 7.50 & 2.21 & 79.25 & 1975 & 33.02 & 260730 & 78.90 \\
\hline Florida & 87.00 & 84.75 & 0.00 & 10 & 8.77 & 3.75 & 7.50 & 2.21 & 79.25 & 1975 & 33.02 & 260730 & 78.90 \\
\hline Florida & 46.00 & 70.75 & 39.26 & 9 & 8.12 & 3.00 & 7.00 & 2.00 & 68.00 & 1980 & 23.67 & 50980 & 36.90 \\
\hline Florida & 113.75 & 70.75 & 39.26 & 15 & 4.50 & 4.50 & 7.00 & 2.00 & 68.00 & 1980 & 32.77 & 260730 & 78.90 \\
\hline
\end{tabular}


Table 3.2 cont'd

\begin{tabular}{|c|c|c|c|c|c|c|c|c|c|c|c|c|c|}
\hline State & $\begin{array}{c}\text { Length } \\
\mathrm{ft}\end{array}$ & $\begin{array}{c}\text { Width } \\
\text { (out-to-out) } \\
\mathrm{ft}\end{array}$ & Skew & $\begin{array}{l}\text { No. of } \\
\text { Girders }\end{array}$ & $\begin{array}{c}\text { Girder } \\
\text { Spacing } \\
\mathrm{ft}\end{array}$ & $\begin{array}{l}\text { Girder } \\
\text { Depth } \\
\mathrm{ft}\end{array}$ & $\begin{array}{c}\text { Slab } \\
\text { Thick. } \\
\text { in }\end{array}$ & $\begin{array}{c}\text { Overhang } \\
\mathrm{ft}\end{array}$ & $\begin{array}{c}\text { Roadway } \\
\text { Width } \\
\mathrm{ft}\end{array}$ & Date & Eccentricity & $\begin{array}{c}\text { Moment of } \\
\text { Inertia } \\
\mathrm{in}^{4}\end{array}$ & $\begin{array}{l}\text { Area } \\
\text { in }^{2}\end{array}$ \\
\hline Florida & 113.67 & 82.75 & 39.26 & 15 & 6.33 & 4.50 & 7.00 & 2.00 & 80.00 & 1980 & 32.77 & 260730 & 78.90 \\
\hline Florida & 46.00 & 82.75 & 39.26 & 11 & 7.67 & 3.00 & 7.00 & 2.00 & 80.00 & 1980 & 23.67 & 50980 & 36.90 \\
\hline Florida & 74.00 & 26.00 & 18.13 & 4 & 7.33 & 3.75 & 7.00 & 1.33 & 24.00 & 1962 & 28.23 & 125390 & 56.00 \\
\hline Florida & 65.00 & 26.00 & 18.13 & 4 & 7.33 & 3.75 & 7.00 & 1.33 & 24.00 & 1962 & 28.23 & 125390 & 56.00 \\
\hline Florida & 41.75 & 54.25 & 0.00 & 6 & 9.80 & 3.00 & 7.00 & 2.12 & 52.00 & 1970 & 23.67 & 50980 & 36.90 \\
\hline Florida & 61.50 & 54.25 & 0.00 & 10 & 5.44 & 3.00 & 7.00 & 2.12 & 52.00 & 1970 & 28.23 & 125390 & 56.00 \\
\hline Florida & 45.50 & 54.25 & 0.00 & 7 & 8.17 & 3.00 & 7.00 & 2.12 & 46.00 & 1970 & 23.67 & 50980 & 36.90 \\
\hline Florida & 91.50 & 54.25 & 0.00 & 7 & 8.17 & 4.50 & 7.00 & 1.79 & 46.00 & 1970 & 32.77 & 260730 & 78.90 \\
\hline Florida & 40.00 & 54.25 & 0.00 & 6 & 9.80 & 3.00 & 7.00 & 1.79 & 46.00 & 1970 & 23.67 & 50980 & 36.90 \\
\hline Florida & 50.75 & 62.25 & 39.23 & 8 & 8.14 & 3.00 & 7.00 & 1.79 & 60.00 & 1969 & 23.67 & 50980 & 36.90 \\
\hline Florida & 95.00 & 62.25 & 39.23 & 8 & 8.14 & 4.50 & 7.00 & 1.79 & 60.00 & 1969 & 32.77 & 260730 & 78.90 \\
\hline Florida & 71.00 & 67.67 & 7.12 & 10 & 7.33 & 3.75 & 7.00 & 0.33 & 64.00 & 1964 & 24.73 & 125390 & 56.00 \\
\hline Florida & 70.08 & 32.00 & 7.20 & 5 & 7.00 & 3.75 & 7.00 & 1.33 & 30.00 & 1964 & 24.73 & 125390 & 56.00 \\
\hline Florida & 36.75 & 35.33 & 4.28 & 4 & 10.00 & 3.00 & 7.00 & 1.83 & 33.00 & 1971 & 23.67 & 50980 & 36.90 \\
\hline Florida & 99.50 & 35.33 & 4.28 & 6 & 6.00 & 4.50 & 7.00 & 1.83 & 33.00 & 1971 & 29.27 & 260730 & 78.90 \\
\hline Florida & 36.00 & 52.00 & 9.22 & 6 & 8.96 & 3.00 & 7.25 & 1.50 & 50.00 & 1962 & 23.67 & 50980 & 36.90 \\
\hline Florida & 40.50 & 42.00 & 8.77 & 5 & 9.50 & 3.00 & 7.25 & 1.50 & 40.00 & 1961 & 20.17 & 50980 & 36.90 \\
\hline Florida & 35.00 & 52.00 & 18.15 & 6 & 9.60 & 3.00 & 7.25 & 1.25 & 50.00 & 1962 & 20.17 & 50980 & 36.90 \\
\hline Florida & 66.50 & 52.00 & 18.15 & 7 & 8.00 & 4.50 & 0.00 & 1.25 & 50.00 & 1962 & 24.78 & 125390 & 56.00 \\
\hline Florida & 95.07 & 89.50 & 0.00 & 14 & 6.51 & 4.50 & 7.50 & 2.00 & 81.50 & 1973 & 29.27 & 260730 & 78.90 \\
\hline Florida & 101.68 & 89.50 & 0.00 & 14 & 6.51 & 4.50 & 7.50 & 2.00 & 81.50 & 1973 & 29.27 & 260730 & 78.90 \\
\hline Florida & 129.00 & 89.50 & 0.00 & 12 & 7.77 & 6.00 & 7.50 & 2.00 & 81.50 & 1973 & 35.62 & 733320 & 108.50 \\
\hline Florida & 47.00 & 46.75 & 0.00 & 6 & 8.20 & 3.00 & 7.00 & 2.37 & 44.00 & 1978 & 20.17 & 50980 & 36.90 \\
\hline Florida & 82.00 & 46.75 & 0.00 & 5 & 9.69 & 4.50 & 7.50 & 2.33 & 44.00 & 1978 & 29.27 & 260730 & 78.90 \\
\hline Florida & 64.00 & 47.62 & 0.00 & 6 & 9.25 & 3.75 & 7.50 & 2.00 & 40.00 & 1976 & 24.73 & 125390 & 56.00 \\
\hline Minnesota & 96.02 & 42.00 & 19.27 & 6 & 6.83 & 4.50 & 6.00 & 3.42 & 36.00 & 1977 & 32.27 & 260730 & 78.90 \\
\hline
\end{tabular}


Table 3.2 cont'd

\begin{tabular}{|c|c|c|c|c|c|c|c|c|c|c|c|c|c|}
\hline State & $\begin{array}{c}\text { Length } \\
\mathrm{ft} \\
\end{array}$ & $\begin{array}{c}\text { Width } \\
\text { (out-to-out) } \\
\mathrm{ft}\end{array}$ & Skew & \begin{tabular}{c|} 
No. of \\
Girders
\end{tabular} & $\begin{array}{c}\text { Girder } \\
\text { Spacing } \\
\mathrm{ft}\end{array}$ & $\begin{array}{c}\text { Girder } \\
\text { Depth } \\
\mathrm{ft} \\
\end{array}$ & $\begin{array}{c}\text { Slab } \\
\text { Thick. } \\
\text { in } \\
\end{array}$ & $\begin{array}{c}\text { Overhang } \\
\mathrm{ft}\end{array}$ & \begin{tabular}{|c|} 
Roadway \\
Width \\
$\mathrm{ft}$
\end{tabular} & Date & Eccentricity & $\begin{array}{c}\text { Moment of } \\
\text { Inertia } \\
\mathrm{in}^{4} \\
\end{array}$ & $\begin{array}{c}\text { Area } \\
\mathrm{in}^{2} \\
\end{array}$ \\
\hline Minnesota & 81.00 & 50.83 & 0.00 & 8 & 6.50 & 3.75 & 9.00 & 1.92 & $4 \quad 47.00$ & 1976 & 29.23 & 125390 & 56.00 \\
\hline Minnesota & 74.50 & 47.17 & 0.00 & 5 & 10.25 & 3.75 & 8.00 & 2.54 & 44.00 & 1972 & 28.73 & 125390 & 56.00 \\
\hline Minnesota & 97.00 & 50.75 & 0.00 & 6 & 8.75 & 5.25 & 8.00 & 3.00 & 46.92 & 1975 & - & - & - \\
\hline Minnesota & 96.00 & 50.75 & 30.00 & 7 & 7.33 & 4.50 & 8.00 & 2.42 & 46.50 & 1975 & 33.27 & 260730 & 78.90 \\
\hline New York & 63.00 & 33.33 & 9.00 & 8 & 3.67 & 3.00 & 5.25 & 1.00 & 28.00 & 1957 & 16.46 & 79145 & 54.03 \\
\hline Ohio & 47.00 & 66.00 & 0.00 & 9 & 7.50 & 3.00 & 7.50 & 2.42 & 52.00 & 1967 & 26.65 & 59077 & 47.10 \\
\hline Oklahoma & 50.00 & 49.42 & 0.00 & 5 & 10.50 & 3.75 & 8.50 & 3.21 & 46.75 & 1970 & 29.98 & 125390 & 56.00 \\
\hline Oregon & 22.81 & 64.33 & 0.00 & 18 & 3.21 & 1.75 & 5.00 & 0.00 & 55.83 & 1962 & 11.30 & 40134 & 51.10 \\
\hline Oregon & 30.75 & 64.33 & 0.00 & 18 & 3.21 & 1.75 & 5.00 & 0.00 & 55.83 & 1962 & 11.30 & 40134 & 51.10 \\
\hline Oregon & 18.75 & 30.75 & 0.00 & 7 & 4.21 & 1.46 & 5.25 & 0.00 & 26.00 & 1975 & 5.83 & 9599 & 41.90 \\
\hline Oregon & 60.00 & 34.00 & 35.42 & 4 & 9.33 & 3.75 & 6.25 & 3.00 & 30.00 & 1964 & 27.86 & 125390 & 56.00 \\
\hline Oregon & 58.00 & 34.00 & 35.42 & 4 & 9.33 & 3.75 & 6.25 & 3.00 & 30.00 & 1964 & 27.86 & 125390 & 56.00 \\
\hline Oregon & 92.00 & 29.50 & 0.00 & 4 & 8.00 & 4.50 & 7.50 & 2.50 & 26.00 & 1970 & 33.00 & 260730 & 78.90 \\
\hline Oregon & 47.55 & 76.39 & 35.07 & 10 & 8.00 & 3.00 & 7.00 & - & - & 1964 & 23.67 & 50980 & 36.90 \\
\hline Oregon & 42.24 & 76.39 & 34.52 & 10 & 8.00 & 3.00 & 7.00 & - & - & 1964 & 23.67 & 50980 & 36.90 \\
\hline Washington & 136.20 & 53.73 & 0.00 & 8 & 6.75 & 6.13 & 7.00 & 3.25 & 52.00 & 1978 & 39.09 & 455967 & 62.63 \\
\hline Washington & 56.00 & 35.00 & 15.65 & 6 & 5.92 & 4.00 & 6.25 & 3.92 & 30.00 & 1961 & - & - & - \\
\hline Washington & 48.00 & 35.00 & 15.65 & 6 & 5.92 & 4.00 & 6.25 & 3.92 & 30.00 & 1961 & - & - & - \\
\hline Washington & 60.00 & 69.00 & 28.63 & 13 & 5.35 & - & - & - & 66.00 & 1964 & - & - & - \\
\hline Washington & 70.00 & 69.00 & 28.63 & 13 & 5.35 & - & - & - & 66.00 & 1964 & - & - & - \\
\hline Washington & 113.00 & 52.00 & 45.00 & 8 & 6.83 & 4.83 & 6.50 & 1.71 & 50.50 & 1966 & 31.10 & 249044 & 54.65 \\
\hline Washington & 66.75 & 35.00 & 0.00 & 6 & 5.44 & 3.67 & - & - & 28.00 & 1967 & - & - & - \\
\hline Washington & 41.00 & 35.00 & 0.00 & 6 & 5.44 & 3.67 & - & - & 28.00 & 1967 & - & - & - \\
\hline Washington & 48.00 & 42.17 & 22.00 & 6 & 7.25 & 6.13 & 7.00 & 3.00 & 40.00 & 1971 & 39.09 & 455967 & 62.63 \\
\hline Washington & 118.00 & 42.17 & 22.00 & 6 & 7.25 & 6.13 & 7.00 & 3.00 & 40.00 & 1971 & 39.09 & 455967 & 62.63 \\
\hline Washington & 90.00 & 42.17 & 22.00 & 6 & 7.25 & 6.13 & 7.00 & 3.00 & 40.00 & 1971 & 39.09 & 455967 & 62.63 \\
\hline
\end{tabular}




\section{Table 3.2 cont'd}

\begin{tabular}{|c|c|c|c|c|c|c|c|c|c|c|c|c|}
\hline State & $\begin{array}{c}\text { Length } \\
\mathrm{ft}\end{array}$ & $\begin{array}{c}\text { Width } \\
\text { (out-to-out) } \\
\mathrm{ft}\end{array}$ & Skew & $\begin{array}{c}\text { Go. of } \\
\text { Girders }\end{array}$ & $\begin{array}{c}\text { Girder } \\
\text { Spacing } \\
\mathrm{ft}\end{array}$ & $\begin{array}{c}\text { Girder } \\
\text { Depth } \\
\mathrm{ft}\end{array}$ & $\begin{array}{c}\text { Slab } \\
\text { Thick. } \\
\mathrm{in}\end{array}$ & $\begin{array}{c}\text { Overhang } \\
\mathrm{ft}\end{array}$ & $\begin{array}{c}\text { Roadway } \\
\text { Width } \\
\mathrm{ft}\end{array}$ & $\begin{array}{c}\text { Eccentricity } \\
\text { Date }\end{array}$ & $\begin{array}{c}\text { Moment of } \\
\text { Inertia } \\
\mathrm{in}\end{array}$ & $\begin{array}{c}\text { Area } \\
\mathrm{in}^{4}\end{array}$ \\
\hline in
\end{tabular}


Table 3.3 Parameter ranges for NCHRP 12-26 bridge database

\begin{tabular}{|c|c|c|c|}
\hline Parameter & Minimum & Maximum & Average \\
\hline Girder Spacing (ft) & 2.2 & 16 & 7.6 \\
\hline Span Length (ft) & 12 & 205 & 67.4 \\
\hline I (in $\left.{ }^{4}\right)$ & 1138 & $2,970,000$ & 164,296 \\
\hline Slab Thickness (in) & 4.4 & 12.0 & 7.2 \\
\hline
\end{tabular}


Table 3.4. NCHRP 12-26 parametric study database

\begin{tabular}{|c|c|c|c|c|c|}
\hline Seq & Slab & Girder & Span & Girder & Distribution \\
No. & Thickness (in) & Stiffness (in $\left.{ }^{4}\right)$ & Length (ft) & Spacing (ft) & Factor \\
\hline \hline 1 & 4.40 & 10000 & 20 & 3.50 & 0.675 \\
2 & 4.40 & 10000 & 20 & 5.00 & 0.844 \\
3 & 4.40 & 10000 & 20 & 7.50 & 1.150 \\
4 & 4.40 & 10000 & 20 & 10.00 & 1.410 \\
5 & 4.40 & 10000 & 20 & 16.00 & 1.704 \\
6 & 4.40 & 10000 & 64 & 3.50 & 0.636 \\
7 & 4.40 & 10000 & 64 & 5.00 & 0.668 \\
8 & 4.40 & 10000 & 64 & 7.50 & 0.751 \\
9 & 4.40 & 10000 & 64 & 10.00 & 0.871 \\
10 & 4.40 & 10000 & 64 & 16.00 & 1.113 \\
11 & 4.40 & 10000 & 130 & 3.50 & 0.631 \\
12 & 4.40 & 10000 & 130 & 5.00 & 0.654 \\
13 & 4.40 & 10000 & 130 & 7.50 & 0.701 \\
14 & 4.40 & 10000 & 130 & 10.00 & 0.753 \\
15 & 4.40 & 10000 & 130 & 16.00 & 0.861 \\
16 & 4.40 & 10000 & 200 & 3.50 & 0.628 \\
17 & 4.40 & 10000 & 200 & 5.00 & 0.652 \\
18 & 4.40 & 10000 & 200 & 7.50 & 0.692 \\
19 & 4.40 & 10000 & 200 & 10.00 & 0.732 \\
20 & 4.40 & 10000 & 200 & 16.00 & 0.808 \\
21 & 4.40 & 50000 & 20 & 3.50 & 0.837 \\
22 & 4.40 & 50000 & 20 & 5.00 & 1.106 \\
23 & 4.40 & 50000 & 20 & 7.50 & 1.588 \\
24 & 4.40 & 50000 & 20 & 10.00 & 1.919 \\
25 & 4.40 & 50000 & 20 & 16.00 & 2.605 \\
26 & 4.40 & 50000 & 64 & 3.50 & 0.690 \\
27 & 4.40 & 50000 & 64 & 5.00 & 0.851 \\
28 & 4.40 & 50000 & 64 & 7.50 & 1.134 \\
29 & 4.40 & 50000 & 64 & 10.00 & 1.399 \\
30 & 4.40 & 50000 & 64 & 16.00 & 1.885 \\
31 & 4.40 & 50000 & 130 & 3.50 & 0.674 \\
32 & 4.40 & 50000 & 130 & 5.00 & 0.740 \\
33 & 4.40 & 50000 & 130 & 7.50 & 0.889 \\
34 & 4.40 & 50000 & 130 & 10.00 & 1.070 \\
35 & 4.40 & 50000 & 130 & 16.00 & 1.338 \\
36 & 4.40 & 50000 & 200 & 3.50 & 0.672 \\
37 & 4.40 & 50000 & 200 & 5.00 & 0.714 \\
38 & 4.40 & 50000 & 200 & 7.50 & 0.806 \\
39 & 4.40 & 50000 & 200 & 10.00 & 0.926 \\
43 & 4.40 & 50000 & 200 & 16.00 & 1.131 \\
& 4.40 & 560000 & 20 & 3.50 & 0.960 \\
& 4.40 & 560000 & 20 & 5.00 & 1.183 \\
& 4.40 & 560000 & 20 & 7.50 & 1.655 \\
\hline
\end{tabular}


Table 3.4 cont'd

\begin{tabular}{|c|c|c|c|c|c|}
\hline $\begin{array}{l}\text { Seq } \\
\text { No. }\end{array}$ & $\begin{array}{c}\text { Slab } \\
\text { Thickness (in) } \\
\end{array}$ & $\begin{array}{c}\text { Girder } \\
\text { Stiffness }\left(\text { in }^{4}\right) \\
\end{array}$ & $\begin{array}{c}\text { Span } \\
\text { Length }(\mathrm{ft}) \\
\end{array}$ & $\begin{array}{c}\text { Girder } \\
\text { Spacing (ft) } \\
\end{array}$ & \begin{tabular}{|c|}
$\begin{array}{c}\text { Distribution } \\
\text { Factor }\end{array}$ \\
\end{tabular} \\
\hline 444 & 4.40 & 560000 & 20 & 10.00 & 1.989 \\
\hline 45 & 4.40 & 560000 & 20 & 16.00 & 2.731 \\
\hline 46 & 4.40 & 560000 & 64 & 3.50 & 0.714 \\
\hline 47 & 4.40 & 560000 & 64 & 5.00 & 0.991 \\
\hline 48 & 4.40 & 560000 & 64 & 7.50 & 1.445 \\
\hline 49 & 4.40 & 560000 & 64 & 10.00 & 1.812 \\
\hline 50 & 4.40 & 560000 & 64 & 16.00 & 2.543 \\
\hline 51 & 4.40 & 560000 & 130 & 3.50 & 0.698 \\
\hline 52 & 4.40 & 560000 & 130 & 5.00 & 0.884 \\
\hline 53 & 4.40 & 560000 & 130 & 7.50 & 1.170 \\
\hline 54 & 4.40 & 560000 & 130 & 10.00 & 1.425 \\
\hline 55 & 4.40 & 560000 & 130 & 16.00 & 1.926 \\
\hline 56 & 4.40 & 560000 & 200 & 3.50 & 0.686 \\
\hline 57 & 4.40 & 560000 & 200 & 5.00 & 0.813 \\
\hline 58 & 4.40 & 560000 & 200 & 7.50 & 1.039 \\
\hline 59 & 4.40 & 560000 & 200 & 10.00 & 1.253 \\
\hline 60 & 4.40 & 560000 & 200 & 16.00 & 1.566 \\
\hline 61 & 4.40 & 3000000 & 20 & 3.50 & 0.991 \\
\hline 62 & 4.40 & 3000000 & 20 & 5.00 & 1.197 \\
\hline 63 & 4.40 & 3000000 & 20 & 7.50 & 1.665 \\
\hline 64 & 4.40 & 3000000 & 20 & 10.00 & 1.998 \\
\hline 65 & 4.40 & 3000000 & 20 & 16.00 & 2.745 \\
\hline 66 & 4.40 & 3000000 & 64 & 3.50 & 0.808 \\
\hline 67 & 4.40 & 3000000 & 64 & 5.00 & 1.101 \\
\hline 68 & 4.40 & 3000000 & 64 & 7.50 & 1.601 \\
\hline 69 & 4.40 & 3000000 & 64 & 10.00 & 1.955 \\
\hline 70 & 4.40 & 3000000 & 64 & 16.00 & 2.704 \\
\hline 71 & 4.40 & 3000000 & 130 & 3.50 & 0.717 \\
\hline 72 & 4.40 & 3000000 & 130 & 5.00 & 0.971 \\
\hline 73 & 4.40 & 3000000 & 130 & 7.50 & 1.376 \\
\hline 74 & 4.40 & 3000000 & 130 & 10.00 & 1.724 \\
\hline 75 & 4.40 & 3000000 & 130 & 16.00 & 2.424 \\
\hline 76 & 4.40 & 3000000 & 200 & 3.50 & 0.712 \\
\hline 77 & 4.40 & 3000000 & 200 & 5.00 & 0.929 \\
\hline 78 & 4.40 & 3000000 & 200 & 7.50 & 1.219 \\
\hline 79 & 4.40 & 3000000 & 200 & 10.00 & 1.470 \\
\hline 80 & 4.40 & 3000000 & 200 & 16.00 & 2.006 \\
\hline 81 & 4.40 & 7000000 & 20 & 3.50 & 0.996 \\
\hline 82 & 4.40 & 7000000 & 20 & 5.00 & 1.198 \\
\hline 83 & 4.40 & 7000000 & 20 & 7.50 & 1.666 \\
\hline 84 & 4.40 & 7000000 & 20 & 10.00 & 1.999 \\
\hline 85 & 4.40 & 7000000 & 20 & 16.00 & 2.748 \\
\hline 86 & 4.40 & 7000000 & 64 & 3.50 & 0.866 \\
\hline
\end{tabular}


Table 3.4 cont'd

\begin{tabular}{|c|c|c|c|c|c|}
\hline $\begin{array}{l}\text { Seq } \\
\text { No. }\end{array}$ & \begin{tabular}{|c|}
\multicolumn{2}{c|}{ Slab } \\
Thickness (in)
\end{tabular} & \begin{tabular}{|c|} 
Girder \\
Stiffness $\left(\mathrm{in}^{4}\right)$
\end{tabular} & $\begin{array}{c}\text { Span } \\
\text { Length }(\mathrm{ft})\end{array}$ & $\begin{array}{c}\text { Girder } \\
\text { Spacing (ft) }\end{array}$ & $\begin{array}{c}\begin{array}{c}\text { Distribution } \\
\text { Factor }\end{array} \\
\end{array}$ \\
\hline 87 & 4.40 & 7000000 & 64 & 5.00 & 1.138 \\
\hline 88 & 4.40 & 7000000 & 64 & 7.50 & 1.634 \\
\hline 89 & 4.40 & 7000000 & 64 & 10.00 & 1.979 \\
\hline 90 & 4.40 & 7000000 & 64 & 16.00 & 2.728 \\
\hline 91 & 4.40 & 7000000 & 130 & 3.50 & 0.731 \\
\hline 92 & 4.40 & 7000000 & 130 & 5.00 & 1.036 \\
\hline 93 & 4.40 & 7000000 & 130 & 7.50 & 1.477 \\
\hline 94 & 4.40 & 7000000 & 130 & 10.00 & 1.847 \\
\hline 95 & 4.40 & 7000000 & 130 & 16.00 & 2.597 \\
\hline 96 & 4.40 & 7000000 & 200 & 3.50 & 0.719 \\
\hline 97 & 4.40 & 7000000 & 200 & 5.00 & 0.962 \\
\hline 98 & 4.40 & 7000000 & 200 & 7.50 & 1.305 \\
\hline 99 & 4.40 & 7000000 & 200 & 10.00 & 1.614 \\
\hline 100 & 4.40 & 7000000 & 200 & 16.00 & 2.259 \\
\hline 101 & 7.25 & 10000 & 20 & 3.50 & 0.621 \\
\hline 102 & 7.25 & 10000 & 20 & 5.00 & 0.784 \\
\hline 103 & 7.25 & 10000 & 20 & 7.50 & 1.078 \\
\hline 104 & 7.25 & 10000 & 20 & 10.00 & 1.318 \\
\hline 105 & 7.25 & 10000 & 20 & 16.00 & 1.584 \\
\hline 106 & 7.25 & 10000 & 64 & 3.50 & 0.585 \\
\hline 107 & 7.25 & 10000 & 64 & 5.00 & 0.644 \\
\hline 108 & 7.25 & 10000 & 64 & 7.50 & 0.749 \\
\hline 109 & 7.25 & 10000 & 64 & 10.00 & 0.876 \\
\hline 110 & 7.25 & 10000 & 64 & 16.00 & 1.119 \\
\hline 111 & 7.25 & 10000 & 130 & 3.50 & 0.579 \\
\hline 112 & 7.25 & 10000 & 130 & 5.00 & 0.527 \\
\hline 113 & 7.25 & 10000 & 130 & 7.50 & 0.695 \\
\hline 114 & 7.25 & 10000 & 130 & 10.00 & 0.762 \\
\hline 115 & 7.25 & 10000 & 130 & 16.00 & 0.890 \\
\hline 116 & 7.25 & 10000 & 200 & 3.50 & 0.578 \\
\hline 117 & 7.25 & 10000 & 200 & 5.00 & 0.624 \\
\hline 118 & 7.25 & 10000 & 200 & 7.50 & 0.685 \\
\hline 119 & 7.25 & 10000 & 200 & 10.00 & 0.738 \\
\hline 120 & 7.25 & 10000 & 200 & 16.00 & 0.829 \\
\hline 121 & 7.25 & 50000 & 20 & 3.50 & 0.761 \\
\hline 122 & 7.25 & 50000 & 20 & 5.00 & 1.017 \\
\hline 123 & 7.25 & 50000 & 20 & 7.50 & 1.453 \\
\hline 124 & 7.25 & 50000 & 20 & 10.00 & 1.762 \\
\hline 125 & 7.25 & 50000 & 20 & 16.00 & 2.320 \\
\hline 126 & 7.25 & 50000 & 64 & 3.50 & 0.681 \\
\hline 127 & 7.25 & 50000 & 64 & 5.00 & 0.808 \\
\hline 128 & 7.25 & 50000 & 64 & 7.50 & 1.027 \\
\hline 129 & 7.25 & 50000 & 64 & 10.00 & 1.232 \\
\hline
\end{tabular}


Table 3.4 cont'd

\begin{tabular}{|c|c|c|c|c|c|}
\hline Seq & Slab & Girder & Span & Girder & Distribution \\
No. & Thickness (in) & Stiffness (in $\left.{ }^{4}\right)$ & Length (ft) & Spacing (ft) & Factor \\
\hline \hline 130 & 7.25 & 50000 & 64 & 16.00 & 1.535 \\
131 & 7.25 & 50000 & 130 & 3.50 & 0.669 \\
132 & 7.25 & 50000 & 130 & 5.00 & 0.726 \\
133 & 7.25 & 50000 & 130 & 7.50 & 0.840 \\
134 & 7.25 & 50000 & 130 & 10.00 & 0.972 \\
135 & 7.25 & 50000 & 130 & 16.00 & 1.169 \\
136 & 7.25 & 50000 & 200 & 3.50 & 0.667 \\
137 & 7.25 & 50000 & 200 & 5.00 & 0.706 \\
138 & 7.25 & 50000 & 200 & 7.50 & 0.781 \\
139 & 7.25 & 50000 & 200 & 10.00 & 0.870 \\
140 & 7.25 & 50000 & 200 & 16.00 & 1.014 \\
141 & 7.25 & 560000 & 20 & 3.50 & 0.898 \\
142 & 7.25 & 560000 & 20 & 5.00 & 1.150 \\
143 & 7.25 & 560000 & 20 & 7.50 & 1.630 \\
144 & 7.25 & 560000 & 20 & 10.00 & 1.962 \\
145 & 7.25 & 560000 & 20 & 16.00 & 2.681 \\
146 & 7.25 & 560000 & 64 & 3.50 & 0.713 \\
147 & 7.25 & 560000 & 64 & 5.00 & 0.948 \\
148 & 7.25 & 560000 & 64 & 7.50 & 1.293 \\
149 & 7.25 & 560000 & 64 & 10.00 & 1.599 \\
150 & 7.25 & 560000 & 64 & 16.00 & 2.220 \\
151 & 7.25 & 560000 & 130 & 3.50 & 0.697 \\
152 & 7.25 & 560000 & 130 & 5.00 & 0.858 \\
153 & 7.25 & 560000 & 130 & 7.50 & 1.087 \\
154 & 7.25 & 560000 & 130 & 10.00 & 1.232 \\
155 & 7.25 & 560000 & 130 & 16.00 & 1.580 \\
156 & 7.25 & 560000 & 200 & 3.50 & 0.685 \\
157 & 7.25 & 560000 & 200 & 5.00 & 0.796 \\
158 & 7.25 & 560000 & 200 & 7.50 & 0.982 \\
159 & 7.25 & 560000 & 200 & 10.00 & 1.157 \\
160 & 7.25 & 560000 & 200 & 16.00 & 1.367 \\
161 & 7.25 & 3000000 & 20 & 3.50 & 0.970 \\
162 & 7.25 & 3000000 & 20 & 5.00 & 1.188 \\
163 & 7.25 & 3000000 & 20 & 7.50 & 1.659 \\
164 & 7.25 & 3000000 & 20 & 10.00 & 1.992 \\
165 & 7.25 & 3000000 & 20 & 16.00 & 2.736 \\
166 & 7.25 & 3000000 & 64 & 3.50 & 0.734 \\
167 & 7.25 & 3000000 & 64 & 5.00 & 1.047 \\
168 & 7.25 & 3000000 & 64 & 7.50 & 1.503 \\
169 & 7.25 & 3000000 & 64 & 10.00 & 1.863 \\
170 & 7.25 & 3000000 & 64 & 16.00 & 2.595 \\
& 7.25 & 3000000 & 130 & 3.50 & 0.721 \\
& 7.25 & 3000000 & 130 & 5.00 & 0.952 \\
\hline
\end{tabular}


Table 3.4 cont'd

\begin{tabular}{|c|c|c|c|c|c|}
\hline Seq & Slab & Girder & Span & Girder & Distribution \\
No. & Thickness (in) & Stiffness (in $\left.{ }^{4}\right)$ & Length (ft) & Spacing (ft) & Factor \\
\hline \hline 173 & 7.25 & 3000000 & 130 & 7.50 & 1.238 \\
174 & 7.25 & 3000000 & 130 & 10.00 & 1.489 \\
175 & 7.25 & 3000000 & 130 & 16.00 & 2.046 \\
176 & 7.25 & 3000000 & 200 & 3.50 & 0.712 \\
177 & 7.25 & 3000000 & 200 & 5.00 & 0.909 \\
178 & 7.25 & 3000000 & 200 & 7.50 & 1.147 \\
179 & 7.25 & 3000000 & 200 & 10.00 & 1.336 \\
180 & 7.25 & 3000000 & 200 & 16.00 & 1.643 \\
181 & 7.25 & 7000000 & 20 & 3.50 & 0.985 \\
182 & 7.25 & 7000000 & 20 & 5.00 & 1.194 \\
183 & 7.25 & 7000000 & 20 & 7.50 & 1.663 \\
184 & 7.25 & 7000000 & 20 & 10.00 & 1.996 \\
185 & 7.25 & 7000000 & 20 & 16.00 & 2.743 \\
186 & 7.25 & 7000000 & 64 & 3.50 & 0.775 \\
187 & 7.25 & 7000000 & 64 & 5.00 & 1.085 \\
188 & 7.25 & 7000000 & 64 & 7.50 & 1.574 \\
189 & 7.25 & 7000000 & 64 & 10.00 & 1.935 \\
190 & 7.25 & 7000000 & 64 & 16.00 & 2.675 \\
191 & 7.25 & 7000000 & 130 & 3.50 & 0.723 \\
192 & 7.25 & 7000000 & 130 & 5.00 & 0.974 \\
193 & 7.25 & 7000000 & 130 & 7.50 & 1.323 \\
194 & 7.25 & 7000000 & 130 & 10.00 & 1.644 \\
195 & 7.25 & 7000000 & 130 & 16.00 & 2.297 \\
196 & 7.25 & 7000000 & 200 & 3.50 & 0.722 \\
197 & 7.25 & 7000000 & 200 & 5.00 & 0.944 \\
198 & 7.25 & 7000000 & 200 & 7.50 & 1.202 \\
199 & 7.25 & 7000000 & 200 & 10.00 & 1.414 \\
200 & 7.25 & 7000000 & 200 & 16.00 & 1.853 \\
201 & 12.00 & 10000 & 20 & 3.50 & 0.591 \\
202 & 12.00 & 10000 & 20 & 5.00 & 0.774 \\
203 & 12.00 & 10000 & 20 & 7.50 & 1.073 \\
204 & 12.00 & 10000 & 20 & 10.00 & 1.310 \\
205 & 12.00 & 10000 & 20 & 16.00 & 1.571 \\
206 & 12.00 & 10000 & 64 & 3.50 & 0.549 \\
207 & 12.00 & 10000 & 64 & 5.00 & 0.622 \\
208 & 12.00 & 10000 & 64 & 7.50 & 0.781 \\
209 & 12.00 & 10000 & 64 & 10.00 & 0.903 \\
210 & 12.00 & 10000 & 64 & 16.00 & 1.151 \\
211 & 12.00 & 10000 & 130 & 3.50 & 0.544 \\
212 & 12.00 & 10000 & 130 & 5.00 & 0.612 \\
213 & 12.00 & 10000 & 130 & 7.50 & 0.697 \\
214 & 12.00 & 10000 & 130 & 10.00 & 0.778 \\
215 & 12.00 & 10000 & 130 & 16.00 & 0.922 \\
\hline & & & & & \\
\hline
\end{tabular}


Table 3.4 cont'd

\begin{tabular}{|c|c|c|c|c|c|}
\hline Seq & Slab & Girder & Span & Girder & Distribution \\
No. & Thickness (in) & Stiffness (in $\left.{ }^{4}\right)$ & Length (ft) & Spacing (ft) & Factor \\
\hline \hline 216 & 12.00 & 10000 & 200 & 3.50 & 0.543 \\
217 & 12.00 & 10000 & 200 & 5.00 & 0.610 \\
218 & 12.00 & 10000 & 200 & 7.50 & 0.686 \\
219 & 12.00 & 10000 & 200 & 10.00 & 0.747 \\
220 & 12.00 & 10000 & 200 & 16.00 & 0.850 \\
221 & 12.00 & 50000 & 20 & 3.50 & 0.711 \\
222 & 12.00 & 50000 & 20 & 5.00 & 0.927 \\
223 & 12.00 & 50000 & 20 & 7.50 & 1.288 \\
224 & 12.00 & 50000 & 20 & 10.00 & 1.543 \\
225 & 12.00 & 50000 & 20 & 16.00 & 1.901 \\
226 & 12.00 & 50000 & 64 & 3.50 & 0.659 \\
227 & 12.00 & 50000 & 64 & 5.00 & 0.755 \\
228 & 12.00 & 50000 & 64 & 7.50 & 0.922 \\
229 & 12.00 & 50000 & 64 & 10.00 & 1.092 \\
230 & 12.00 & 50000 & 64 & 16.00 & 1.326 \\
231 & 12.00 & 50000 & 130 & 3.50 & 0.651 \\
232 & 12.00 & 50000 & 130 & 5.00 & 0.699 \\
233 & 12.00 & 50000 & 130 & 7.50 & 0.783 \\
234 & 12.00 & 50000 & 130 & 10.00 & 0.879 \\
235 & 12.00 & 50000 & 130 & 16.00 & 1.033 \\
236 & 12.00 & 50000 & 200 & 3.50 & 0.651 \\
237 & 12.00 & 50000 & 200 & 5.00 & 0.688 \\
238 & 12.00 & 50000 & 200 & 7.50 & 0.745 \\
239 & 12.00 & 50000 & 200 & 10.00 & 0.809 \\
240 & 12.00 & 50000 & 200 & 16.00 & 0.917 \\
241 & 12.00 & 560000 & 20 & 3.50 & 0.814 \\
242 & 12.00 & 560000 & 20 & 5.00 & 1.090 \\
243 & 12.00 & 560000 & 20 & 7.50 & 1.553 \\
244 & 12.00 & 560000 & 20 & 10.00 & 1.874 \\
245 & 12.00 & 560000 & 20 & 16.00 & 2.515 \\
246 & 12.00 & 560000 & 64 & 3.50 & 0.708 \\
247 & 12.00 & 560000 & 64 & 5.00 & 0.908 \\
248 & 12.00 & 560000 & 64 & 7.50 & 1.163 \\
249 & 12.00 & 560000 & 64 & 10.00 & 1.376 \\
250 & 12.00 & 560000 & 64 & 16.00 & 1.774 \\
251 & 12.00 & 560000 & 130 & 3.50 & 0.688 \\
252 & 12.00 & 560000 & 130 & 5.00 & 0.811 \\
253 & 12.00 & 560000 & 130 & 7.50 & 0.990 \\
254 & 12.00 & 560000 & 130 & 10.00 & 1.150 \\
255 & 12.00 & 560000 & 130 & 16.00 & 1.346 \\
& 12.00 & 560000 & 200 & 3.50 & 0.680 \\
& 12.00 & 560000 & 200 & 5.00 & 0.762 \\
\hline & 12.00 & 560000 & 200 & 7.50 & 0.894 \\
\hline
\end{tabular}


Table 3.4 cont'd

\begin{tabular}{|c|c|c|c|c|c|}
\hline Seq & Slab & Girder & Span & Girder & Distribution \\
No. & Thickness (in) & Stiffness (in $\left.{ }^{4}\right)$ & Length (ft) & Spacing (ft) & Factor \\
\hline \hline 259 & 12.00 & 560000 & 200 & 10.00 & 1.028 \\
260 & 12.00 & 560000 & 200 & 16.00 & 1.191 \\
261 & 12.00 & 3000000 & 20 & 3.50 & 0.918 \\
262 & 12.00 & 3000000 & 20 & 5.00 & 1.161 \\
263 & 12.00 & 3000000 & 20 & 7.50 & 1.640 \\
264 & 12.00 & 3000000 & 20 & 10.00 & 1.971 \\
265 & 12.00 & 3000000 & 20 & 16.00 & 2.696 \\
266 & 12.00 & 3000000 & 64 & 3.50 & 0.721 \\
267 & 12.00 & 3000000 & 64 & 5.00 & 0.972 \\
268 & 12.00 & 3000000 & 64 & 7.50 & 1.340 \\
269 & 12.00 & 3000000 & 64 & 10.00 & 1.664 \\
270 & 12.00 & 3000000 & 64 & 16.00 & 2.303 \\
271 & 12.00 & 3000000 & 130 & 3.50 & 0.718 \\
272 & 12.00 & 3000000 & 130 & 5.00 & 0.919 \\
273 & 12.00 & 3000000 & 130 & 7.50 & 1.148 \\
274 & 12.00 & 3000000 & 130 & 10.00 & 1.328 \\
275 & 12.00 & 3000000 & 130 & 16.00 & 1.637 \\
276 & 12.00 & 3000000 & 200 & 3.50 & 0.703 \\
277 & 12.00 & 3000000 & 200 & 5.00 & 0.867 \\
278 & 12.00 & 3000000 & 200 & 7.50 & 1.070 \\
279 & 12.00 & 3000000 & 200 & 10.00 & 1.232 \\
280 & 12.00 & 3000000 & 200 & 16.00 & 1.420 \\
281 & 12.00 & 7000000 & 20 & 3.50 & 0.953 \\
282 & 12.00 & 7000000 & 20 & 5.00 & 1.180 \\
283 & 12.00 & 7000000 & 20 & 7.50 & 1.654 \\
284 & 12.00 & 7000000 & 20 & 10.00 & 1.986 \\
285 & 12.00 & 7000000 & 20 & 16.00 & 2.725 \\
286 & 12.00 & 7000000 & 64 & 3.50 & 0.714 \\
287 & 12.00 & 7000000 & 64 & 5.00 & 1.023 \\
288 & 12.00 & 7000000 & 64 & 7.50 & 1.448 \\
289 & 12.00 & 7000000 & 64 & 10.00 & 1.803 \\
290 & 12.00 & 7000000 & 64 & 16.00 & 2.501 \\
291 & 12.00 & 7000000 & 130 & 3.50 & 0.726 \\
292 & 12.00 & 7000000 & 130 & 5.00 & 0.951 \\
293 & 12.00 & 7000000 & 130 & 7.50 & 1.203 \\
294 & 12.00 & 7000000 & 130 & 10.00 & 1.413 \\
295 & 12.00 & 7000000 & 130 & 16.00 & 1.863 \\
296 & 12.00 & 7000000 & 200 & 3.50 & 0.716 \\
297 & 12.00 & 7000000 & 200 & 5.00 & 0.913 \\
298 & 12.00 & 7000000 & 200 & 7.50 & 1.133 \\
300 & 12.00 & 7000000 & 200 & 10.00 & 1.301 \\
& 12.00 & 7000000 & 200 & 16.00 & 1.537 \\
\hline
\end{tabular}


Table 3.5. Representative AASHTO LRFD distribution factors (partial reprint from AASHTO Table 4.6.2.2.2b-1) (AASHTO, 2002)

\begin{tabular}{|c|c|c|c|}
\hline Types of Beams & $\begin{array}{c}\text { Applicable } \\
\text { Cross-Section } \\
\text { from Table } \\
4.6 .2 .2 .1-1\end{array}$ & Distribution Factors & $\begin{array}{l}\text { Range of } \\
\text { Applicability }\end{array}$ \\
\hline \multirow[t]{2}{*}{$\begin{array}{l}\text { Concrete Deck, Filled } \\
\text { Grid, or Partially Filled } \\
\text { Grid on Steel or Concrete } \\
\text { Beams, T- and Double T- } \\
\text { Sections }\end{array}$} & \multirow[t]{2}{*}{$\begin{array}{c}a, e, k \text { and also } \\
I, j \\
\text { if sufficiently } \\
\text { connected to } \\
\text { act as a unit }\end{array}$} & $\begin{array}{l}\text { One Design Lane Loaded: } \\
0.06+\left(\frac{S}{14}\right)^{0.4}\left(\frac{S}{L}\right)^{0.3}\left(\frac{K_{g}}{12.0 L t_{s}^{3}}\right)^{0.1} \\
\text { Two or More Design Lanes Loaded: } \\
0.075+\left(\frac{S}{9.5}\right)^{0.6}\left(\frac{S}{L}\right)^{0.2}\left(\frac{K_{g}}{12.0 L t_{s}^{3}}\right)^{0.1}\end{array}$ & $\begin{array}{l}3.5 \leq S \leq 16.0 \\
4.5 \leq t_{s} \leq 12.0 \\
20 \leq L \leq 240 \\
N_{b} \geq 4\end{array}$ \\
\hline & & $\begin{array}{l}\text { use lesser of the values obtained from } \\
\text { the equation above with } N_{b}=3 \text { or the } \\
\text { lever rule }\end{array}$ & $N_{b}=3$ \\
\hline
\end{tabular}




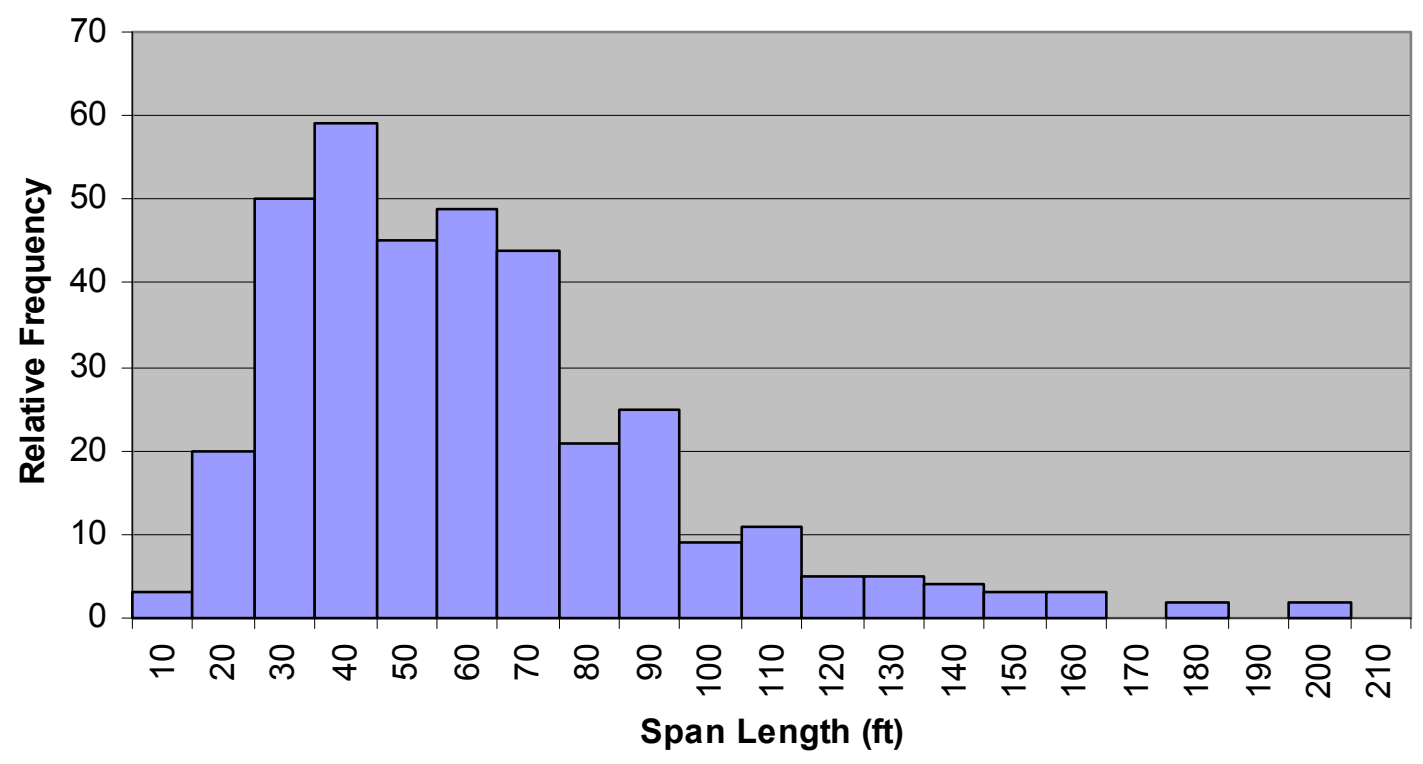

Figure 3.1. Histogram of relative frequency for span length

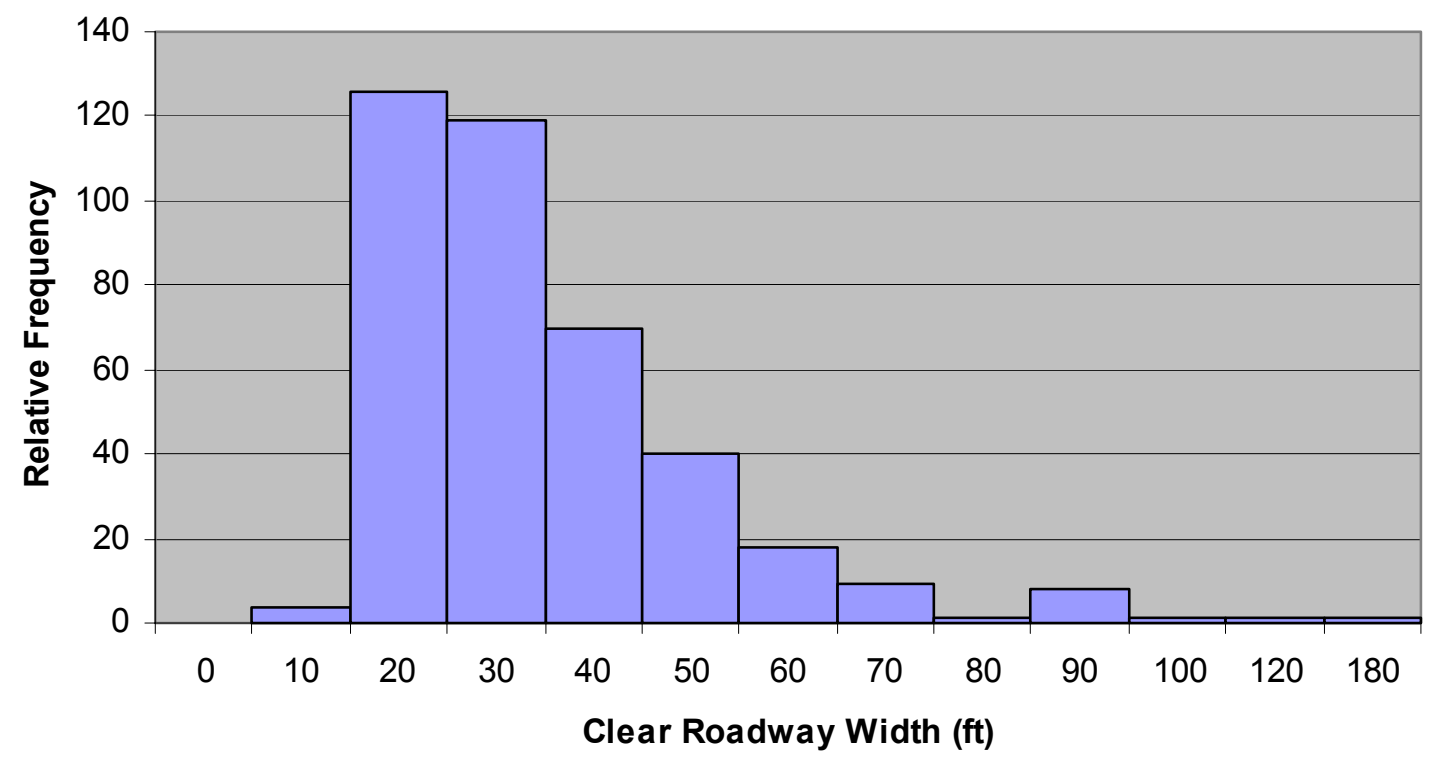

Figure 3.2. Histogram of relative frequency for clear roadway width 


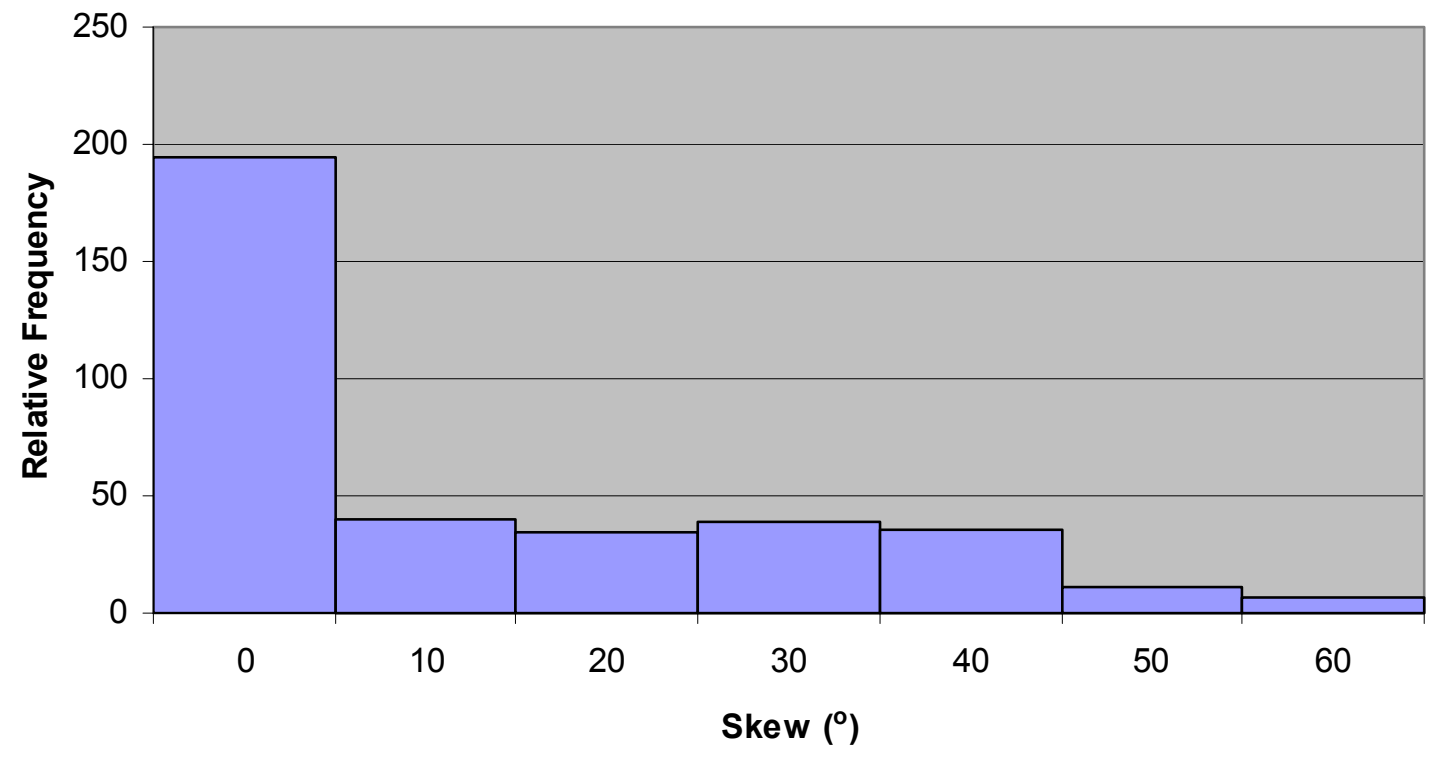

Figure 3.3. Histogram of relative frequency for skew

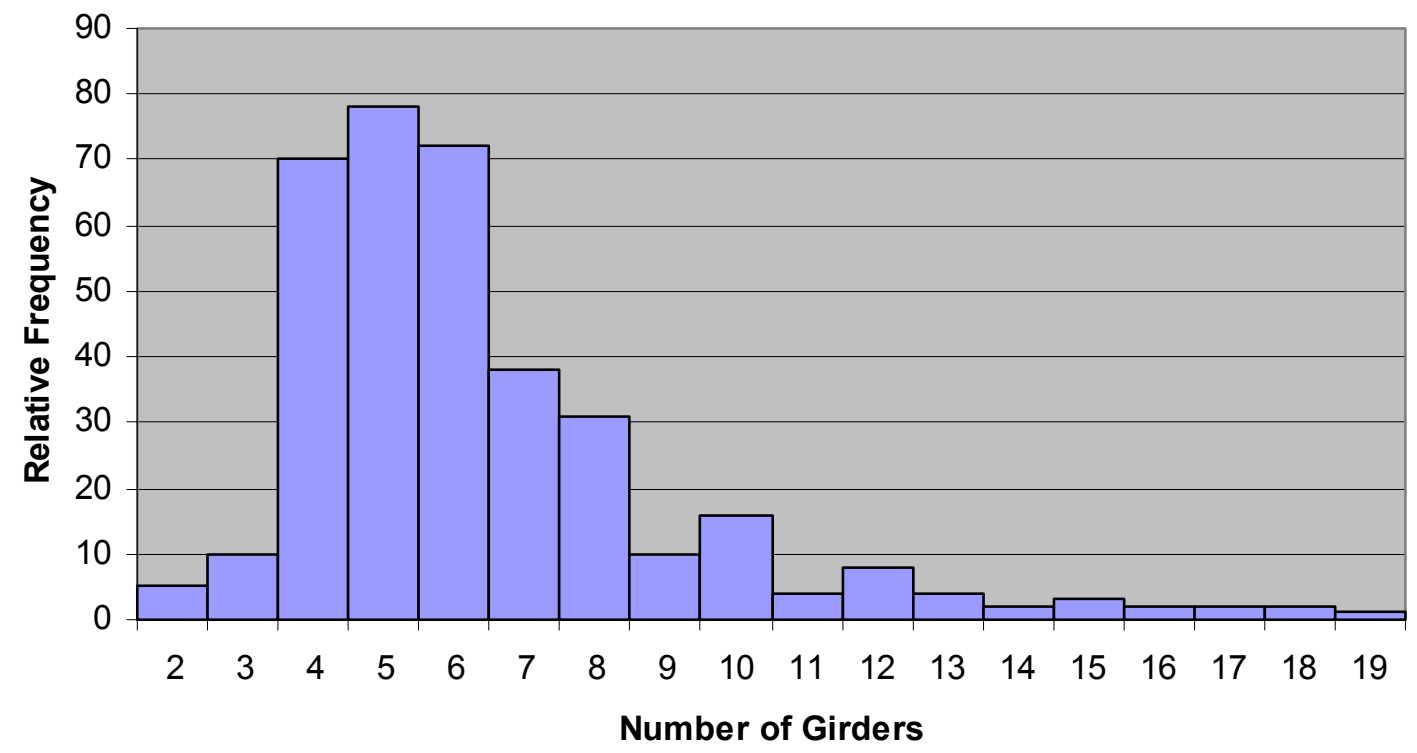

Figure 3.4. Histogram of relative frequency for number of girders 


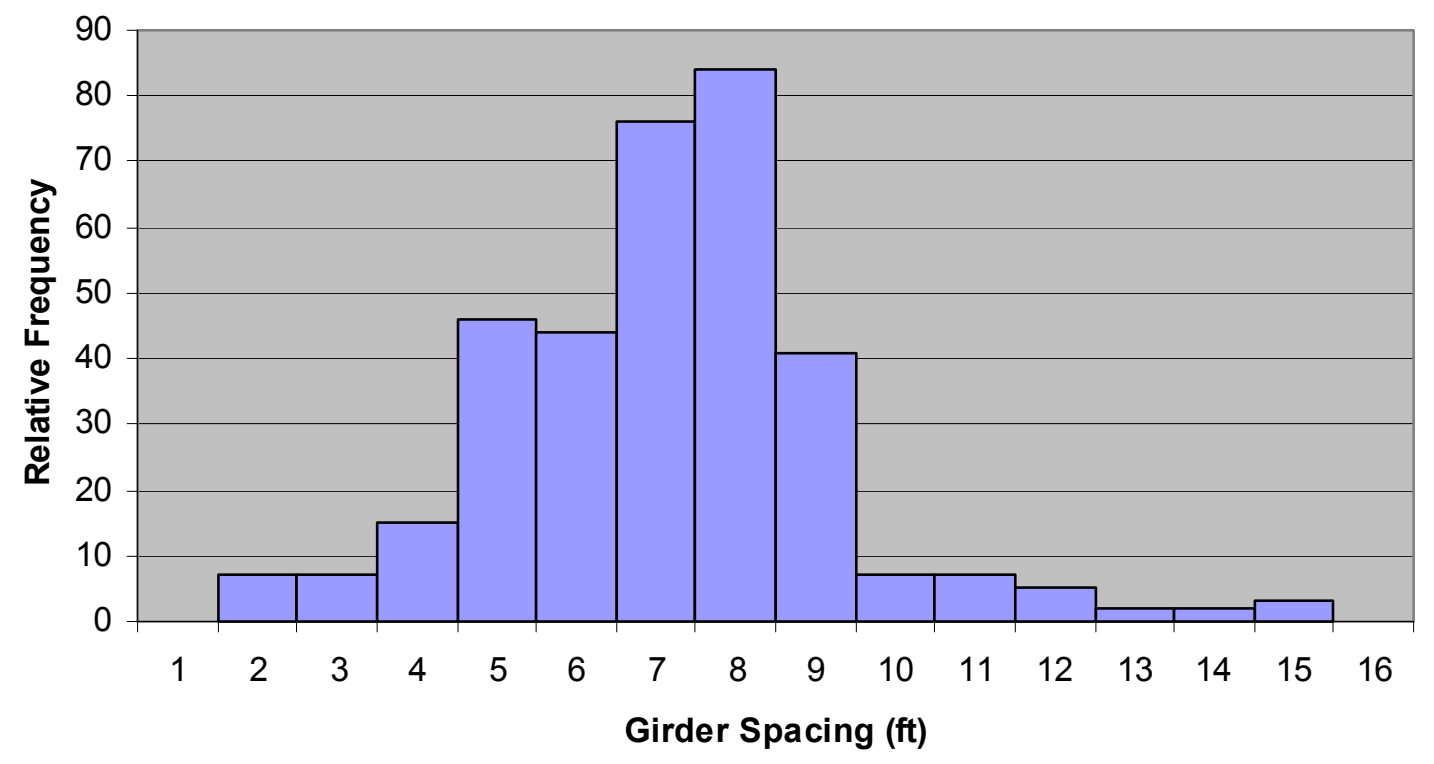

Figure 3.5. Histogram of relative frequency for girder spacing

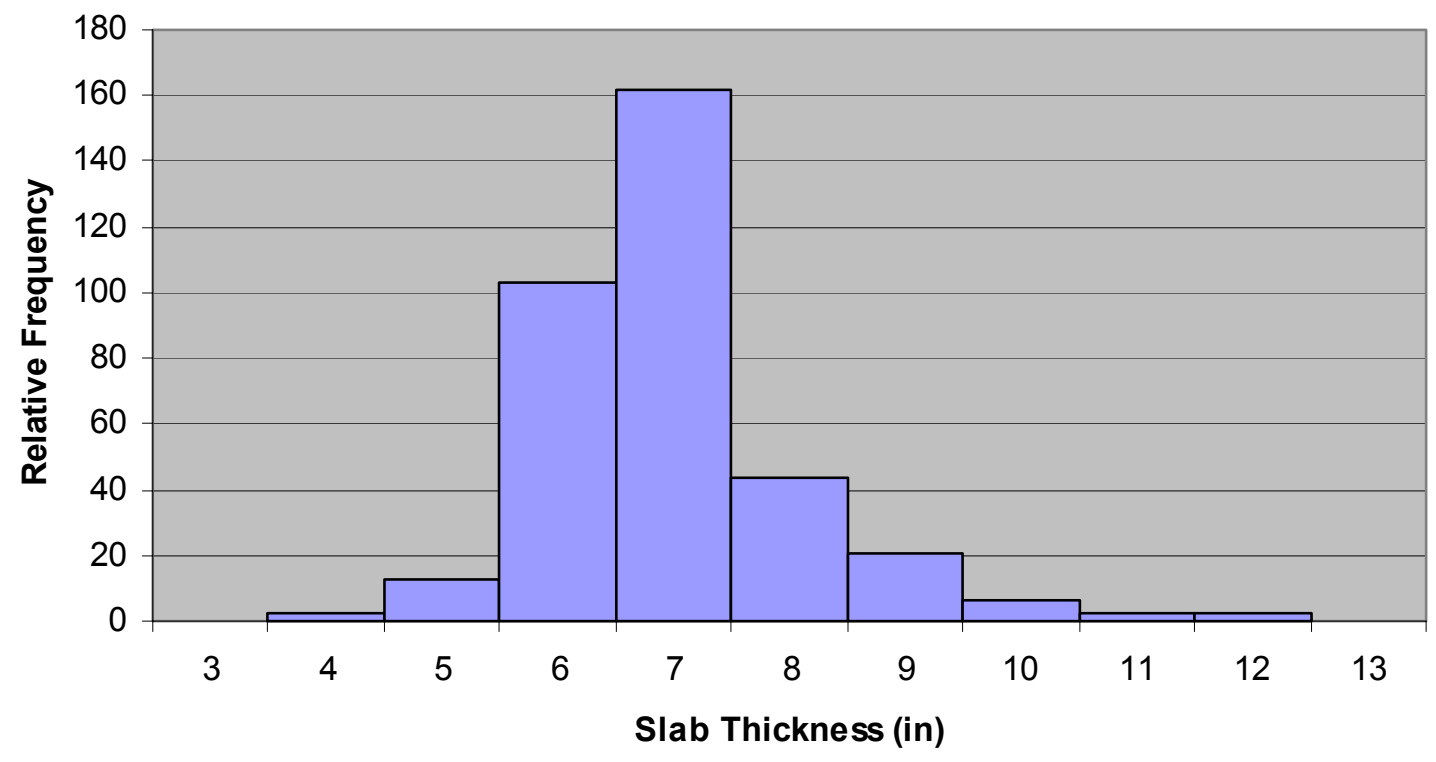

Figure 3.6. Histogram of relative frequency for slab thickness 


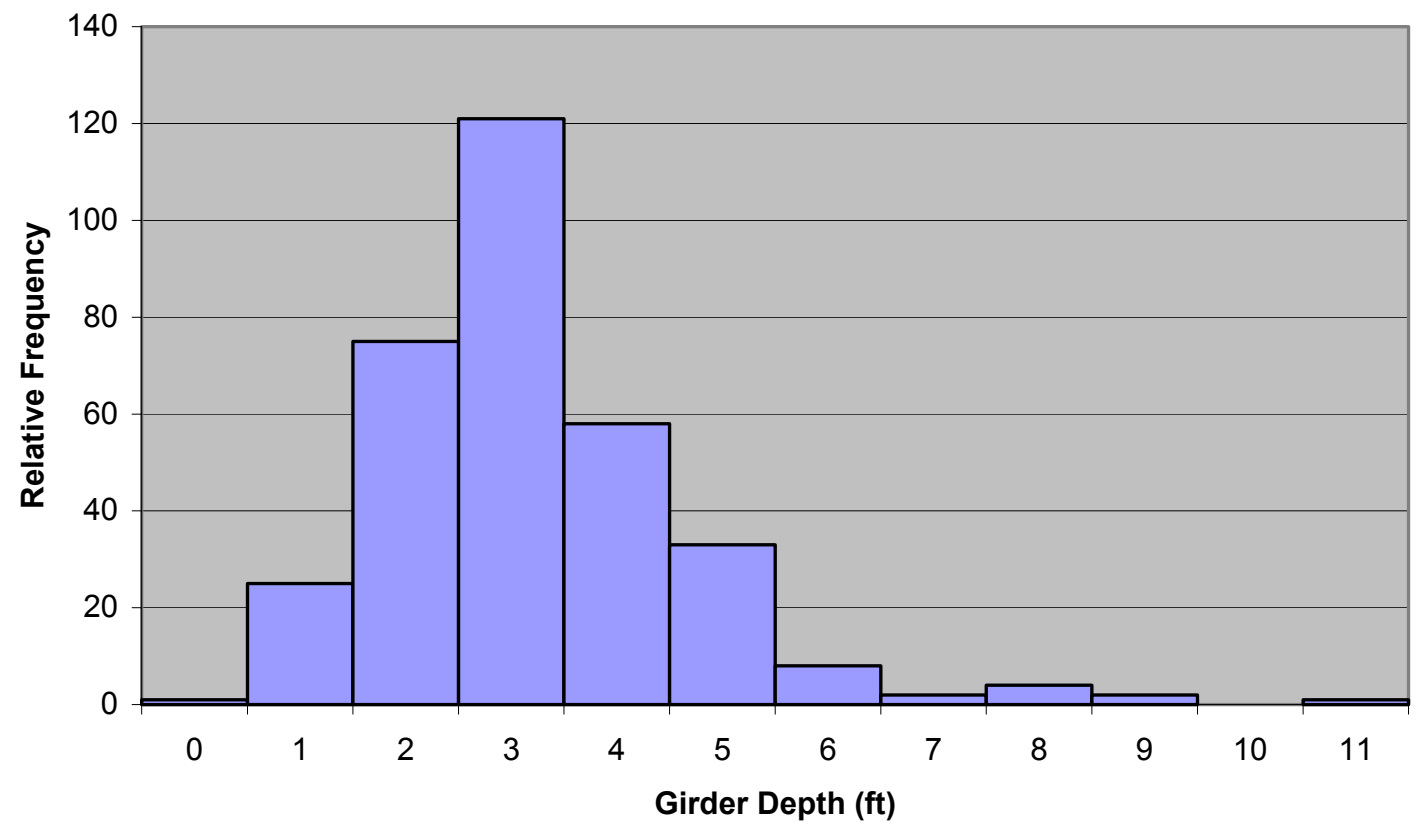

Figure 3.7. Histogram of relative frequency for girder depth

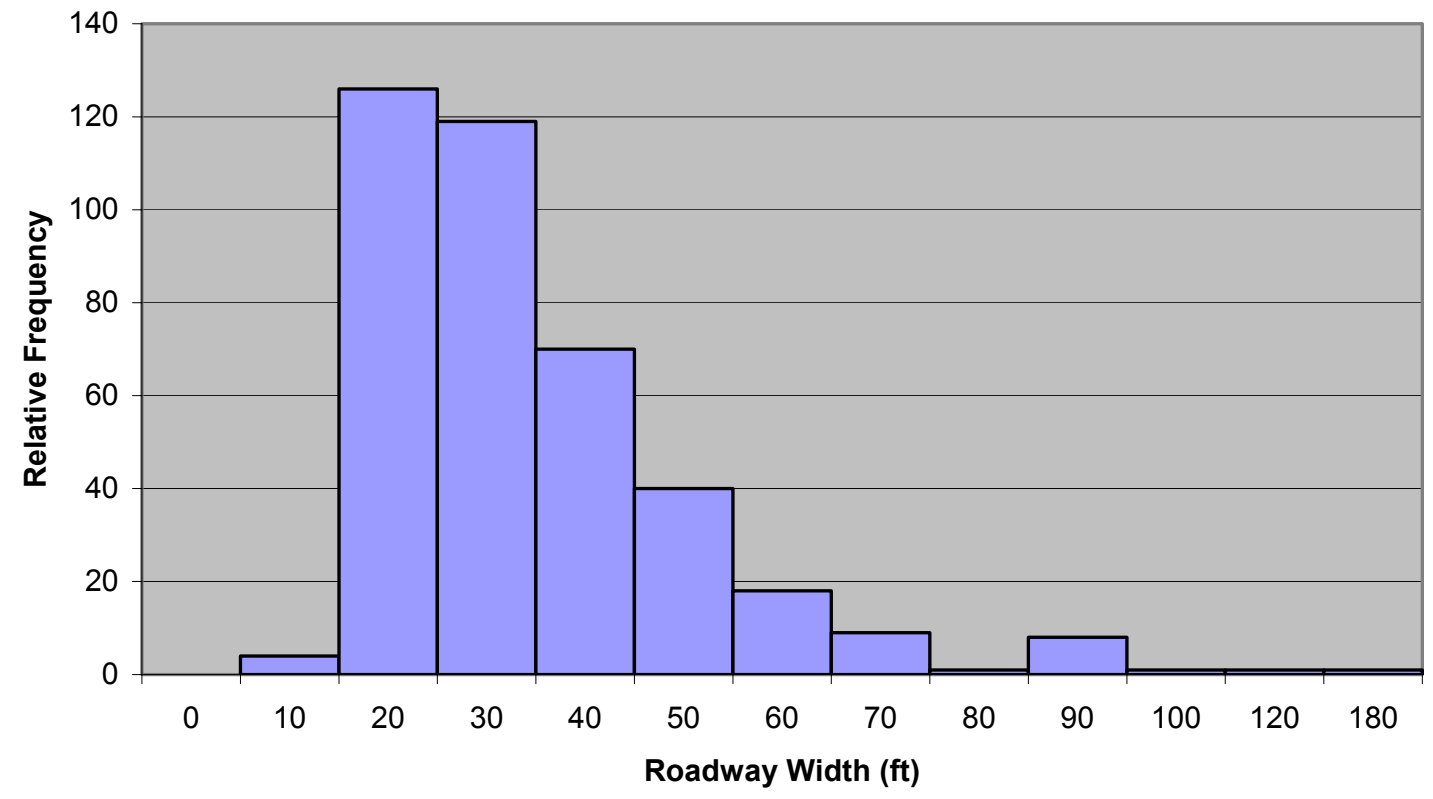

Figure 3.8. Histogram of relative frequency for roadway width (out-to-out) 


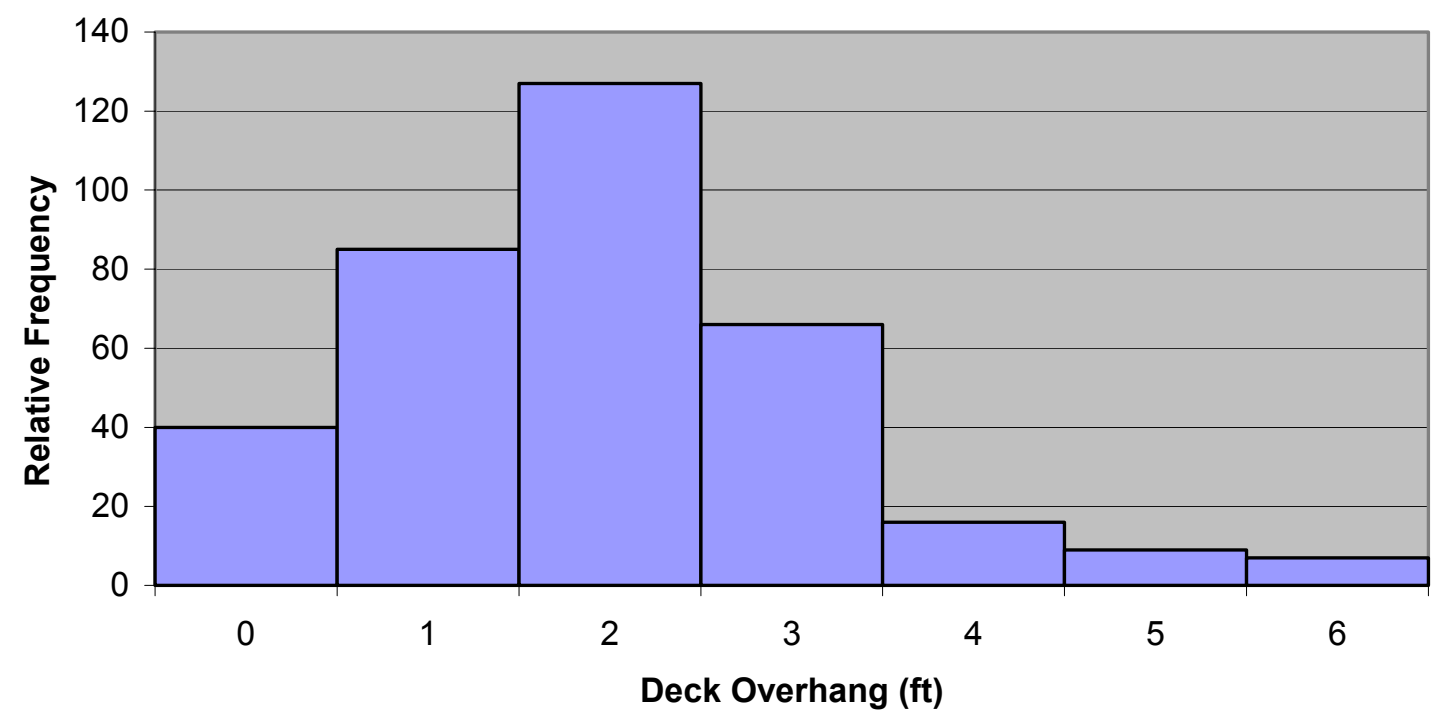

Figure 3.9. Histogram of relative frequency for deck overhang

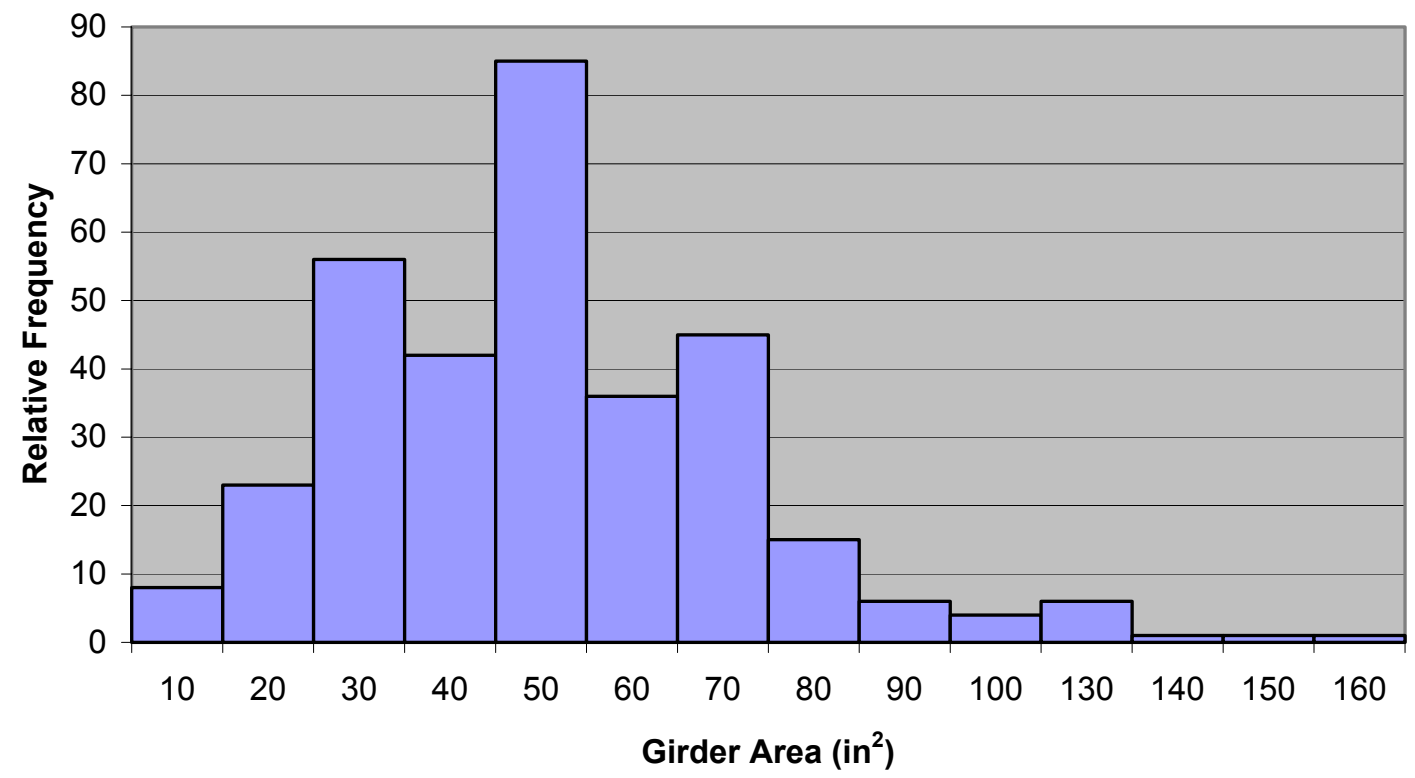

Figure 3.10. Histogram of relative frequency for girder area 


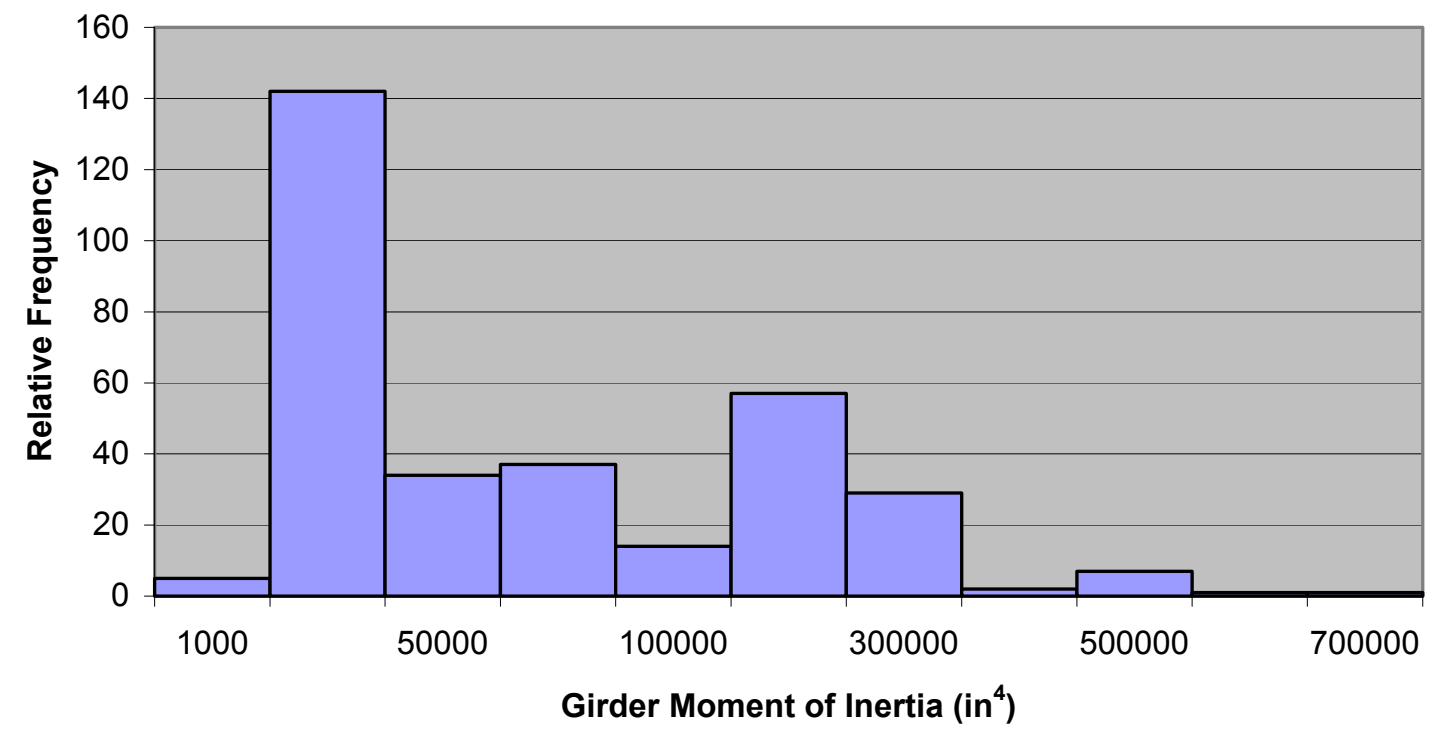

Figure 3.11. Histogram of relative frequency for girder moment of inertia

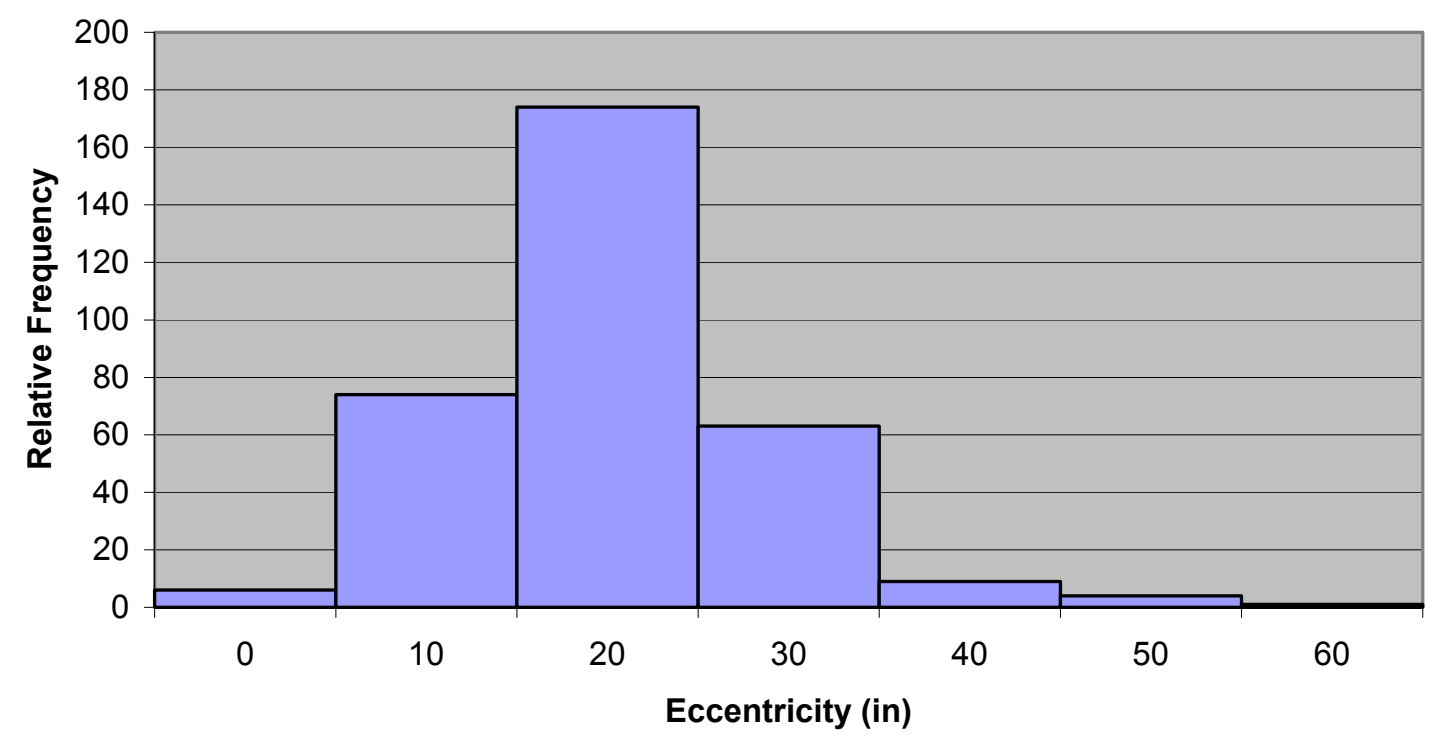

Figure 3.12. Histogram of relative frequency for eccentricity 


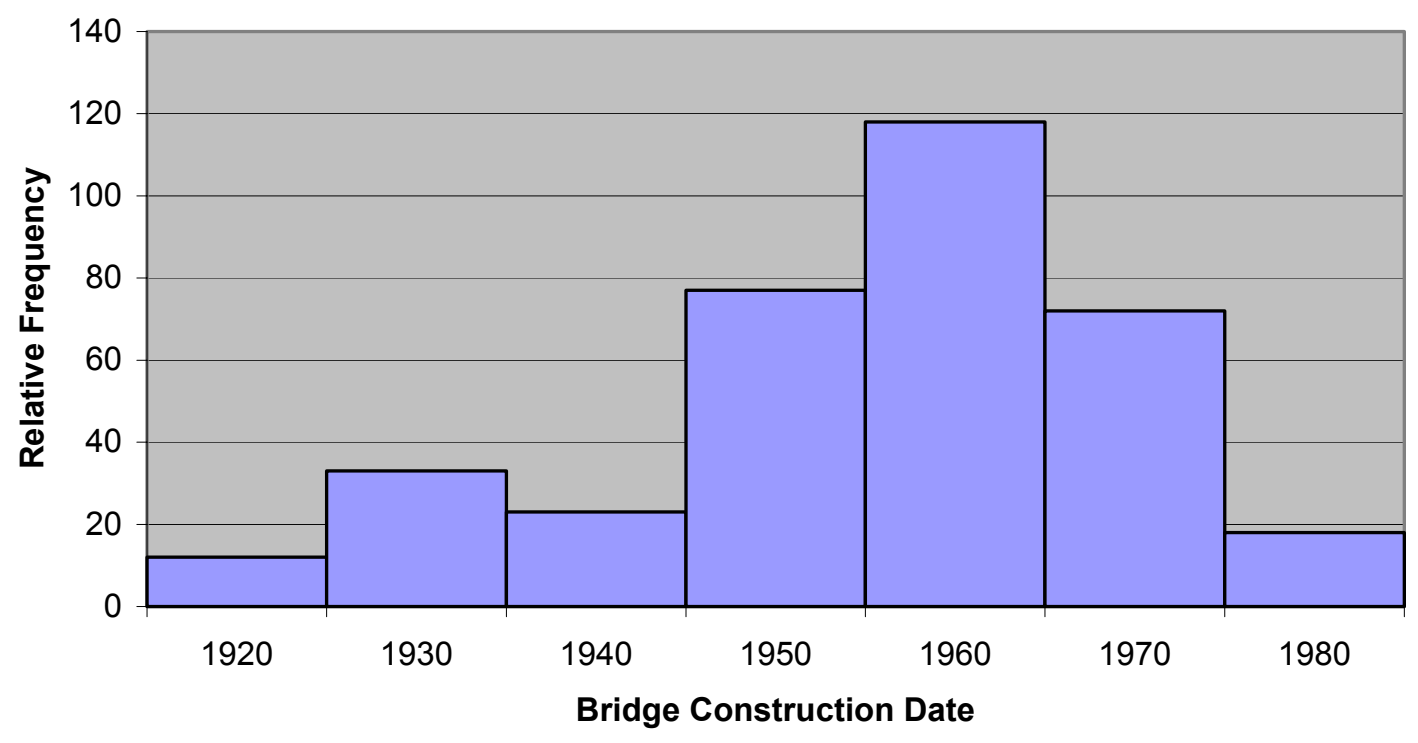

Figure 3.13. Histogram of relative frequency for bridge construction date

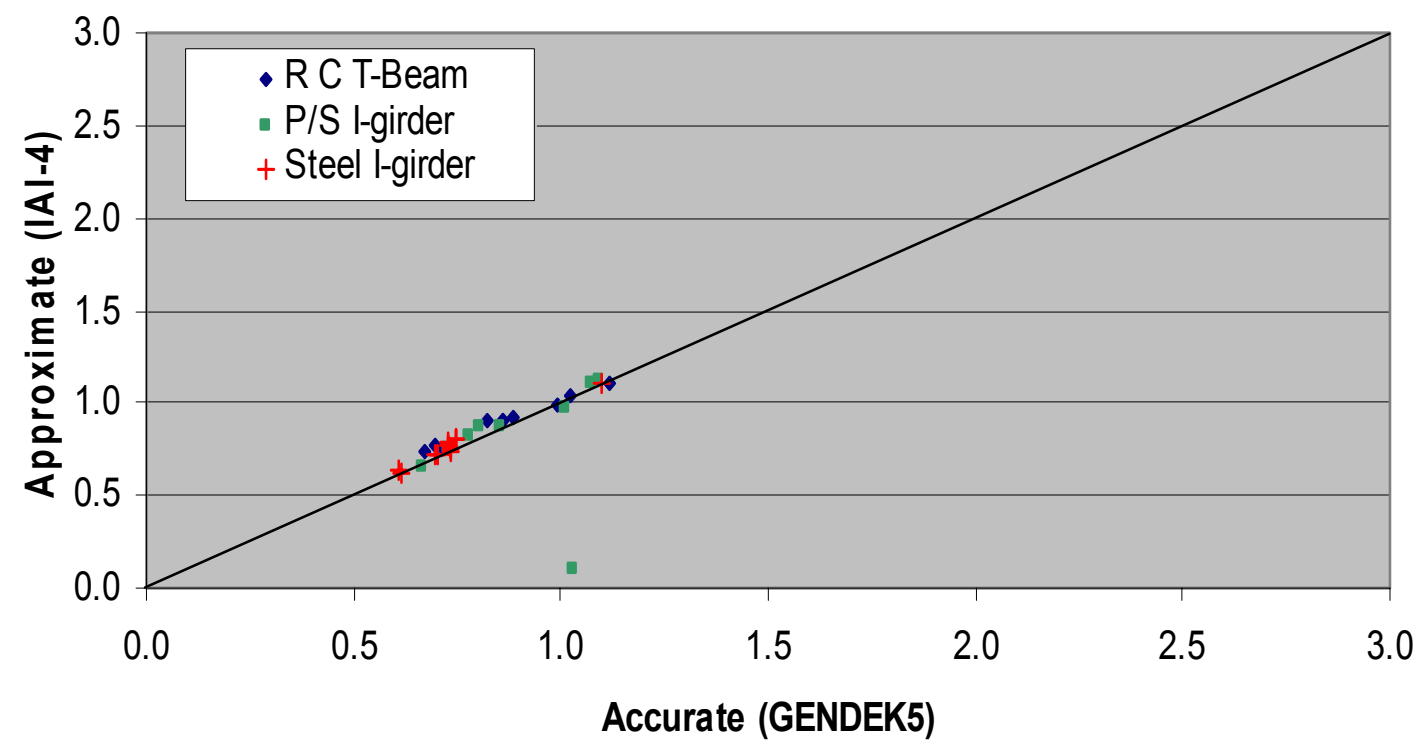

Figure 3.14. Comparison of proposed distribution factors vs. analytical results 


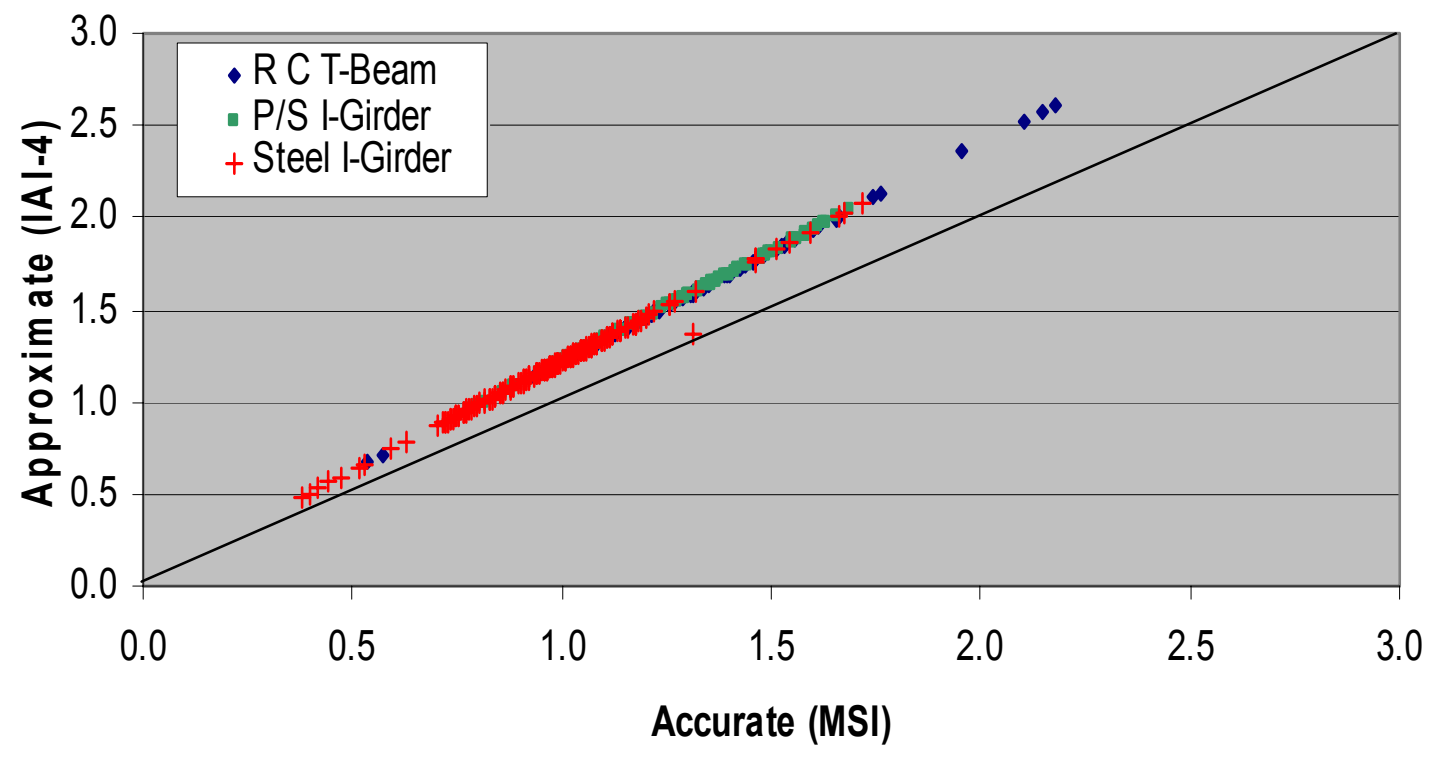

Figure 3.15. Comparison of proposed distribution factors vs. MSI results 


\section{CHAPTER 4}

\section{COMPUTATION OF DISTRIBUTION FACTORS FOR SLAB-ON-STEEL GIRDER BRIDGES}

\subsection{Introduction}

Literature gathered from previous research has provided many different procedures for computing live load distribution factors, which range from using bottom flange strains and stress to the summation of moments of each member of the system. This chapter presents several procedures developed and presented in archival literature for computing live load distribution factors. Analytical studies are also conducted to compare these procedures and example calculations are provided. The FEA tools used in the analytical studies are subsequently presented in Chapter 5 . The bridge used for comparisons and examples is a Federal Highway Administration (FHWA) test bridge discussed by Moore et al. (1990). Finally, the results for each procedure are then presented in comparison to the current specifications.

\subsection{Barker Method}

Barker et al. (1999) used two different methods to compute live load distribution factors using elastic moments and bottom flange stresses. The first method for computing load distribution factors, based on elastic moments, is shown in Eqn. 4.1. This was developed by Bakht (1988) for research done for the Ministry of Transportation of Ontario. The second method, shown in Eqn. 4.2, used the bottom flange stress at 
midspan of the girders along with the section modulii to compute load distribution factors.

\section{Barker Method One:}

Distribution Factor $=\frac{2 \cdot M_{i}^{\text {girder }}}{\sum_{i=1}^{n} M^{\text {girder }}}$

where $M_{i}^{\text {girder }} \quad=$ elastic moment of the girder

\section{Barker Method Two:}

Distribution Factor $=\frac{2 \cdot\left(\sigma^{\text {girder }} * S_{\text {girder }}^{A D I M}\right)}{\left(\sigma_{i}^{\text {girder }} \cdot S_{\text {girder }}^{A D I M}\right)+\sum\left(\sigma_{i} \cdot S_{i}\right)}$

$$
\begin{array}{cl}
\text { where } \sigma^{\text {girder }} & =\text { measured stress at bottom flange } \\
S_{i} & =\text { analytical section modulus with design } \\
& \text { dimensions } \\
S^{A D I M} & \text { analytical section modulus with measured } \\
& \text { dimensions }
\end{array}
$$

Barker uses three strain gauges, two placed in the web and one on the bottom

flange, to fit a curve that represents a linear stress profile through a given cross section (Barker et al; 1999). The least squares method is used to fit the line to the experimental results and can be best described by the following equation.

$$
\begin{aligned}
& {\left[\begin{array}{cc}
\sum \sigma_{i}^{2} & \sum \sigma_{i} \\
\sum \sigma_{i} & n
\end{array}\right] \cdot\left\{\begin{array}{l}
a \\
b
\end{array}\right\}=\left\{\begin{array}{c}
\sum d_{i} \sigma_{i} \\
\sum d_{i}
\end{array}\right\}} \\
& \text { where } \sigma_{i} \quad=\text { experimentally determined stress (ksi) } \\
& d_{i} \quad=\text { depth from the bottom of bottom flange (in) } \\
& a \quad=\text { slope of best fit line } \\
& b \quad=\text { neutral axis (in) }
\end{aligned}
$$

Figure 4.1 shows the representative location of the strain gauges, as well as the location of the neutral axis, $b$. Solving Eqn. 4.3 gives the following equation for a distance from 
the bottom flange (depth vs. stress value) to any given stress in the girder from the slope, $a$, and neutral axis, $b$, calculated in Eqn 4.3.

$$
\begin{aligned}
& d_{i}=a \cdot \sigma_{a}+b \\
& \sigma_{\mathrm{a}} \quad \begin{array}{l}
\text { stress after compensating for axial stresses at the neutral } \\
\text { axis }
\end{array}
\end{aligned}
$$

The elastic moment, $M_{i}$ (Eqn. 4.8) can be calculated from breaking the load carrying mechanism into three parts: the steel girder bending about its own neutral axis $\left(\mathrm{M}_{\mathrm{L}}\right)$, the reinforced concrete slab bending about its own neutral axis $\left(\mathrm{M}_{\mathrm{u}}\right)$, and a couple, Na, that is a function of the amount of composite action between the concrete area and steel section (Na) (Barker, 1999). These representative equations are provided below in Eqns. 4.5 to 4.7, while Fig. 4.2 presents a graphical explanation of how the experimental stresses are transformed in the three componets described above (Barker, 1999).

$$
\begin{aligned}
& \mathrm{M}_{\mathrm{L}}=\left(\sigma_{b f}-\sigma_{a}\right) \cdot S_{s t l} \\
& \mathrm{Mu}= M_{L} \cdot\left(\frac{E_{C} \cdot I_{C}}{E_{S} \cdot I_{S}}\right) \\
& \mathrm{Na}=\left(\sigma_{a}+A_{s t l}\right) \cdot a \\
& \mathrm{M}_{\mathrm{i}}= \mathrm{M}_{\mathrm{L}}+\mathrm{M}_{\mathrm{u}}+\mathrm{Na} \\
& \sigma_{\mathrm{bf}} \quad=\text { bottom flange stress after compensating for axial stresses } \\
& S_{\mathrm{stl}} \quad=\text { section modulus of the steel alone } \\
& E_{\mathrm{c}} \quad=\text { modulus of elasticity for concrete } \\
& E_{\mathrm{s}} \quad=\text { modulus of elasticity for steel } \\
& I_{\mathrm{c}} \quad=\text { Moment of Inertia of the concrete alone } \\
& I_{\mathrm{s}} \quad=\text { Moment of Inertia of the steel section alone } \\
& A_{\mathrm{stl}} \quad=\text { Area of the steel section }
\end{aligned}
$$


After the elastic moments for each girder are computed, the load distribution factor can be calculated from Eqn. 4.1. The equation is multiplied by 2 times the number of lines of wheels used in the loading to present the distribution factors in terms of the number of trucks.

Equation 4.2 involves the use of bottom flange stresses along with the short-term section modulus using both the actual and design dimensions of each girder in the system. The section modulus is computed from the following

$$
\mathrm{S}_{\mathrm{i}}=\frac{I_{b}}{b}
$$

$$
\begin{aligned}
\text { where } I_{i} & =\text { moment of inertia } \\
b & =\text { distance from neutral axis of the section to extreme } \\
& \text { fiber. }
\end{aligned}
$$

The moment of inertia for the cross sections can be obtained from information already available from previous data reduction of the experimental results, with the axial corrected depth vs. stress curve, and the flexural stress equation $\sigma=\frac{M c}{I}$ (Barker, 1999). The equation for moment of inertia is presented as

$$
I_{i}=-M_{i} \cdot a
$$

$$
\begin{array}{cl}
\text { where } M_{i} & =\text { elastic moment } \\
a & =\text { slope of the depth vs. stress curve. }
\end{array}
$$

From Eqn. 4.2, for the girder of interest, the bottom flange stress is multiplied by the actual dimensioned section modulus, $S_{A D I M}$. This value is then divided by the summation of the same stress and actual dimensioned section modulus along with the remaining stresses for the adjacent girder multiplied by their respective design dimensioned section modulus, $S_{i}$. The distribution factors are changed from line of wheels to trucks by multiplying by a factor of 2 times the number of lines of wheels used in the loading. 


\subsection{Stallings Method}

Stallings and Yoo (1991) performed a series of experimental field tests on three short span steel I-girder bridges with one and two lanes loaded to help evaluate the load capacity of the bridges and to assess the behavior of these bridges. One aspect investigated in this study was the computation of load distribution and the comparison to code specified equations. Equation 4.11, written in terms of bottom flange strain, was developed to compute the load distribution factor from recorded data taken in the experimental testing of the three bridges.

$$
\text { Distribution Factor }=\frac{\left(n \cdot \varepsilon_{i}\right)}{\left(\sum_{i=1}^{k} \varepsilon_{i} \cdot w_{i}\right)}
$$

$$
n=\text { number of wheel lines applied during loading }
$$

$\varepsilon_{\mathrm{i}}=$ strain at the midspan of the bottom flange of the $\mathrm{i}^{\text {th }}$ girder $w_{\mathrm{i}}=$ ratio of the girder section modulus of the $\mathrm{i}^{\text {th }}$ girder to girder section modulus of a typical interior girder

The load distribution factor was computed from Eqn. 4.11 by multiplying the number of wheel lines applied during the loading with the bottom flange strain recorded from the girder of interest. This was then divided by the summation of bottom flange strain recorded the ratio of steel section modulii for each girder. 


\subsection{Bakht Method}

Bakht presents a procedure similar to the AASHTO Standard Specification equation of $\frac{S}{D_{d f}}$, where $\mathrm{S}$ is the girder spacing and $D_{\mathrm{df}}$ is the design factor associated with the type of bridge superstructure. The design factor, $D_{\mathrm{df}}$, can be computed using Bakht's procedure from bottom flange strains recorded at the location of maximum moment due to the applied loading. The procedure described below was utilized in the development of the live load distribution factors adopted in Ontario Highway Bridge Design Code (OHBDC, 1991).

The design factors defined in the OHBDC were developed using an orthotropic plate procedure determining a design factor, $D_{\mathrm{df}}$, based on the intensity of the transverse distribution of moments. The OHBDC equation for load distribution factors was developed from the parameters of girder spacing and span length. Additionally, the OHBDC incorporated a correction factor that was used to account for the number of lanes loaded, design lane width, and type of bridge superstructure.

The load distribution factor was calculated in this procedure from:

$$
\text { Distribution Factor }=\frac{S}{D_{d f}}
$$

where $\mathrm{S}$ is the girder spacing (in units of length) and $D_{\mathrm{df}}$ is the design factor (in consistent units of length). The design factor is computed from Eqn. 4.13 by multiplying the girder spacing divided by number of lines of wheels applied during the loading with the summation of bottom flange stains recorded from experimental testing divided by the 
recorded bottom flange strain of the girder of interest.

$$
\begin{aligned}
D_{d f}=\left(\frac{S}{n}\right) \cdot\left(\frac{\sum \varepsilon_{i}}{\varepsilon_{\max }}\right) & \text { (Eqn. 4.13) } \\
D_{\mathrm{df}}= & \text { design factor, } \mathrm{ft} \\
S & =\text { girder spacing, } \mathrm{ft} \\
n & =\text { number of lines of wheels applied during loading } \\
\varepsilon_{\max } & =\begin{array}{l}
\text { maximum strain created due to loading (at the loaded } \\
\text { girder) }
\end{array} \\
\varepsilon_{\mathrm{i}} & =\text { strain at the } \mathrm{i}^{\text {th }} \text { girder }
\end{aligned}
$$

The calculation for the load distribution factor presented in Eqn. 4.12 can be completed upon the computation of the design factor provided in Eqn. 4.13.

\subsection{Mabsout Method}

Mabsout (1997) calculated live load distribution factors for a system of girders from the moment computed from a finite element analysis of the 3D bridge at a critical section divided by the moment computed from a line of wheels of an HS20 truck applied to a single girder, as analyzed in a typical 2D line girder analysis, as shown in Eqn. 4.14.

$$
\text { Distribution Factor }=\frac{M^{\text {FEA }}}{M^{\text {TRUCK }}}
$$

The FEA moments for a proposed critical effective section, consisting of elements from the deck, and girder web and flanges, was used to compute the total moment of the section, $M^{F E A}$. The deck was assumed to have an effective width of $\frac{S}{2}$ on each adjacent side of the girder of interest. The moments were computed, using Eqn. 4.15, for every element included in the critical section. 


$$
M^{F E A}=\sum_{i=1}^{n} \sigma_{i} \cdot \text { Area }_{i} \cdot c_{i}
$$

$$
\begin{array}{ll}
\text { where } \sigma_{i} & =\text { stress obtained from the FEA output for } \mathrm{i}^{\text {th }} \\
& \text { element } \\
\text { Area }_{i} & =\text { area of the } \mathrm{i}^{\text {th }} \text { element } \\
c_{i} & =\text { distance of the neutral axis to the } \mathrm{i}^{\text {th }} \text { element }
\end{array}
$$

As shown in Eqn. 4.15, the FEA moment was computed for each element in the critical section by multiplying the stress in the element found in the FEA output data, $\sigma$, the area of the element, and the distance of the element from the neutral axis, $c$. The neutral axis was determined by locating the point of zero stress from the stress profile provided in the FEA output data. From the summation of these moments the total moment for the FEA model, $\mathrm{M}^{\mathrm{FEA}}$, was computed for the assumed effective section. The moment, $\mathrm{M}^{\mathrm{TRUCK}}$, is determined by calculating the maximum moment for a line girder subjected to a single line of wheels (see Fig. 4.7). Equation 4.14 is used to compute the load distribution factor for the FEA bridge model by dividing the previously calculated $M^{F E A}$ with $M^{T R U C K}$.

\subsection{Example Calculations}

This section uses results from the analysis of an AISI-FHWA scale model laboratory bridge (Moore et al., 1990) to demonstrate the calculation of the live load distribution factors using the previously described methods.

The AISI-FHWA bridge consists of a 2-span continuous structure with equal $56 \mathrm{ft}$ spans. The cross section of the $19 \mathrm{ft} .-2 \frac{3}{8}$ in. wide bridge is comprised of a 4 in. concrete deck supported by 3 steel plate girders with $6 \mathrm{ft} .-9 \frac{5}{8}$ in. spacing and $2 \mathrm{ft}$. -9 
$9 / 16$ in. overhangs. Figure 4.5 shows a cross-section for the AISI-FHWA bridge and Figs. 4.5 and 4.6 show the elevation and girder sizes respectively.

The loading case used to demonstrate the previously described distribution factor procedures consists of 3 simulated lanes (see Fig. 4.6) each comprised of two 16.6 kip wheel loads with an axle spacing of $2 \mathrm{ft} .-4^{13} / 16$ in. In the actual testing, the loading was performed by moving a single $16.6 \mathrm{kip}$ load to each of the wheel load positions shown in Fig. 4.6 and superposition was used to assess the experimental distribution factors. In the FEA modeling, all wheel loads were applied simultaneously. The 3-lane loaded load pattern was applied at the $0.4 \mathrm{~L}$ point with the stress/strain data from the $0.4 \mathrm{~L}$ point used to determine the maximum positive bending distribution factor and at the $0.6 \mathrm{~L}$ point with the stress/strain data from $5 \mathrm{ft}$. in of the 1.0L point used to determine the maximum negative bending distribution factor.

The analytical results used in these calculations were obtained using the commercial packages FEMap (1999) and ABAQUS v.6.3.1 (2002) to conduct a refined 3D analytical model of the example bridge. A detailed discussion of this FEA modeling along with extensive model validation studies using both experimental data along with the analytical results of others is presented subsequently in Chapter 5.

\subsubsection{Barker Method 1 for Positive Moment Region}

The elastic moment calculation requires an equation for the location of the neutral axis. The equation is derived from Eqn. 4.3 using the following matrix with all the data 
needed to solve this matrix found in Table 4.1.

$$
\left[\begin{array}{cc}
\sum \sigma_{i}^{2} & \sum \sigma_{i} \\
\sum \sigma_{i} & n
\end{array}\right] \cdot\left\{\begin{array}{l}
a \\
b
\end{array}\right\}=\left\{\begin{array}{c}
\sum d_{i} \sigma_{i} \\
\sum d_{i}
\end{array}\right\}
$$

Solving this matrix gives the following equation

$$
\begin{aligned}
& \mathrm{d}_{\mathrm{i}}=a \cdot \sigma_{a}+b \\
& \mathrm{~d}_{\mathrm{i}}=3.45875 \cdot \sigma_{a}+4.6117 .
\end{aligned}
$$

By setting $\sigma_{\mathrm{a}}$ equal to zero, the neutral axis can be determined for the girder of interest.

$$
\mathrm{y}_{1}=4.6117 \text { in }
$$

The neutral axis location is now used to calculate a (the distance of from the bottom of the bottom flange to the neutral axis) along with the stress and the neutral axis and area of the steel section for use in Eqn. 4.7 to compute the Na value. Equation 4.5 is computed for $\mathrm{M}_{\mathrm{L}}$ using the stress obtained at the bottom flange minus the stress at the neutral axis multiplied by the steel section modulus from Eqn. 4.9. The moment caused by the reinforced concrete slab bending about its own neutral axis, $\mathrm{M}_{\mathrm{u}}$ can be calculated by multiplying the corresponding $\mathrm{M}_{\mathrm{L}}$ computed in Eqn. 4.5 by the ratio of the modulus of elasticity and moment of inertia for the concrete over steel as seen in Eqn. 4.7. The elastic moment, $M_{i}$, of each girder is then computed by the summation of $M_{L}, M_{u}$, and $\mathrm{Na}$. 
Girder 1:

$$
\begin{aligned}
& \mathrm{M}_{\mathrm{L}}=(18.254-0) \cdot 102=1861.9 \text { in-kips } \\
& \mathrm{M}_{\mathrm{u}}=1861.9 \cdot\left(\frac{4000 \cdot 256}{29000 \cdot 427.4}\right)=153.8 \text { in-kips } \\
& \mathrm{Na}=(0 \cdot 11.25) \cdot 4.6117=0 \text { in-kips } \\
& \mathrm{M}_{\mathrm{i}}=1861.9+153.8+0=2016 \text { in-kips }
\end{aligned}
$$

Girder 2:

$$
\begin{aligned}
& \mathrm{M}_{\mathrm{L}}=(25.1715-0) \cdot 102=2567.5 \text { in-kips } \\
& \mathrm{M}_{\mathrm{u}}=2567.5 \cdot\left(\frac{4000 \cdot 256}{29000 \cdot 427.4}\right)=212.1 \text { in-kips } \\
& \mathrm{Na}=(0 \cdot 11.25) \cdot 4.6117=0 \text { in-kips } \\
& \mathrm{M}_{\mathrm{i}}=2567.5+212.1+0=2780 \text { in-kips }
\end{aligned}
$$

Girder 3:

$$
\begin{aligned}
& \mathrm{M}_{\mathrm{L}}=(25.1715-9.8956) \cdot 102=1558.1 \text { in-kips } \\
& \mathrm{M}_{\mathrm{u}}=1558.1 \cdot\left(\frac{4000 \cdot 256}{29000 \cdot 427.4}\right)=128.7 \text { in-kips } \\
& \mathrm{Na}=(9.8956 \cdot 11.25) \cdot 4.6117=513.4 \text { in-kips } \\
& \mathrm{M}_{\mathrm{i}}=1558.1+128.7+513.4=2200 \text { in-kips }
\end{aligned}
$$

The total girder moments for each respective girder may now be incorporated into Eqn. 
4.3 to determine the maximum positive bending live load distribution factor

$$
\text { Distribution Factor }=\frac{2780}{(2016+2780+2200)} \cdot 2 \cdot 3 \quad \text { (Eqn. 4.1) }
$$

The distribution factor for the positive moment region using Barker Method 1 is

$$
\text { Distribution Factor }=\mathbf{2 . 3 8 4}
$$

\subsubsection{Barker Method 1 for Negative Moment Region}

The computation of $\mathrm{M}_{\mathrm{L}}, \mathrm{M}_{\mathrm{u}}, \mathrm{N}_{\mathrm{a}}$, and $\mathrm{y}_{1}$ is completed using the procedures described in Section 4.6.1 as shown below.

$$
\begin{aligned}
& \mathrm{d}_{\mathrm{i}}=3.45875 \cdot \sigma_{a}+4.6117 \\
& \mathrm{y}_{1}=4.6117 \text { in }
\end{aligned}
$$

Girder 1:

$$
\begin{aligned}
& \mathrm{M}_{\mathrm{L}}=(8.95-0) \cdot 179=1602.1 \text { in-kips } \\
& \mathrm{M}_{\mathrm{u}}=1602.1 \cdot\left(\frac{4000 \cdot 256}{29000 \cdot 434.8}\right)=130.1 \text { in-kips } \\
& \mathrm{Na}=(0 \cdot 11.25) \cdot 4.6117=0 \text { in-kips } \\
& \mathrm{M}_{\mathrm{i}}=1602.1+130.1+0=1732 \text { in-kips }
\end{aligned}
$$


Girder 2:

$$
\begin{aligned}
& \mathrm{M}_{\mathrm{L}}=(13.338-0) \cdot 179=2387.5 \text { in-kips } \\
& \mathrm{M}_{\mathrm{u}}=2387.5 \cdot\left(\frac{4000 \cdot 256}{29000 \cdot 434.8}\right)=193.9 \text { in-kips } \\
& \mathrm{Na}=(0 \cdot 11.25) \cdot 4.6117=0 \text { in-kips } \\
& \mathrm{M}_{\mathrm{i}}=2387.5+193.9+0=2581 \text { in-kips }
\end{aligned}
$$

Girder 3:

$$
\begin{aligned}
& \mathrm{M}_{\mathrm{L}}=(8.95-0) \cdot 179=1602.1 \text { in-kips } \\
& \mathrm{M}_{\mathrm{u}}=1602.1 \cdot\left(\frac{4000 \cdot 256}{29000 \cdot 434.8}\right)=130.1 \text { in-kips } \\
& \mathrm{Na}=(0 \cdot 25.406) \cdot 4.6117=0 \text { in-kips } \\
& \mathrm{M}_{\mathrm{i}}=1602.1+130.1+0=1732 \text { in-kips }
\end{aligned}
$$

The total girder moments for each respective girder may now be incorporated into Eqn. 4.3 to determine the maximum positive bending live load distribution factor

$$
\text { Distribution Factor }=\frac{2581}{(1732+2581+1732)} \cdot 2 \cdot 3
$$

The distribution factor for the negative moment region using the Barker Method 1is

Distribution Factor $=\mathbf{2 . 5 6 2}$. 


\subsubsection{Barker Method 2 for Positive Moment Region}

The second procedure described in Section 4.2 was used to calculate the load distribution factor in this example for the positive moment region with the use of Eqn. 4.9 and 4.2. The section modulus of each section was computed in Eqn. 4.9 and stress values from Table 6.1 are applied to Eqn. 4.9 along with previously mentioned section modulii of each girder

$$
\text { Distribution Factor }=\frac{2 \cdot(25.1715 \cdot 149)}{(25.1715 \cdot 149)+\sum((18.2540 \cdot 150) \cdot 2)} \quad(\text { Eqn. 4.2). }
$$

Distribution Factor $=0.813$

This distribution factor must then be multiplied by the number of trucks applied during the loading, as seen on Fig. 4.4.

Distribution Factor $=3$ trucks $\cdot 0.850$

The distribution factor for the positive moment region using the Barker Method 2 is

$$
\text { Distribution Factor }=\mathbf{2 . 4 3 9} \text {. }
$$

\subsubsection{Barker Method 2 for Negative Moment Region}

The same procedure was followed as described in Section 4.6.3 for computation 
of load distribution factors for the negative moment region using Equations 4.9 and 4.2.

$$
\text { Distribution Factor }=\frac{2 \cdot(-13.338 \cdot 610)}{(-13.338 \cdot 610)+\sum((-8.95 \cdot 615) \cdot 2)}
$$

$$
\text { Distribution Factor }=0.850
$$

Again, the distribution factor computed must again be multiplied by the number of trucks applied during the loading.

$$
\text { Distribution Factor }=3 \text { trucks } \cdot 0.850
$$

The distribution factor for the negative moment region using Barker Method 2 is

$$
\text { Distribution Factor }=\mathbf{2 . 5 5 0} \text {. }
$$

\subsubsection{Stallings Method for Positive Moment Region}

The load distribution factor is computed using the Stallings procedure with the use of Eqn. 4.10 described in Section 4.3 using bottom-flange strains obtained for the girders and the results are found in Table 4.1. Figure 4.4 shows three lanes of trucks are applied for this loading case, creating six wheel lines this particular bridge. All exterior and interior girders have the same cross-section provided in Fig. 4.3, therefore, the ratio of the girder section modulus of the $\mathrm{i}^{\text {th }}$ girder to the section modulus of the interior girder is equal to one. The distribution factor can now be computed from Eqn. 4.11 as 
demonstrated below

$$
\text { Distribution Factor }=\frac{(6 \cdot 0.0009416)}{\left(\sum(0.0006632+0.0009416+0.0006632)\right.}
$$

The distribution factor for the positive moment region using the Stallings Method is:

$$
\text { Distribution Factor }=\mathbf{2 . 4 9 1}
$$

\subsubsection{Stallings Method for Negative Moment Region}

Using the same procedures as described in Section 4.6.5 and Equation 4.11, the load distribution factor for the negative moment region using the Stalling procedure is

$$
\text { Distribution Factor }=\frac{(6 \cdot 0.0001487)}{\left(\sum(0.0001004+0.0001487+0.0001000)\right.}
$$

The distribution factor for the negative bending region using the Stallings Method is

$$
\text { Distribution Factor }=\mathbf{2} .556 \text {. }
$$

\subsubsection{Bakht Method for Positive Moment Region}

Equation 4.13 given in Section 4.4 computes the design factor girder spacing, number of wheel lines applied during the loading, and bottom-flange strains, similar to the Stallings procedure described in Section 4.6.5. The first parameter, $\frac{S}{n}$, can be 
computed by taking the girder spacing found in Fig 4.3 and dividing it by an the number of wheel lines applied for the loading. The summation of recorded strains for each girder is divided by the strain of the girder of interest, and this terms are then multiplied together to calculate the load distribution applied the structure, as shown below using Eqn. 4.13

$$
\begin{aligned}
& D_{d f}=\left(\frac{6.8021}{6}\right) \cdot\left(\frac{\sum(0.0006632+0.0009416+0.0006632)}{0.0009416}\right) \\
& D_{d f}=2.731 \mathrm{ft} .
\end{aligned}
$$

The distribution factor is the calculated using the using Eqn. 4.11 where $S$ is the girder spacing and the design value, $D_{d f}$, was solved previously. Equation 4.12 yields

$$
\begin{aligned}
& \text { Distribution Factor }=\frac{S}{D_{d f}} \\
& \text { Distribution Factor }=\frac{6.8021 \mathrm{ft}}{2.731 \mathrm{ft}} .
\end{aligned}
$$

The distribution factor for the positive moment region using the Bakht Method is

$$
\text { Distribution Factor }=2.491 \text {. }
$$

\subsubsection{Bakht Method for Negative Moment Region}

The procedure for the negative moment region utilizing the Bakht procedure is identical to the described calculation described in Section 4.6.7, and using Eqns. 4.12 and 4.13 


$$
\begin{aligned}
D_{d f} & =\left(\frac{6.8021}{6}\right) \cdot\left(\frac{\sum(0.0001004+0.0001487+0.0001000)}{0.001487}\right) \\
D_{d f} & =2.662 .
\end{aligned}
$$

This distribution factor Eqn. 4.12 yields

$$
\begin{aligned}
& \text { Distribution Factor }=\frac{S}{D_{d f}} \\
& \text { Distribution Factor }=\frac{6.8021 \mathrm{ft}}{2.662 \mathrm{ft}} .
\end{aligned}
$$

The distribution factor for the negative moment region using the Bakht Method is:

$$
\text { Distribution Factor }=\mathbf{2 . 5 5 6}
$$

\subsubsection{Mabsout Method for Positive Bending Region}

The Mabsout Method computes the distribution factor by summing the moments of slab, flange, and web sections. Using Eqn. 4.15, the moment of each element is computed by multiplying the stress values obtained from FEA output by the area of the element and the distance from the neutral axis as shown in Table 4.2 for every element in the proposed effective section. The moments were summed to obtain the total moment on the section, $M^{F E A}$, caused by the applied loading. CONSYS (2000) was used to determine the maximum moment, $M^{\text {TRUCK }}$, applied to a girder by one line of wheels from the truck used. The calculated moments are

$$
\begin{aligned}
& M^{F E A}=8708 \text { in-kips } \\
& M^{\text {TRUCK }}=4147 \text { in-kips. }
\end{aligned}
$$


The distribution factor is computed by inserting the calculated values into Eqn. 4.14

$$
\text { Distribution Factor }=\frac{8708}{4147}
$$

Mabsout Method provides a distribution factor for the positive moment region of

$$
\text { Distribution Factor }=\mathbf{2 . 1 0 0} \text {. }
$$

\subsubsection{Mabsout Method for Negative Moment Section}

The same procedure as described in Section 4.6.11 is used along with Eqn. 4.15 to determine the load distribution factor for the negative moment region.

$$
\begin{aligned}
& M^{F E A}=2948 \text { in-kips } \\
& M^{\text {TRUCK }}=1278 \text { in-kips }
\end{aligned}
$$

Equation 4.13 yields the form

$$
\text { Distribution Factor }=\frac{2948}{1278}
$$

The distribution factor for the negative moment region using the Mabsout Method is

$$
\text { Distribution Factor }=\mathbf{2 . 3 0 8}
$$

\subsection{Comparisons}

The previous sections in this chapter presented an overview of various methods developed to compute live load distribution factors from both experimental and analytical data. Further, example calculations were presented based on the controlled load testing 
and subsequent analytical modeling of a large scale test conducted by the FHWA (Moore et al., 1990). Summary results for these comparisons are presented in Table 4.4. This table shows that the Barker methods 1 and 2, Stallings method, and the Bakht all predict relatively similar distribution factors while they are approximately $17 \%$ higher than the experimentally determined distribution factors. While the Mabsout method was found to produce a distribution factor that was within $7 \%$ of the experimental distribution factor, this procedure requires the use of an assumed effective section. As the Bakht procedure is relatively straightforward in its application, it is based on no assumed section properties, and has been used in the development and verification of the OHBDC distribution factors. This procedure will be employed in subsequent tasks in this study requiring the computation of live load distribution. 
Table 4.1. Bottom-flange strains, stresses, and D values for AISI-FHWA bridge calculations

\begin{tabular}{|c|c||c||c|c|c|}
\hline \multicolumn{6}{|c|}{ Positive Moment Data (0.4L) } \\
\hline Girder & Strains (in/in) & Girder & Stresses (ksi) & Girder & $\mathbf{d}_{\mathbf{i}}$ values (in) \\
\hline 1 & 0.0006632 & 1 & 18.2540 & 1 & 0.00 \\
2 & 0.0009416 & 2 & 25.1715 & 2 & 0.00 \\
3 & 0.0006632 & 3 & 18.2540 & 3 & 3.00 \\
\hline \multicolumn{8}{|c|}{ Negative Moment Data (1.0L) } \\
\hline Girder & Strains (in/in) & Girder & Stresses (ksi) & Girder & $\mathbf{d}_{\mathbf{i}}$ values (in) \\
\hline 1 & 0.0001004 & 1 & -8.9500 & 1 & 0.00 \\
2 & 0.0001487 & 2 & -13.3380 & 2 & 0.00 \\
3 & 0.0001000 & 3 & -8.9500 & 3 & 2.00 \\
\hline
\end{tabular}

Table 4.2. Mabsout method results showing the element stress, area, distance from neutral axis, and calculated moments for the positive moment region

\begin{tabular}{|c|c|c|c|c|}
\cline { 2 - 5 } \multicolumn{1}{c|}{} & $\begin{array}{c}\text { Stress } \\
\text { (ksi) }\end{array}$ & $\begin{array}{c}\text { Area } \\
\text { (in }^{2}\end{array}$ & $\begin{array}{c}\text { c } \\
\text { (in) }\end{array}$ & $\begin{array}{c}\text { Moment } \\
\text { (in-kips) }\end{array}$ \\
\hline & -1.0314 & 23.05 & -3.862 & 91.82 \\
& -1.0492 & 24.00 & -3.862 & 97.25 \\
Slab & -1.0756 & 24.00 & -3.862 & 99.70 \\
Elements & -1.0984 & 24.00 & -3.862 & 101.81 \\
& -1.1493 & 24.00 & -3.862 & 106.53 \\
& -1.2247 & 23.19 & -3.862 & 109.68 \\
& -1.3166 & 23.19 & -3.862 & 117.90 \\
TF & -1.5204 & 22.50 & -3.862 & 132.12 \\
\hline Elements & -0.7829 & 1.41 & -1.737 & 1.91 \\
& -1.2715 & 1.41 & -1.737 & 3.11 \\
\hline Web & 0.6046 & 1.36 & 1.825 & 1.50 \\
Elements & 6.7068 & 1.36 & 7.262 & 66.21 \\
& 12.5253 & 1.36 & 12.700 & 216.23 \\
& 18.3106 & 1.36 & 18.137 & 451.46 \\
\hline BF & 24.2677 & 1.36 & 23.575 & 777.71 \\
\hline Elements & 27.5948 & 4.50 & 25.857 & 3210.80 \\
& 26.8298 & 4.50 & 25.857 & 3121.80 \\
\hline
\end{tabular}


Table 4.3. Mabsout method results showing the element stress, area, distance from neutral axis, and calculated moments for the positive moment region

\begin{tabular}{|c|c|c|c|c|}
\cline { 2 - 5 } \multicolumn{1}{c|}{} & $\begin{array}{c}\text { Stress } \\
\text { (ksi) }\end{array}$ & $\begin{array}{c}\text { Area } \\
\text { (in }^{2} \text { ) }\end{array}$ & $\begin{array}{c}\text { c } \\
\text { (in) }\end{array}$ & $\begin{array}{c}\text { Moment } \\
\text { (in-kips) }\end{array}$ \\
\hline & 0.1793 & 23.05 & 3.649 & 15.08 \\
& 0.1780 & 24.00 & 3.649 & 15.59 \\
& 0.1795 & 24.00 & 3.649 & 15.72 \\
& 0.1843 & 24.00 & 3.649 & 16.14 \\
& 0.1934 & 24.00 & 3.649 & 16.94 \\
Slab & 0.2080 & 23.19 & 3.649 & 17.60 \\
Elements & 0.2336 & 23.19 & 3.649 & 19.77 \\
& 0.2720 & 22.50 & 3.649 & 22.33 \\
& 0.2264 & 23.19 & 3.649 & 19.16 \\
& 0.1921 & 23.19 & 3.649 & 16.26 \\
& 0.1686 & 24.00 & 3.649 & 14.76 \\
& 0.1501 & 24.00 & 3.649 & 13.15 \\
& 0.1356 & 24.00 & 3.649 & 11.88 \\
Elements & 0.1238 & 24.00 & 3.649 & 10.85 \\
\cline { 2 - 5 } & 0.1143 & 23.05 & 3.649 & 9.62 \\
\cline { 2 - 5 } Web & 0.4998 & 1.41 & 1.524 & 1.07 \\
Elements & 0.5839 & 1.41 & 1.524 & 1.25 \\
\hline BF & -0.4383 & 1.36 & -1.467 & 0.87 \\
& -1.9167 & 1.36 & -6.904 & 17.99 \\
& -3.8663 & 1.36 & -12.342 & 64.87 \\
& -5.4331 & 1.36 & -17.779 & 131.31 \\
& -8.6887 & 1.36 & -23.217 & 274.22 \\
\hline & -10.4254 & 4.50 & -26.070 & 1223.04 \\
& -8.5108 & 4.50 & -26.070 & 998.44 \\
\hline
\end{tabular}

Table 4.4. Results from example distribution factor calculations

\begin{tabular}{|c|c|c|}
\hline Method of Analysis & $\begin{array}{c}\mathbf{0 . 4 L} \\
\text { Position }\end{array}$ & $\begin{array}{c}\mathbf{1 . 0 L} \\
\text { Position }\end{array}$ \\
\hline FHWA Experimental Results & 2.122 & 2.154 \\
\hline Barker Method 1 & 2.384 & 2.562 \\
\hline Barker Method 2 & 2.439 & 2.550 \\
\hline Stallings Method & 2.491 & 2.556 \\
\hline Bakht Method & 2.491 & 2.556 \\
\hline Mabsout Method & 2.100 & 2.308 \\
\hline
\end{tabular}




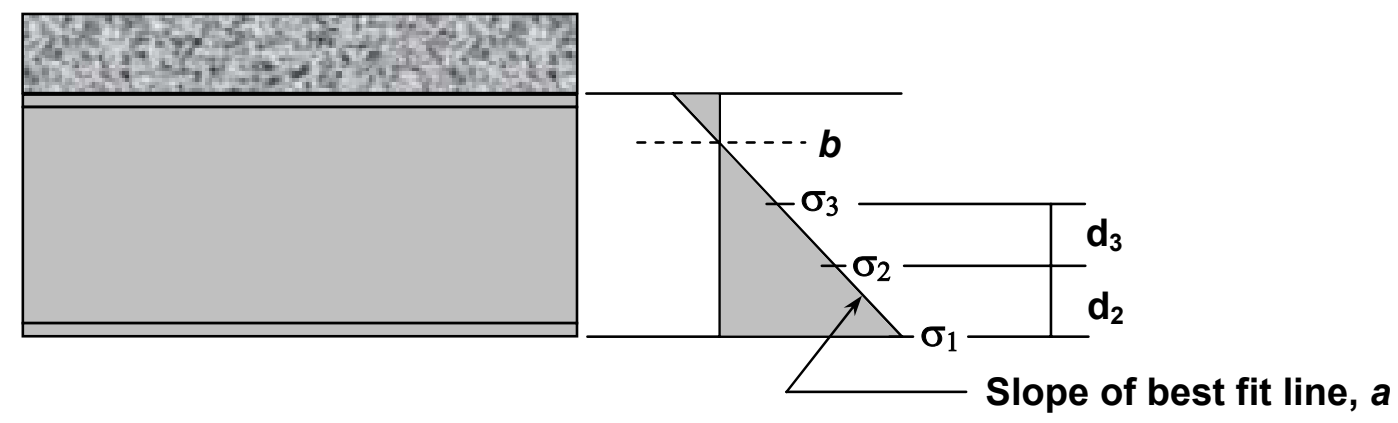

Figure 4.1. Diagram of variables found in Eqn. 4.3 for elastic moment calculation (Barker, 1999)

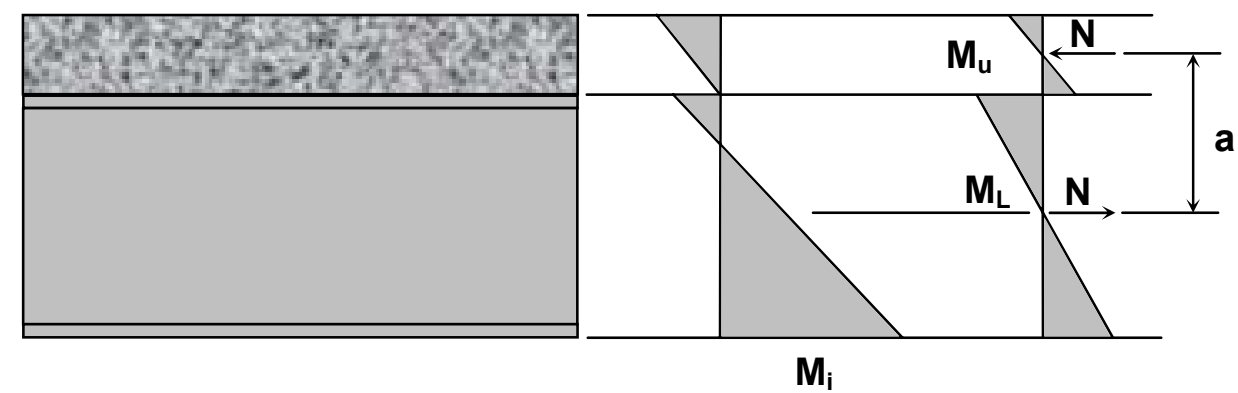

Figure 4.2. Diagram of the componets used to compute elastic moment calculated in Eqns. 4.5 to 4.8 (Barker, 1999) 


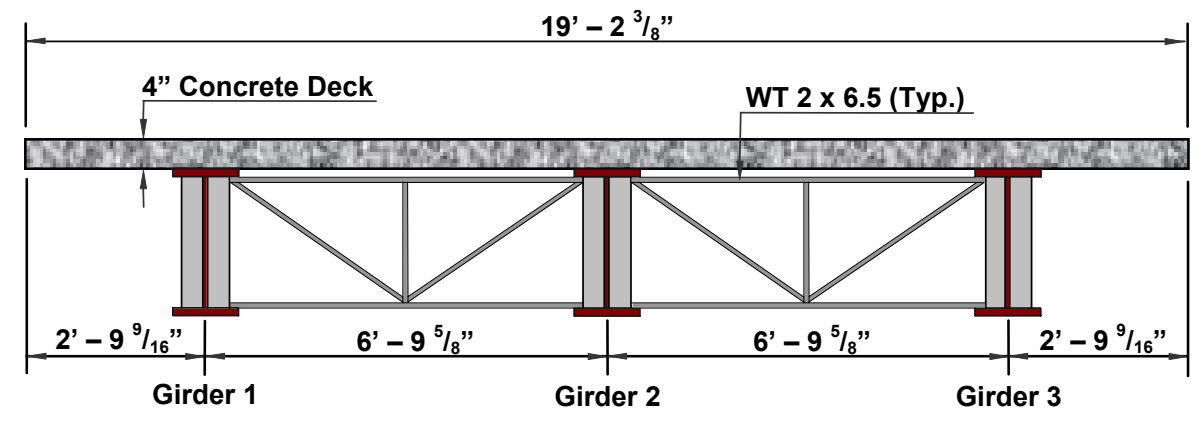

Figure 4.3. AISI- FHWA bridge cross-section

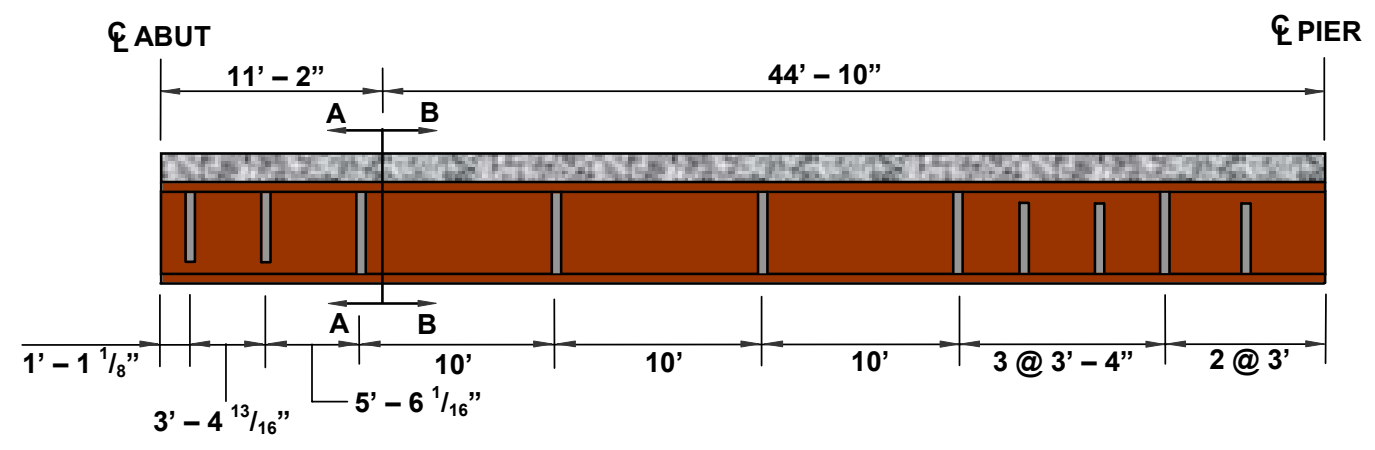

Figure 4.4. AISI-FHWA bridge plan view showing the location of flange transitions 


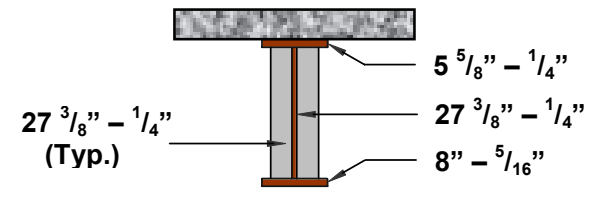

Section A-A

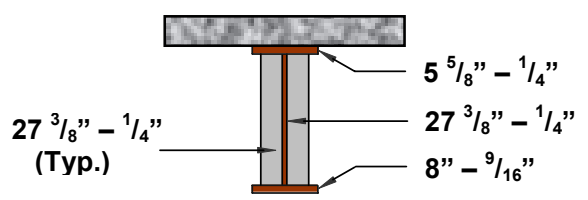

Section B-B

Figure 4.5. Cross section of girder profiles for the AISI-FHWA bridge

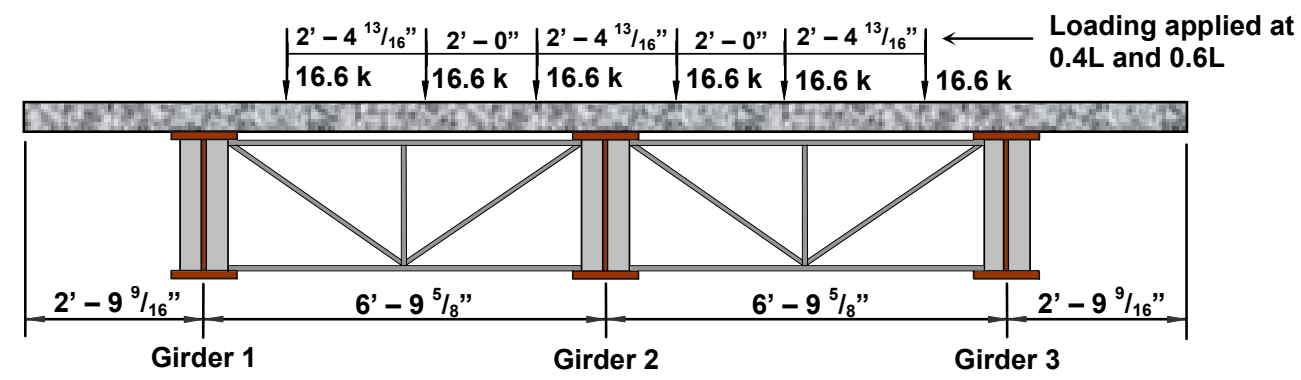

Figure 4.6. Transverse load positions for AISI-FHWA bridge 


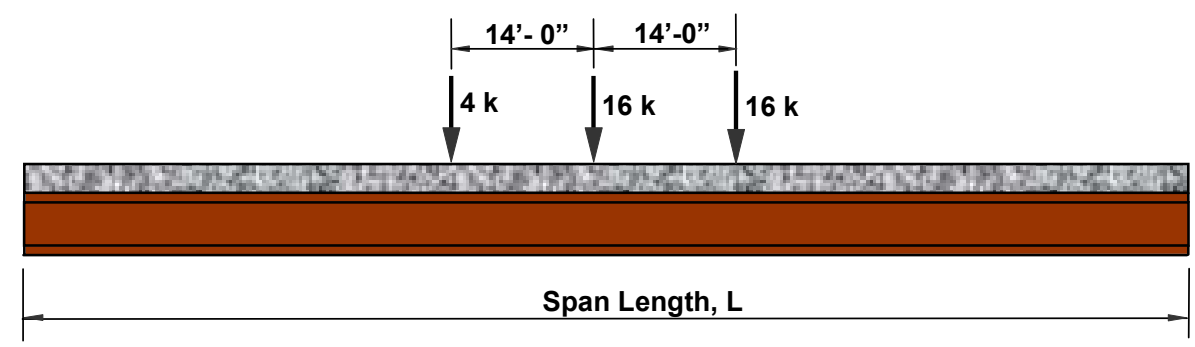

Figure 4.7. Hypothetical loading position of a line of wheels for the calculation of Mabsout $\mathrm{M}^{\text {truck }}$ 


\section{CHAPTER 5}

\section{MODELING OF COMPOSITE STEEL I-GIRDER BRIDGES: DESCRIPTION OF TOOLS AND VERIFICATION STUDIES}

\subsection{Introduction}

The purpose of this chapter is to present a description of the FEA tools used in this study to perform elastic analyses of composite steel bridge superstructures for the purpose of determining live load distribution factors. Also presented in this chapter are several verification studies used in this work to assess the accuracy of the modeling tools employed in this study.

For this purpose, information was obtained through archival literature searches on four previously experimentally tested actual and scale model bridges. The bridges provided in this section represent a wide range of physical size, girder spacing, and span length. Bridges that were selected include a bridge tested by Newmark and Siess (1943), which was one of the test bridges used in the development of the original $\frac{S}{5.5}$

distribution factor. Also included is an AISI-FHWA test bridge subsequently analyzed by Tiedeman et al. (1993) which was used to demonstrate a variety of composite steel bridge performance characteristics including live load distribution. Additionally, there is a medium span length bridge tested by Bakht (1988) that was used to assess live load distribution in the OHBDC (1991) and a bridge tested by Stallings and Yoo (1991). The later was selected due to the completeness of information provided by the investigators and that they used this bridge to assess live load distribution in an actual bridge structure. 


\subsection{Description of FEA modeling tools}

FEA modeling conducted in this study was performed using the commercial programs FEMap (1999), which is both a pre- and post-processor, and ABAQUS v.6.3-1 (2002) which serves as the analysis engine. These tools allow the investigator to construct a refined 3D model of the structure that may individually model girder flange and web plates as well as the reinforced concrete deck. Also, it may incorporate such items as parapets, diaphragms, and cross frame members, and may model the composite action between the reinforced concrete deck and the steel girders. Element selection in these studies include the use of 4-node reduced integration shell elements (ABAQUS S4R) for both the flanges and the web. Mesh discretization of the steel girder consisted of using 2 elements across the width of the flanges and 8 elements through the depth of the web. Steel cross frame members were modeled using a beam element, comprised of 5 elements per cross frame member. The reinforced concrete deck and any secondary stiffening elements, such as edge barriers, were modeled using a 20-node reduced integration solid element (ABAQUS C3D20R). Mesh discretization for the deck slab consisted of using approximately 1 element per square $\mathrm{ft}$. The composite action between the steel girders and the slab was modeled using a multi point constraint (ABAQUS MPC Beam) spaced longitudinally approximately every foot. Figure 5.1 shows a typical FEA mesh for one of the bridges in this study. As all analyses were performed well within the elastic range fro the bridges, typical elastic constitutive laws for both the steel and concrete were selected to represent the material response. For the parametric studies described in Chapter 6, all steel was assumed to be $50 \mathrm{ksi}$ and the concrete was assumed 
to be $4 \mathrm{ksi}$. Whereas, for the bridges modeled in this chapter, material properties reported by the specific investigators were incorporated in the respective models.

\subsection{Verification Studies}

\subsubsection{Comparison with Newmark Bridges}

Newmark and Siess (1943) preformed extensive research on a laboratory bridge to assess load distribution and to calibrate the distribution factor used in the current AASHTO Standard Specification. In their research reports, Newmark and Siess (1943), they present both the experimentally determined deflections and live load distribution factors for several loading conditions.

The bridge was simply supported and had a span length of 15 feet. The crosssection consists of a 1.75 in. thick deck supported by 5 girders spaced at $1 \mathrm{ft}$. -6 in., as shown in Fig. 5.2. Figure 5.3 shows an elevation of the bridge. Also shown in Figs. 5.1 and 5.2 is the loading used to assess deflections and live load distribution. The loading consisted of placing four 5-kip concentrated loads symmetrically about the centerline of the girder at $1 \mathrm{ft} .-6$ in. on center.

Deflections were evaluated based on the information given by Newmark and Siess (1943) from the field testing results and compared to the FEA modeled bridge created for this study. The results are presented graphically in Fig. 5.4 which shows the deflection obtained on the bottom flange of each girder at the location of the load. A 
summary of comparisons reveals only a $2.6 \%$ to $5.6 \%$ difference in deflection between the Newmark values and the WVU FEA.

Distribution factors were also evaluated from the data obtained from the FEA model and information provided by Newmark and Siess. Table 5.1 shows the distribution factors computed using the methods described in Chapter 4 for this particular bridge along with the experimental value calculated by Newmark and Siess and the AASHTO LRFD distribution factor. While the differences between the Barker procedures, Stallings procedure, and Bakht's procedure are approximately $22 \%$ lower than the experimental values and the value calculated using Mabsout's method is approximately $14 \%$ higher, due to the scale of the bridge it is felt that the values are well within reason and, coupled with subsequent comparisons, yield an acceptable level of accuracy for these methods. While there is only a $2 \%$ difference between the experimental distribution factor and that computed using the AASHTO LRFD equation, the geometry of this bridge fell well outside the range of applicability of the AASHTO LRFD equations and therefore no reasonable conclusions can be made as to the accuracy of this comparison.

\subsubsection{Comparison with FHWA-AISI Model Bridge}

In 1990, the Federal Highway Administration (FWHA) and the American Iron and Steel Institute (AISI) performed an extensive testing program on a two-span continuous plate girder bridge to assess a variety of steel bridge performance characteristics. Research done by Tiedeman et al. (1993) compared FEA model results 
with actual bottom-flange stresses obtained in the testing of the FHWA-AISI Bridge. The research done in this report provides an opportunity to effectively compare stress values obtained using various FEA packages along with the experimentally obtained values.

A description of the superstructure geometry for the AISI-FWHA test bridge is provided in Section 4.6. Figures 4.1 through 4.3 show the cross section and elevation views presenting the dimensions for all members of the superstructure along with girder profiles for the respective girder transitions for this bridge. The loading cases evaluated by Tiedeman et al. (1993) consisted of simulated wheel loads being placed at the $0.44 \mathrm{~L}$ point and the $0.65 \mathrm{~L}$ point. These were done to maximize the negative and positive bending respectively. Points $0.44 \mathrm{~L}$ and $0.66 \mathrm{~L}$ were used as opposed to the theoretical points of $0.4 \mathrm{~L}$ and $0.6 \mathrm{~L}$ due to constraints with the physical loading apparatus. Loading for this set of tests consisted of applying a series of 7 kip concentrated loads spaced $2 \mathrm{ft}$.$4 \frac{13}{16}$ in. apart via hydraulic actuators that were attached to the floor and pull a high tensile rod through the deck. The load pattern and transverse placement of loads is identical to the pattern used in the 16.6 kip wheel load tests conducted on this structure, described in 4.6 and shown in Fig. 4.4 for the maximum positive and negative bending locations. For both one lane and three lanes loaded, Tiedeman et al. measured the bottom flange stresses at the $0.4 \mathrm{~L}$ and 5 feet in front of the $1.0 \mathrm{~L}$ at the $0.4 \mathrm{~L}$ and $1.0 \mathrm{~L}$ point and compared these values with the results of their FEA. Tiedeman et al. used the ANSYS finite element program developed by Swanson Analysis System, Inc. to conduct their FEA modeling. 
Figures 5.5 and 5.6 show the comparisons for the bottom flange stresses measured at the longitudinal points in Girder 2 between the experimental results, Tiedeman et al.'s FEA, and the WVU FEA for the one and three lane loaded cases respectively. Figures 5.7 and 5.8 show similar results for the $0.65 \mathrm{~L}$ load cases also with one and three lanes loaded respectively. It can be seen that there is excellent agreement between the Tiedeman et al. and WVU FEA as well as between both analytical models and the experimental data.

\subsubsection{Comparison with Bakht Medium Span Length Bridge}

Bakht (1988) performed extensive research on the development of live load distribution factors for the Ontario Highway Bridge Design Code (1991), and the computation of design factors, $D_{d f}$ where Distribution Factor $=\frac{S}{D_{d f}}$, used in the development of the live load distribution factor equation currently used in the OHBDC. Bakht performed experimental testing of a medium span length simply supported bridge to experimentally determine the $D_{d f}$ value and compare this with predictions in the OHBDC as well as to evaluate other design parameters. In this study, an analytical comparison is made with the experimentally determined deflections and $D_{d f}$ values for this bridge.

The simply supported bridge had a span length of 150 feet and consisted of an 8 in. deck placed on 5 girders spaced at $9.75 \mathrm{ft}$. with a $7.75 \mathrm{in}$. sidewalk and a $24 \mathrm{in}$. high parapet as shown in Fig. 5.9. Figure 5.10 shows the plan view of the Bakht Bridge giving the cross-frame dimensions ( $\mathrm{L} 4 \times 3 \times 0.375)$ location along the span every 25 feet with the 
location of flange transitions designated by A-A and B-B. The girder cross-sections can be seen in Fig. 5.11 and consist of a 16 in. $x 1$ in. top flange plate and an 18 in. $x 1.5$ in. bottom flange plate for section A-A while section B-B has a top flange plate of 18 in. $\mathrm{x}$ 1.25 in. and a bottom flange plate of 20 in. x 1.75 in., the web plate for both sections A-A and B-B is an 84 in. $x 0.375$ in. Three loading conditions are used in this testing involving a Kenworth and a Mack truck with the longitudinal loading positions and values shown in Fig. 5.12 and the horizontal loading positions shown in Fig. 5.13. It is important to note that load case 1 and load case 2 are loaded in the same position except the values of axle loads are different.

The design factor, $D_{d f}$, was evaluated using the method described by Bakht (1988) from Eqn. 4.12 (given on page 68) by multiplying the factor of girder spacing divided by number of wheel lines applied during the loading with the factor of the sum of the bottom flange strains divided by the bottom flange strain of the girder of interest. The calculated distance factors for each load case and the distance factor determined by Bakht given in Table 5.2. To summarize, the Load Case 1 distance factor showed a $7.2 \%$ higher difference from the Bakht distance factor, the Load Case $2 D_{d f}$ was $4.1 \%$ higher than the Bakht distance factor, and the Load Case 3 distance factor was $0.4 \%$ lower than the Bakht distance factor. The FEA results represent a very good correlation with the Bakht's values, showing Bakht's method of computing distribution factors to work successfully coupled with the analytical modeling used in these studies.

The FEA deflections were also compared with Bakht's recorded deflections. The deflection for the three load cases can be seen graphically on Fig. 5.14. These results well match trends observed in grillage modeling conducted by Bakht to assess bending 
moments. Bakht (1988) explains the difference between the analytical and experimental results as attributable to bearing restraint.

\subsubsection{Comparison with Stallings Bridges}

Stallings and Yoo (1991) field-tested several bridges to compare ratings determined from FEA grid analyses to AASHTO computed ratings. Comprehensive bridge geometry, loading, and experimental results were presented by Stallings and Yoo for the Childersburg bridge. For this reason, this bridge was selected as a calibration tool for the FEA modeling as well as to compare the various methods for computing the distribution factors described in Chapter 4.

The bridge modeled in this study consisted of two simply supported approach spans for a steel truss with span lengths of 44 feet and 77 feet with a 6.75 in. deck placed on 4 girders spaced at 5.83 feet with a 10.5 in. sidewalk on each side of the deck as seen in Fig. 5.15. The steel girders were Bethlehem B beams taken from the 1930 Bethlehem steel manual with the cross-section of the girder profile for each bridge shown in Fig. 5.16. Two lanes of trucks were placed at the transverse loading position shown in Fig. 5.15 and the longitudinal placement shown in Fig. 5.17. Note that Fig. 5.17 also shows the weight of each wheel.

The load distribution factors for the two Stallings Bridges using the procedures described in Chapter 4 were computed and are presented in Table 5.3 along with the distribution factor obtained by Stallings and Yoo in the experimental testing. A summary

of the results again provide very good correlation with the Barker, Bakht, and Stalling 
procedures producing a reasonable difference between the analytical values and the distribution factors acquired from physical testing. The Mabsout procedure showed a larger difference with the largest error being approximately $16 \%$ conservative.

\subsection{Conclusions}

This chapter successfully compared FEA models with previous experimental tests, experimentally determined distribution factors providing an evaluation of the different distribution factor methods described in Chapter 4, and compared with previous FEA results. The Newmark and AISI-FHWA Bridges helped in the verification of proper modeling techniques and provided some additional information to use in the selection of a proper procedure for the calculation of load distribution factors to be used in further studies. Also Newmark Bridge showed excellent accuracy in the modeling of deflections and also the stress comparisons from the AISI-FHWA Bridge were accurately modeled and compared well with previous FEA studies of that bridge.

Further parametric studies, described in Chapter 6, require the accurate calculation of distribution factors. Therefore, it is important to select an accurate and robust method to calculate these factors from the FEA data. The Mabsout method requires the selection of a hypothetical effective section that may influence the results. The other methods described in this study all produce distribution factors that are very close to one another. Bakht's distribution factor method has been extensively correlated with the results of field test data and was used as the basis for the formulation of the live 
load distribution factors in the OHBDC. For this reason, further parametric studies in this work will use the Bakht procedure to compare the live load distribution factor. 
Table 5.1. Example distribution factors for Newmark bridge

\begin{tabular}{|c|c|c|c|c|c|c|c|c|}
\hline Bridge & $\begin{array}{c}\text { Exp. } \\
\text { Results }\end{array}$ & $\begin{array}{c}\text { Barker } \\
\# 1\end{array}$ & $\begin{array}{c}\text { Barker } \\
\mathbf{\# 2}\end{array}$ & Stallings & Bakht & Mabsout & $\begin{array}{c}\text { AASHTO } \\
\text { LRFD }\end{array}$ & $\begin{array}{c}\text { AASHTO } \\
\text { Standard }\end{array}$ \\
\hline Newmark & 0.587 & 0.461 & 0.456 & 0.456 & 0.456 & 0.671 & 0.6 & 0.273 \\
\hline
\end{tabular}

Table 5.2. Design factors for Bakht medium span bridges

\begin{tabular}{|c|c|c|}
\hline Load Case & $\begin{array}{c}\text { Bakht Design } \\
\text { Factor (ft) }\end{array}$ & $\begin{array}{c}\text { FEA Design } \\
\text { Factor (ft) }\end{array}$ \\
\hline \hline Load Case 1 & 12.70 & 11.84 \\
\hline Load Case 2 & 12.34 & 11.84 \\
\hline Load Case 3 & 7.55 & 7.51 \\
\hline
\end{tabular}


Table 5.3. Distribution factors for Stallings's bridges

\begin{tabular}{|c|c|c|c|c|c|c|c|c|}
\hline Bridge & $\begin{array}{c}\text { Experimental } \\
\text { Results }\end{array}$ & $\begin{array}{c}\text { Barker } \\
\mathbf{\# 1}\end{array}$ & $\begin{array}{c}\text { Barker } \\
\mathbf{\# 2}\end{array}$ & Stallings & Bakht & Mabsout & $\begin{array}{c}\text { AASHTO } \\
\text { LRFD }\end{array}$ & $\begin{array}{c}\text { AASHTO } \\
\text { Standard }\end{array}$ \\
\hline Stallings $\mathbf{- 4 4}$ & 1.190 & 1.078 & 1.075 & 1.072 & 1.072 & 1.029 & 1.130 & 1.060 \\
\hline Stallings $\mathbf{- 7 7}$ & 1.100 & 1.065 & 1.061 & 1.058 & 1.058 & 1.036 & 1.086 & 1.060 \\
\hline
\end{tabular}




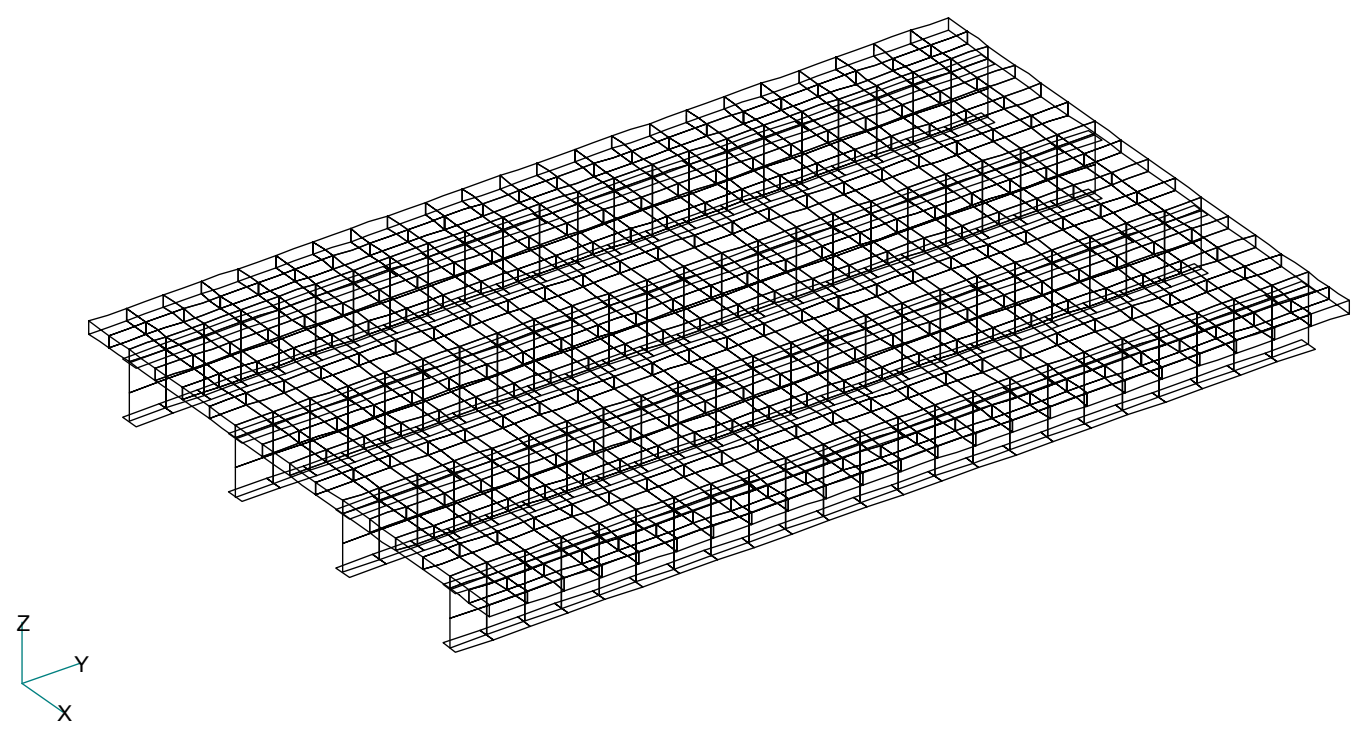

Figure 5.1. Typical FEA mesh discretization for WVU bridge model

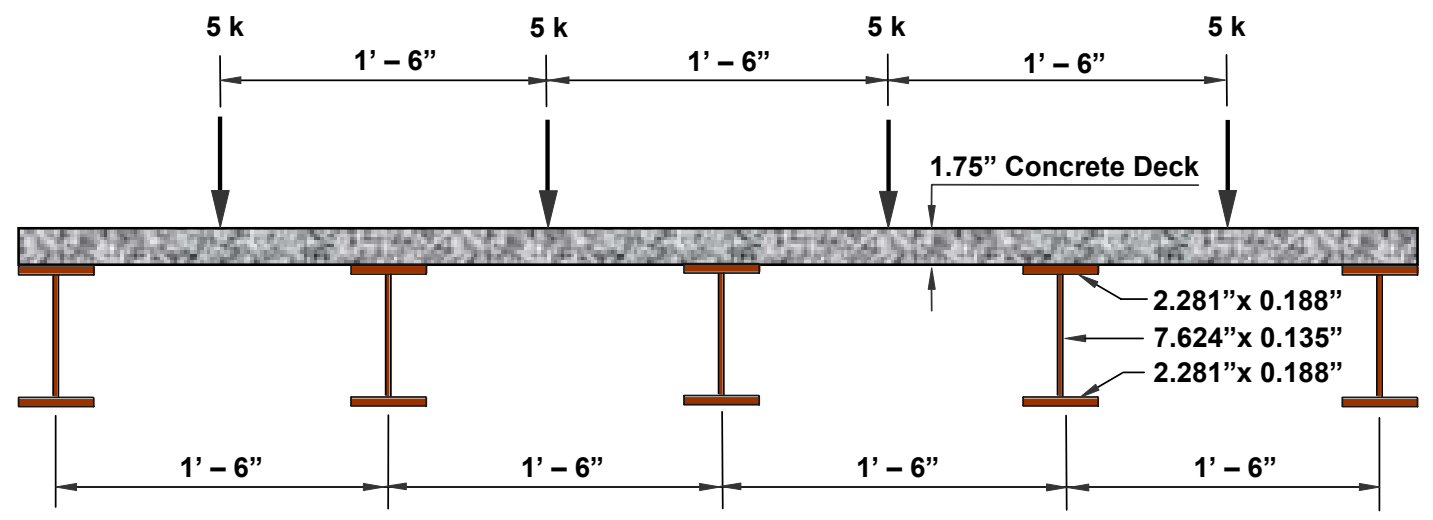

Figure 5.2. Newmark bridge cross-section with horizontal loading positions 


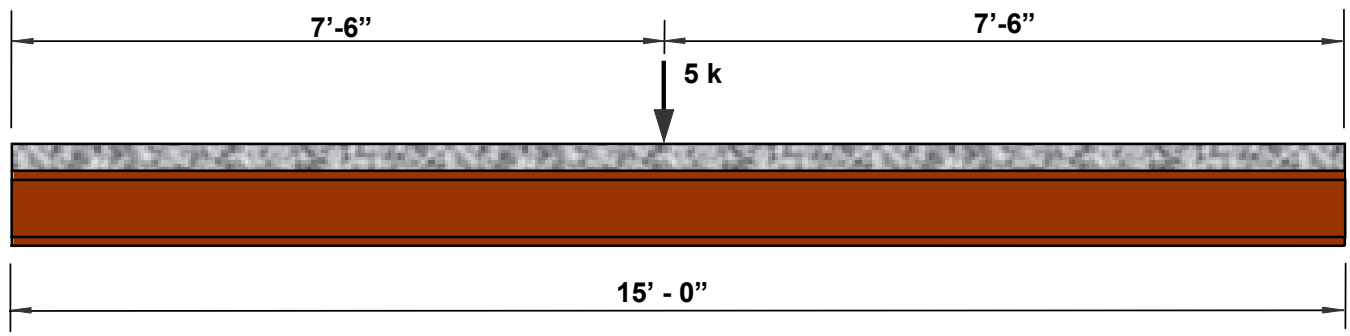

Figure 5.3. Plan view of the Newmark bridge showing longitudinal dimensions and loading

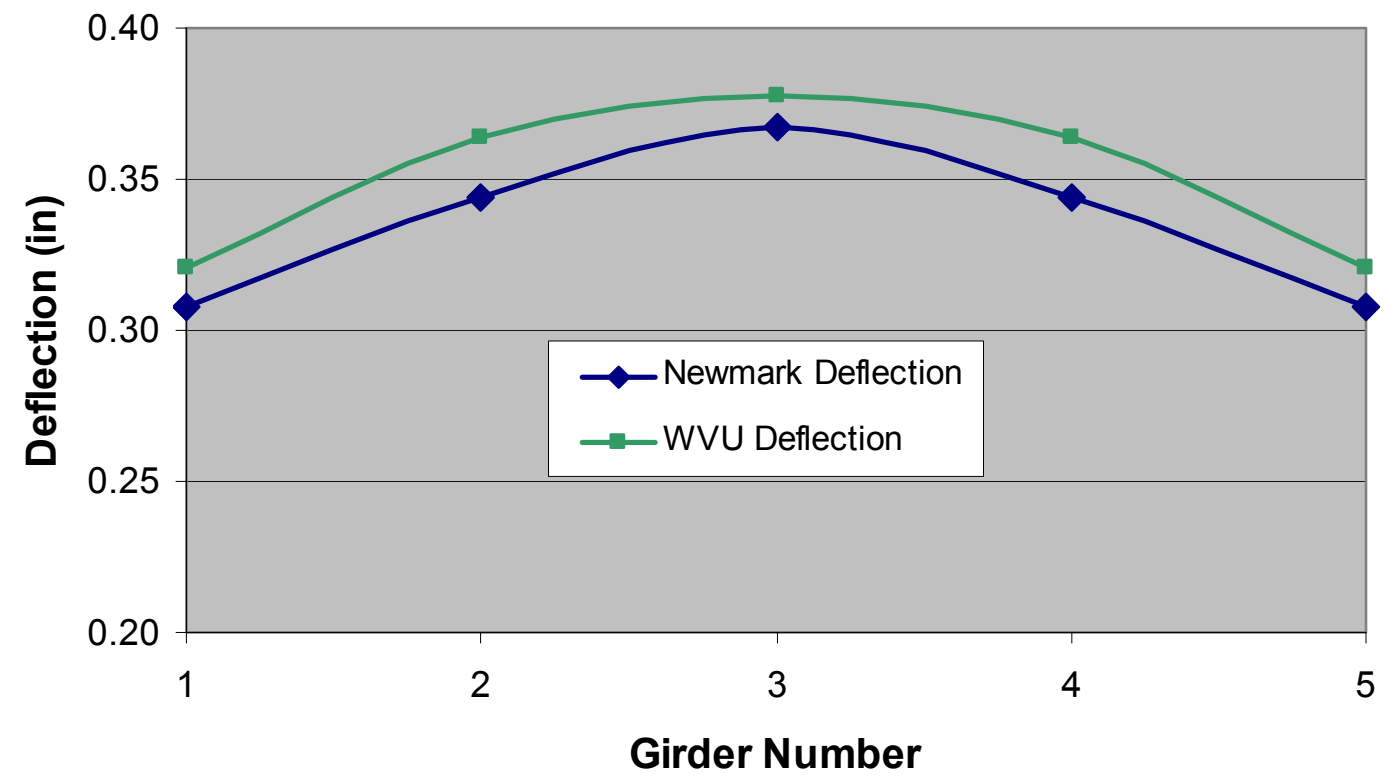

Figure 5.4. Comparison of deflection between Newmark experimental testing and WVU FEA for the Newmark bridge in Section 5.2.1 


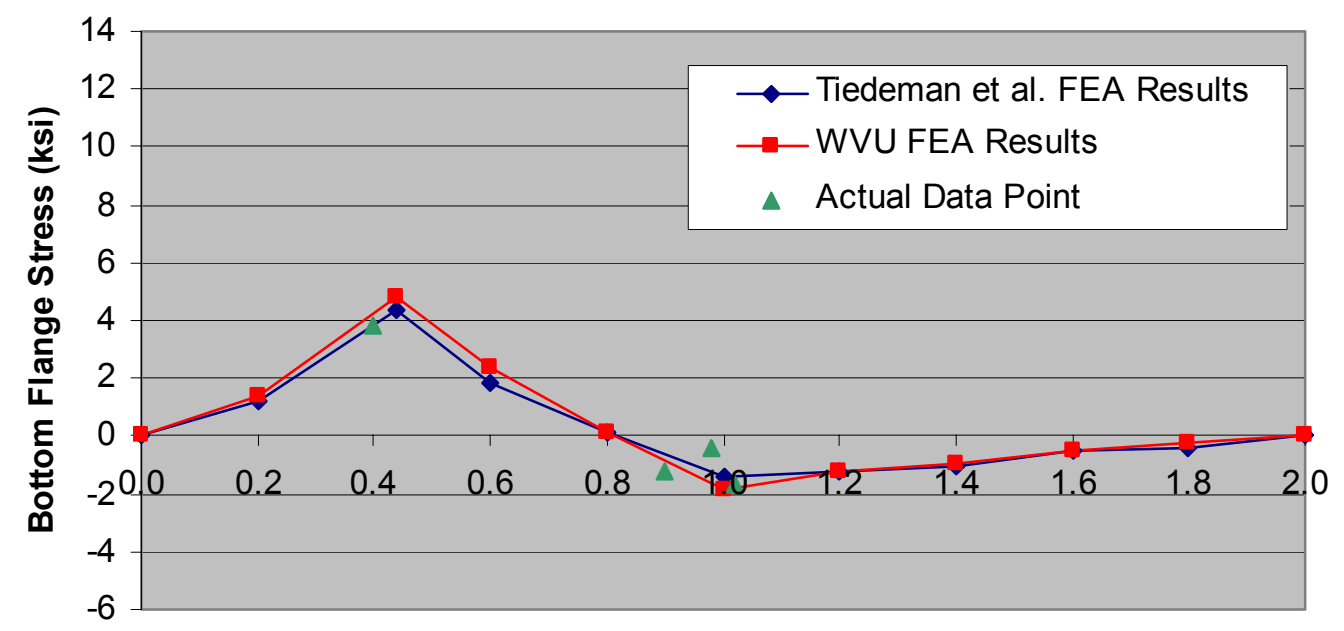

Distance along Spans

Figure 5.5. Bottom flange stress for $0.44 \mathrm{~L}-1$ lane-loaded comparing actual data, Tiedeman et al. FEA results, and WVU FEA results

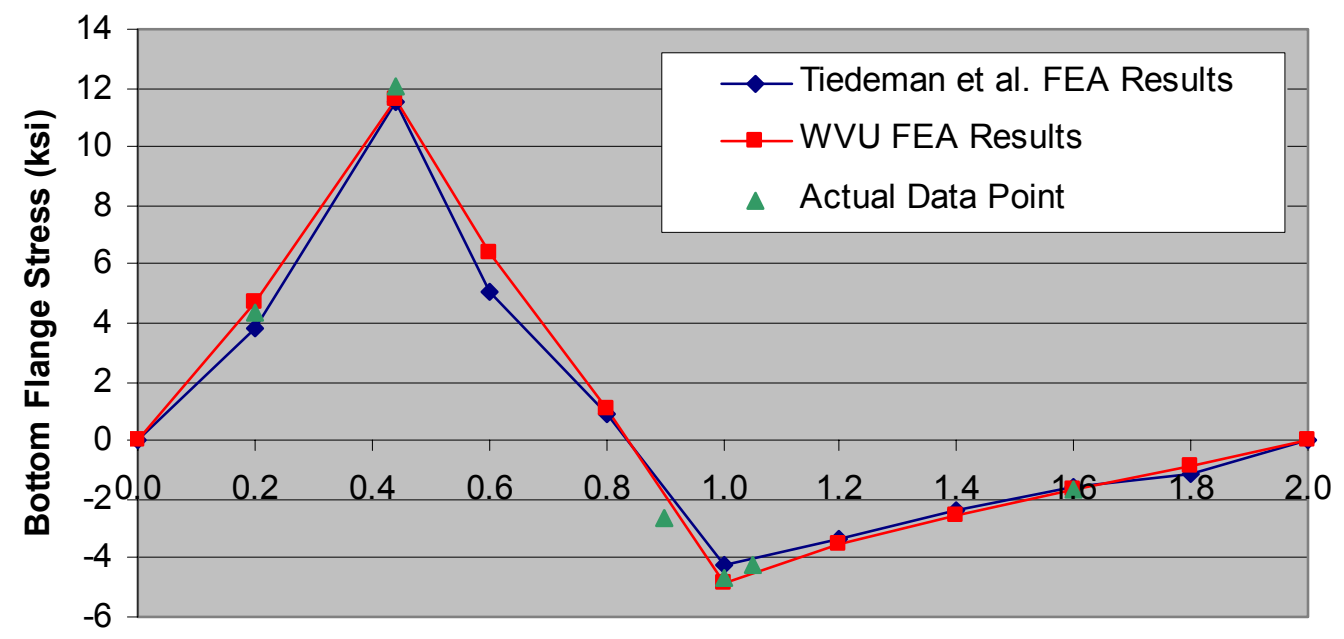

Distance along Spans

Figure 5.6. Bottom flange stress for $0.44 \mathrm{~L}-3$ lanes-loaded comparing actual data, Tiedeman et al. FEA results, and WVU FEA results 


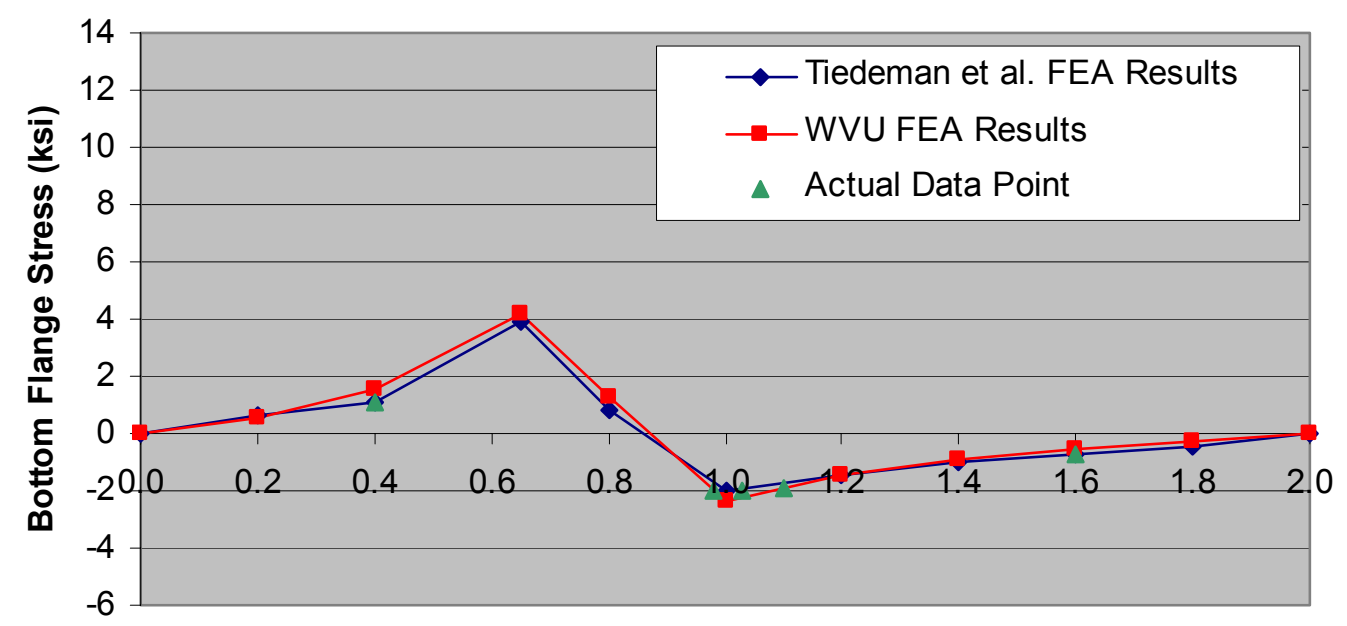

Distance along Spans

Figure 5.7. Bottom flange stress for $0.65 \mathrm{~L}-1$ lane-loaded comparing actual data, Tiedeman et al. FEA results, and WVU FEA results

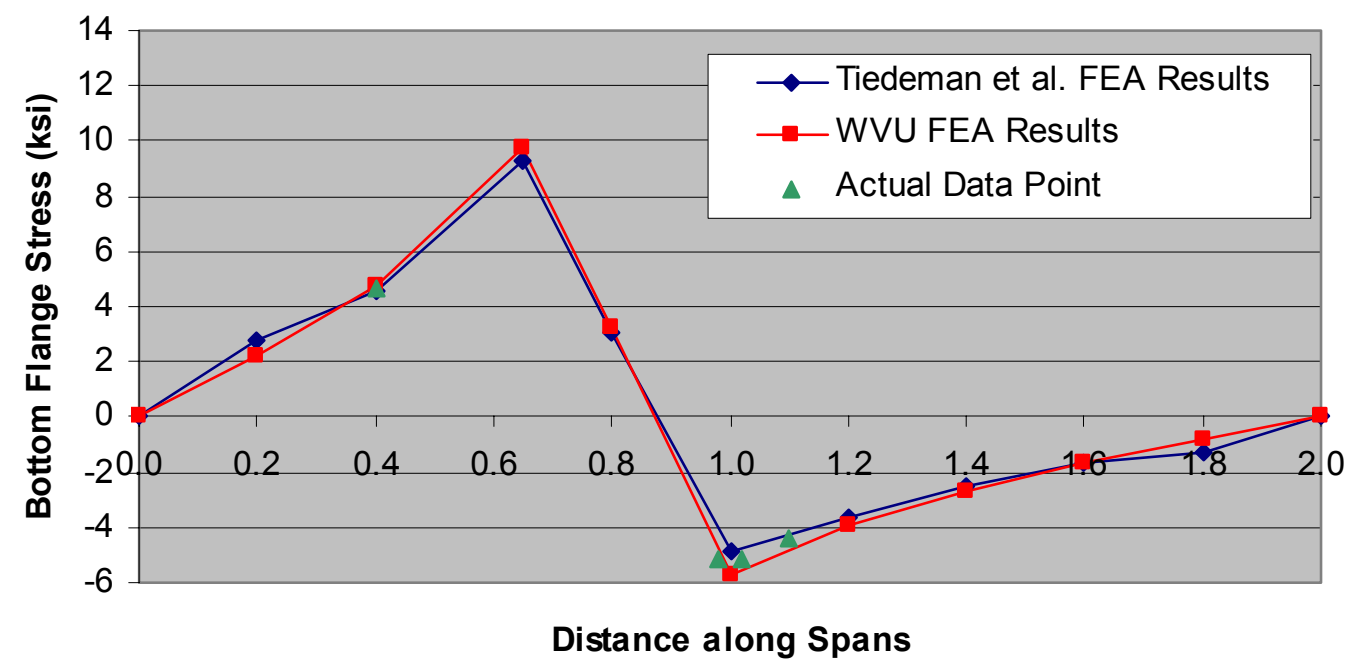

Figure 5.8. Bottom flange stress for $0.65 \mathrm{~L}-3$ lanes-loaded comparing actual data, Tiedeman et al. FEA results, and WVU FEA results 


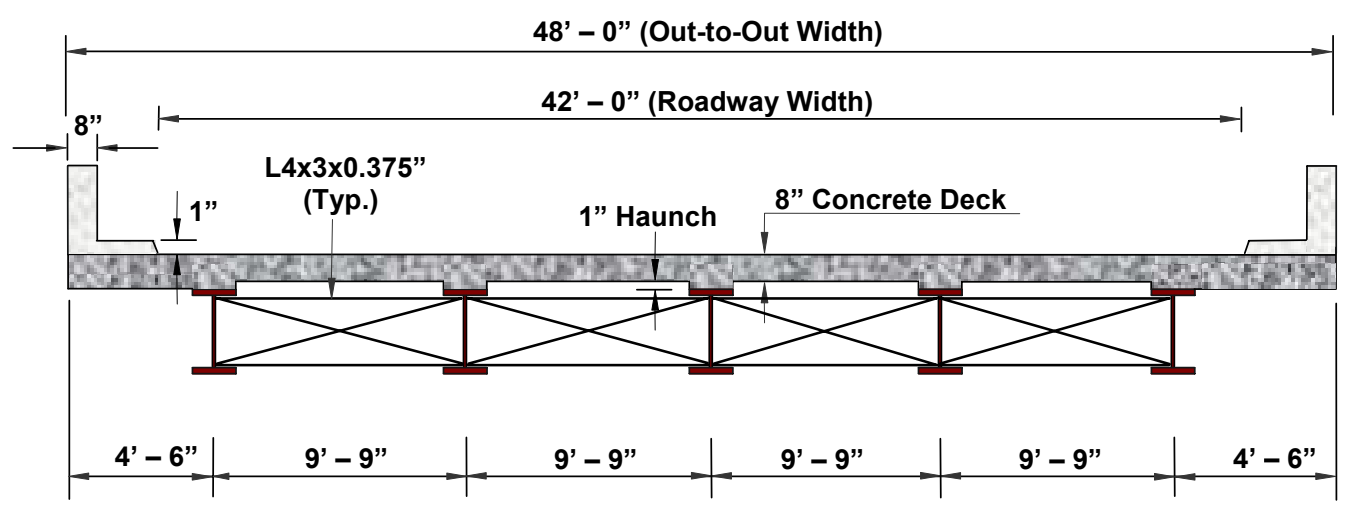

Figure 5.9. Cross-section view dimensions of Bakht medium span length bridge
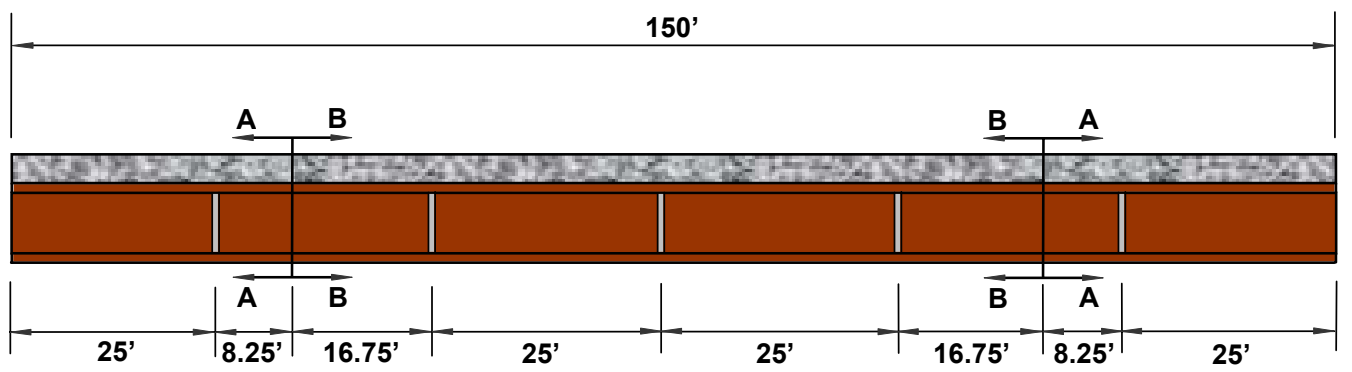

Figure 5.10. Plan view of Bakht bridge showing girder transitions and cross-frame locations 


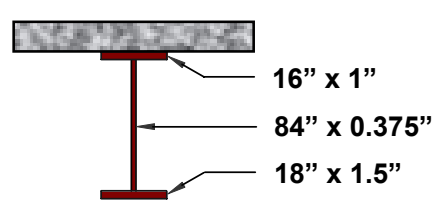

Section A-A

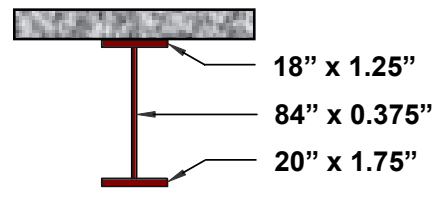

Section B-B

Figure 5.11. Cross-sections for Bakht medium span length bridge

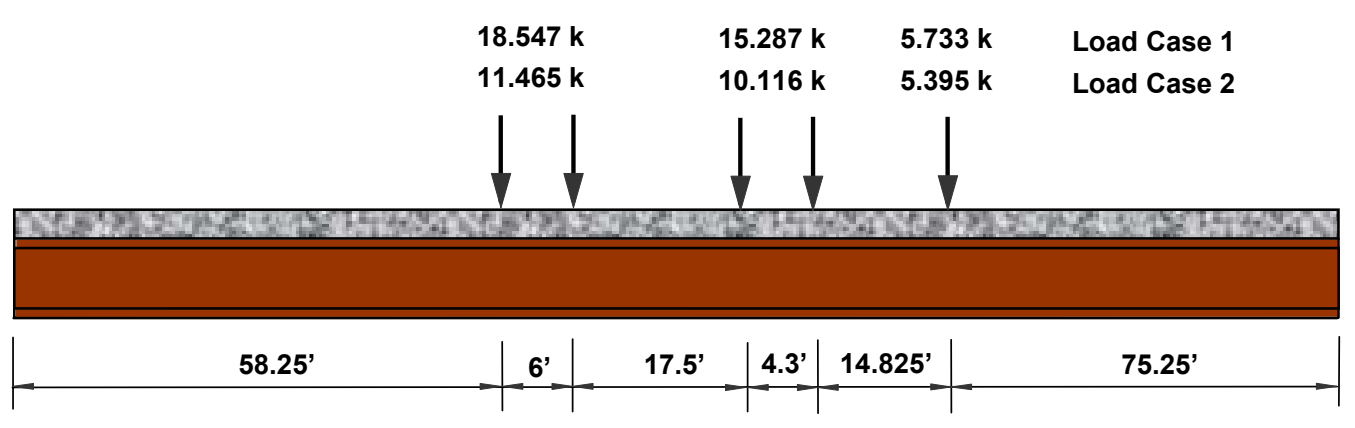

(a) Details of Kenworth Truck

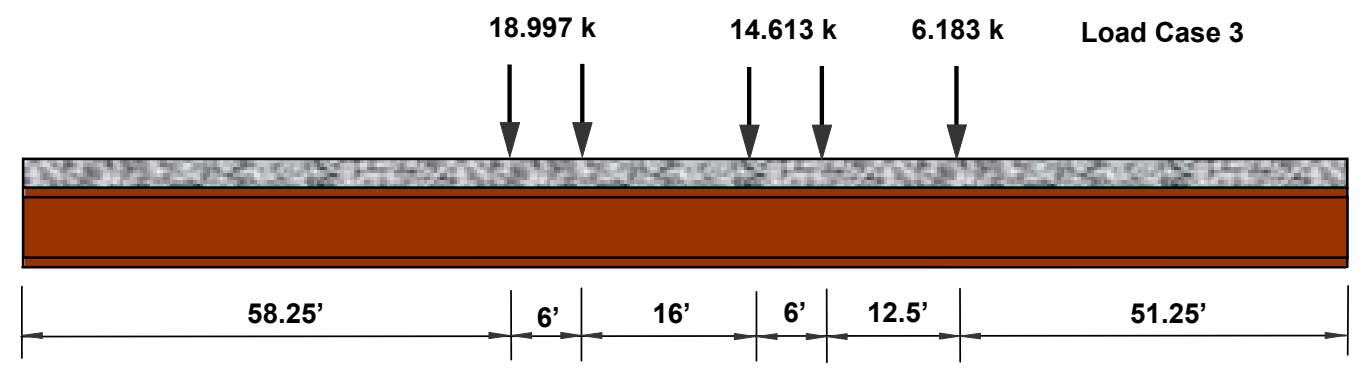

(b) Details of Mack Truck

Figure 5.12. Plan view showing the location of longitudinal loading for each load case involving (a) Kenworth truck and (b) Mack truck 

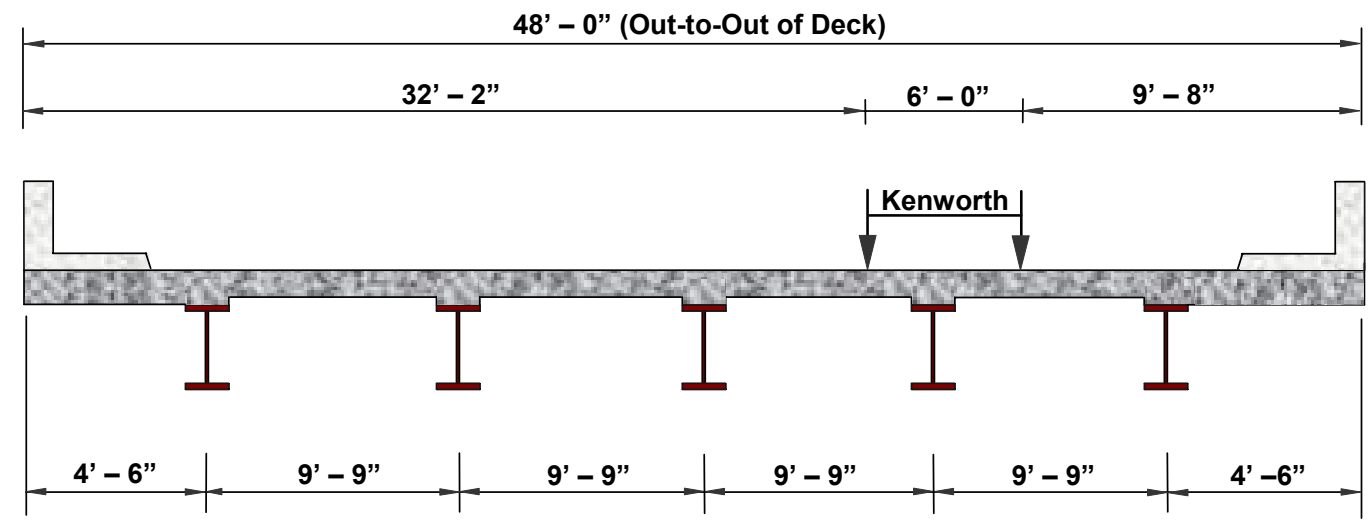

Load Case 1 and 2
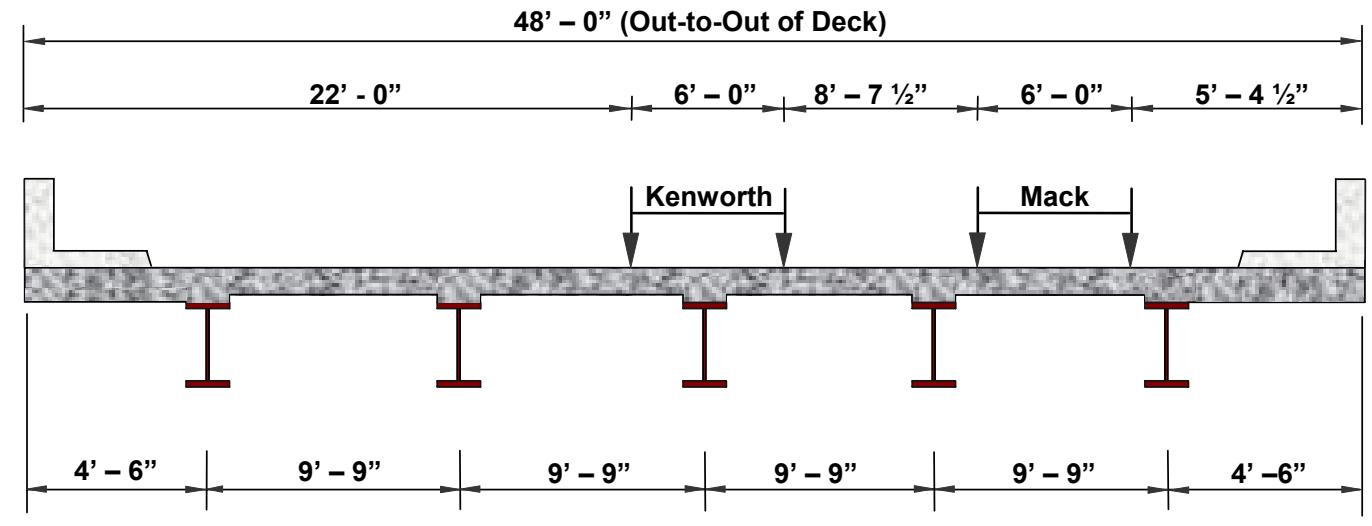

Load Case 3

Figure 5.13. Plan view showing the location of transverse loading positions for each load case involving a (a) Kenworth and (b) Mack truck 


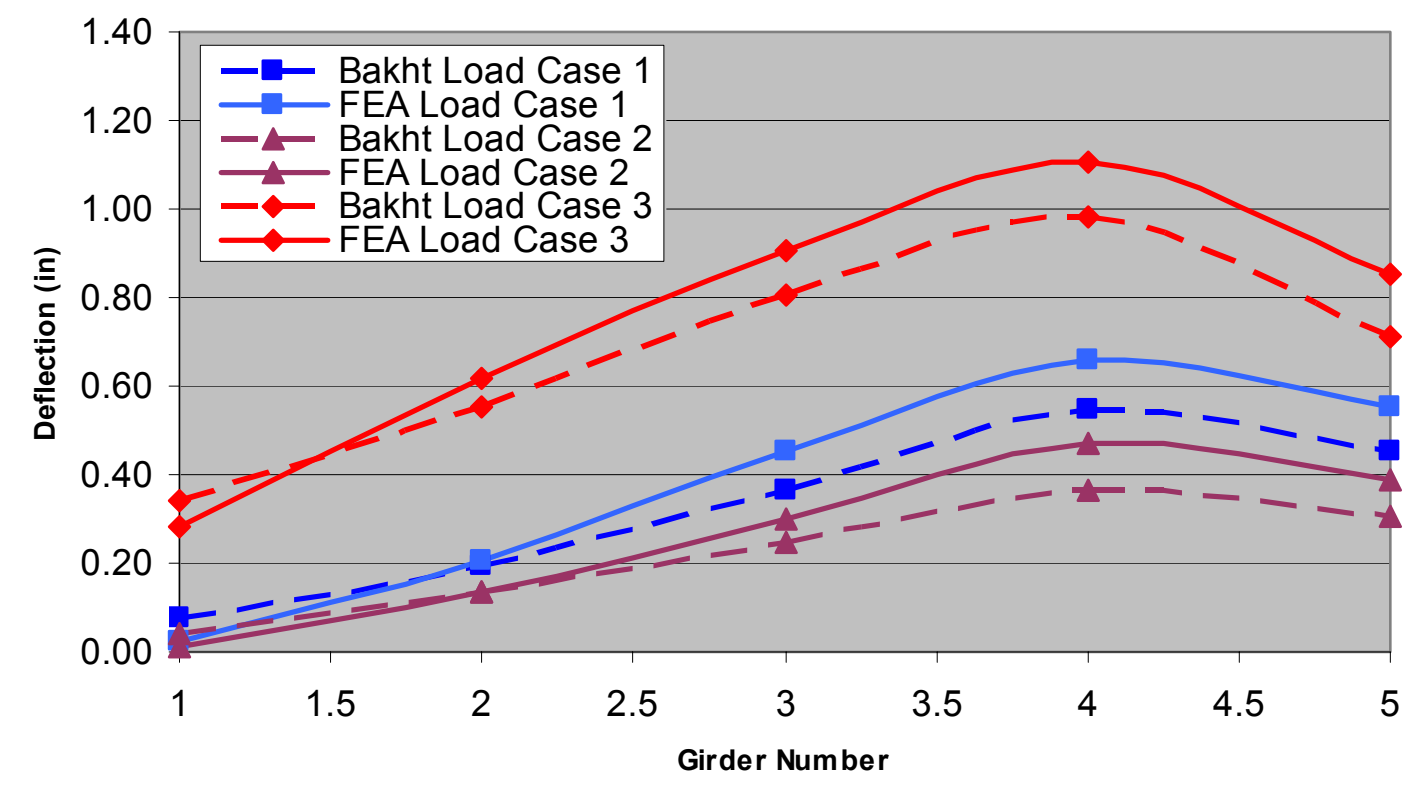

Figure 5.14. Comparison of deflection from the Bakht field-testing and WVU FEA model for the 3 load cases presented in Section 5.2.3

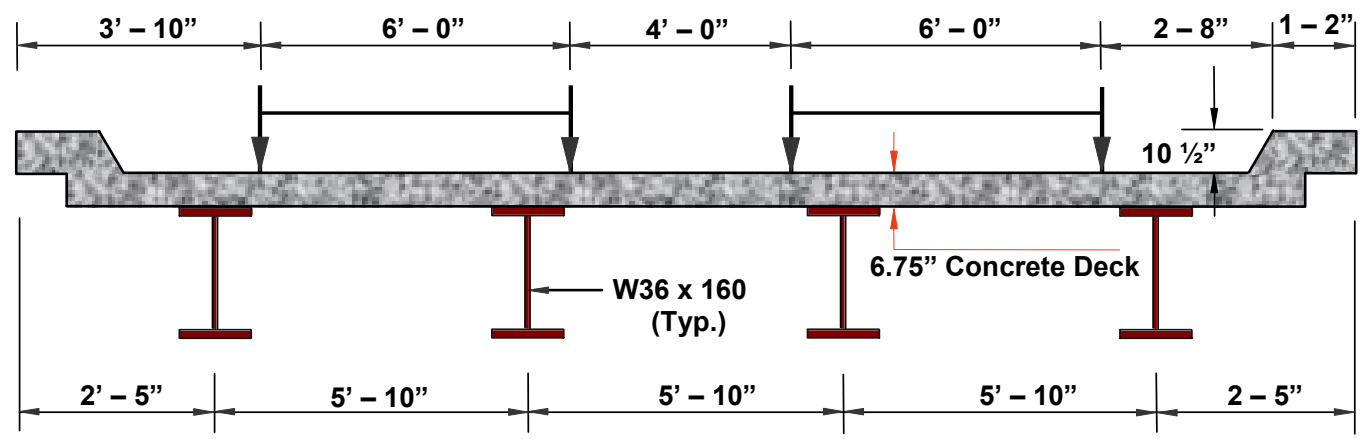

Figure 5.15. Stalling bridges cross-section and horizontal truck loading positions 


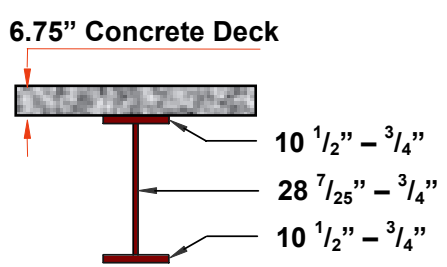

$44 \mathrm{ft}$ Bridge

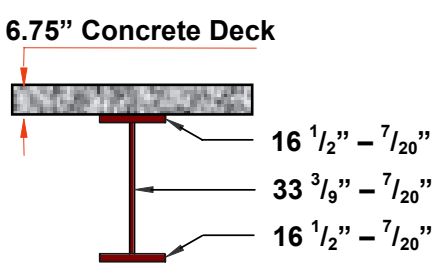

77 ft Bridge

Figure 5.16. Cross-section for Stallings's bridges

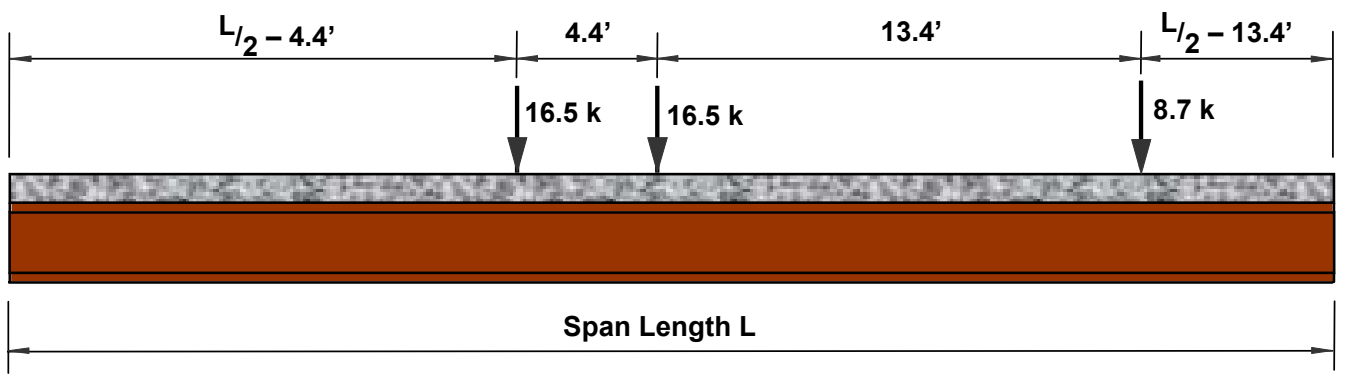

Figure 5.17. Plan view of Stalling bridges showing longitudinal dimensions and loading for two truck tests 


\section{CHAPTER 6}

\section{PARAMETRIC STUDIES}

\subsection{Introduction}

The primary objective of this chapter is to develop a set of parametric studies for a discrete range of parameters for simply supported composite steel bridge superstructures to evaluate live load distribution in these structures. The goal is to use the analysis results to compute the live load distribution factors using Bakht's procedure (described in Section 4.4). The resulting distribution factors will subsequently be assessed to ascertain the relative importance of parameters selected in the study, they will be compared with current AASHTO Specifications, and a simplified model applicable to the range of parameters used in this study will be proposed. Results of the sensitivity studies, along with the development of the proposed distribution factor model will be presented subsequently in Chapter 7.

\subsection{Range of Parameters}

Three 4-girder cross sections with varying girder spacings were selected for the parametric studies. These sections, shown in Figs. 6.1, 6.2, and 6.3, and labeled crosssection 1, cross-section 2, and cross-section 3 respectively, are representative of typical bridges in the U.S. inventory. The primary parameters in this study include girder spacing, girder span length, steel yield strength, and cross section span-to-depth ratio. 
- Girder spacing: As shown in Figs. 6.1, 6.2, and 6.3, three girder spacings were incorporated in these studies: $11 \mathrm{ft}$. -6 in. (a relative wide girder spacing), $10 \mathrm{ft}$. 4 in. (an intermediate spacing), and $8 \mathrm{ft}$. -6 in. (a narrow girder spacing)

- Girder span length: All bridge models were simply supported and have span lengths ranging from $100 \mathrm{ft}$. to $300 \mathrm{ft}$. Cross-sections one and three had lengths of 100, 200, and $300 \mathrm{ft}$. whereas cross section 2 had span lengths of 100, 150, 200 , and $250 \mathrm{ft}$.

- Steel yield strength: For each given variation of girder spacing, span length, and span to depth ratio cross section geometries were provided for both homogenous Gr. $50(\mathrm{Fy}=50 \mathrm{ksi})$ design and Gr. $70(\mathrm{Fy}=70 \mathrm{ksi})$ design.

- Span-to-depth ratio: Three span to depth ratios were used, $\mathrm{L} / \mathrm{D}=20,25$, and 30 where $\mathrm{D}=$ overall superstructure depth .

The bridge cross sections used in this study were initially taken from those incorporated in the AISI Short Span Steel Bridges (1995). Previous work with these cross sections (Clingenpeel, 2001; Barth et al., 2001) was conducted to assess optimized designs for these members. Commercial software based on AASHTO Standard Specifications (Simon v8.1, 1996) and the AASHTO LRFD Specifications (MDX, 1999) was used to perform line girder designs to produce least weight members for the range of parameters described above. These optimized sections served as the basis for the $3 \mathrm{D}$ FEA models conducted in this study. Table 6.1 presents the basic cross section geometry for each girder used in this work. Also Fig. 6.4 provides a hypothetical girder elevation as a reference to the parameters provided in Table 6.1. 
For each hypothetical configuration a FEA model of the superstructure was constructed and two lanes of HS20 truck loading were placed to maximize the positive bending at $0.5 \mathrm{~L}$ of one of the interior girders in the bridge. The transverse loading positions are also presented in Figs. 6.1, 6.2, and 6.3. Figure 6.5 shows the longitudinal load position used to maximize mid-span bending. After an elastic analysis was performed for the given loading, bottom flange stain data was used in conjunction with the Bakht procedure (described in Section 4.4) to compute the live load distribution factors.

Figure 6.6 shows the variation in girder stiffness as a function of span length for the bridges in the parametric study. This figure also plots stiffness versus span length for the bridges used in the NCHRP parametric study conducted to derive the AASHTO LRFD distribution factors, for a population of bridges in various state DOT inventories (discussed in Section 3.4.1), and for a small group of actual bridges from an inventory at WVU. In this figure stiffness is defined as the term, $K_{g}$ (see AASHTO section 4.6.2.2.1) where

$$
K_{g}=n \cdot\left(I+A e^{2}\right)
$$

It is interesting to note that the range of stiffness values incorporated in the NCHRP parametric studies falls well outside the feasible stiffness values of actual bridges. This fact is, however, noted by the NCHRP investigators. Also of note is the fact that it is the inclusion of this stiffness parameter, $K_{g}$, in the distribution factor equation (see Eqn. 6.1 and AASHTO section 4.6.2.2.1) that leads to part of the deterrent to the use of the LRFD equations. 


\subsection{General Results}

As previously stated, after performing each analysis, the mid-span bottom flange stresses were substituted in the expression

$$
D_{d f}=\left(\frac{S}{n}\right) \cdot\left(\frac{\sum \varepsilon_{i}}{\varepsilon_{\max }}\right)
$$

to determine the design factor, $D_{d f}$. Given the calculated $D_{d f}$ value, the live load distribution factor for mid-span moment was then computed as

$$
\text { Distance Factor }=\frac{S}{D_{d f}}
$$

Table 6.2 provides a summary of the resulting $D_{d f}$ values and corresponding distribution factors for each of the parametric variations. Also shown in this table are the respective distribution factors computed using the AASHTO LRFD (AASHTO, 2002) and AASHTO Standard Specifications (AASHTO, 1992) along with the percent difference between these values and the analytical distribution factor. The average percent difference between the AASHTO LRFD Specifications and the FEA results is $20 \%$ on the conservative side. Also the corresponding maximum and minimum percent difference is $33 \%$ and $8 \%$ respectively. For the AASHTO Standard Specifications, the average difference between the FEA results and the code predictions is $29 \%$ on the conservative side and the corresponding maximum and minimum values are $46 \%$ and $15 \%$ respectively. 


\subsubsection{Influence of girder spacing}

Figure 6.7 shows the influence of girder spacing on the analytical $D_{d f}$ values from each of the three cross section girder spacings. It can be seen, as would be expected, that there is a fairly increasing linear relationship between girder and the $D_{d f}$ value. This is exactly the trend witnessed by Newmark and Siess and incorporated in the AASHTO Standard Specifications.

\subsubsection{Girder span length}

Figure 6.8 shows the influence of span length on the design factor, $D_{d f}$, for each of the three cross sections. It can be seen that for each respective cross section, there is a small increase in the $D_{d f}$ values as a function of increased span length.

\subsubsection{Steel yield strength}

A comparison between yield strength may be made by assessing the results shown in Table 6.2. For example, in cross section 1 bridge 1L2S115F5LD20 is a $200 \mathrm{ft}$. span length bridge with $\mathrm{L} / \mathrm{D}=20$ comprised of $50 \mathrm{ksi}$ steel. The resulting distribution factor for this bridge was 0.606 . The corresponding $70 \mathrm{ksi}$ bridge 1L2S115F7LD20, yielded a distribution factor of 0.602 . The difference between these value being $0.66 \%$. This trend is similar for other yield stress comparisons with the average difference being $0.5 \%$. It should however be expected that for the bridges assessed in this parametric study there 
would be negligible difference in load distribution as a function of yield stress. For each respective member, the yield stress is changed while the $\mathrm{L} / \mathrm{D}$ value is kept approximately the same. Therefore, these members will have similar stiffness values.

\subsubsection{Span to depth ratio}

For a typically proportioned bridge, the span to depth ratio has a direct relationship with the girder stiffness. Figure 6.9 shows a plot of the resulting analytical $D_{d f}$ values as a function of stiffness, as defined by $K g$, for each of the load cross sections. While for very low stiffness values there is a small variation in the trend, over the wide range of stiffness values used in this study there is a very negligible change in the resulting $D_{d f}$ value.

\subsection{Further Data Reduction}

The results of the parametric studies coupled with sensitivity analyses presented in this chapter will subsequently be used in Chapter 7 to develop a simplified empirically based model for the distribution factor. This model will be used to predict maximum positive bending in simply supported spans within the range of parameters evaluated in this study. 
Table 6.1. Key parameters for WVU parametric bridges

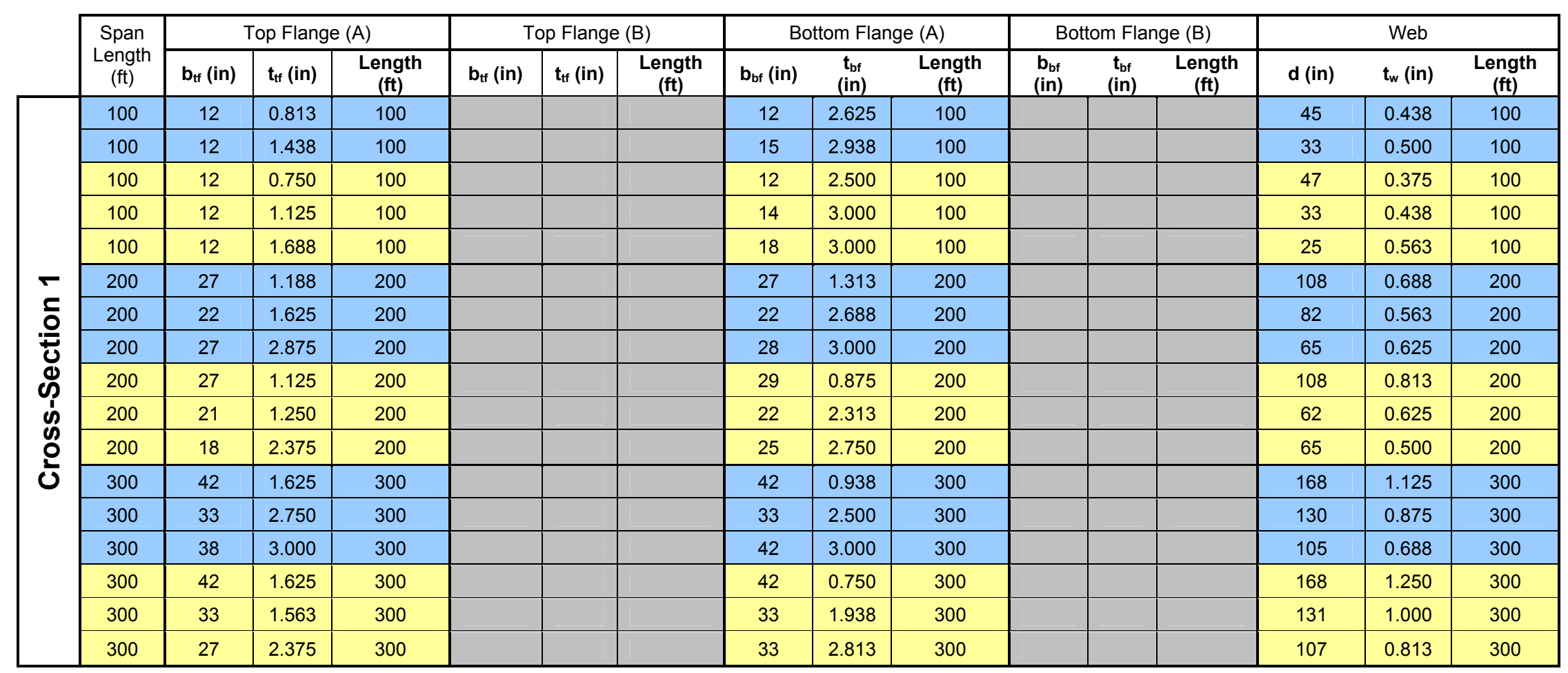


Table 6.1. cont'd

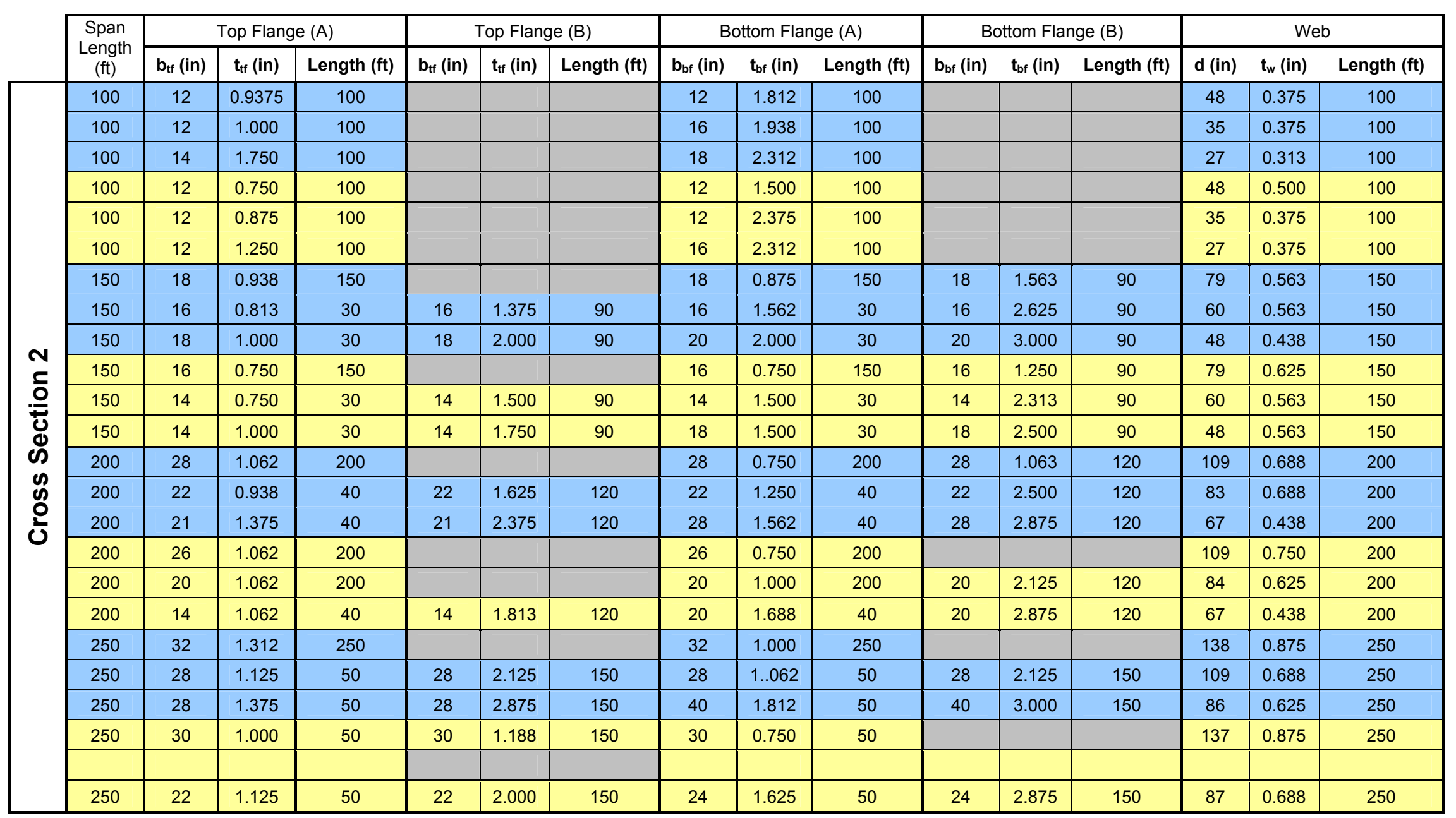


Table 6.1. cont'd

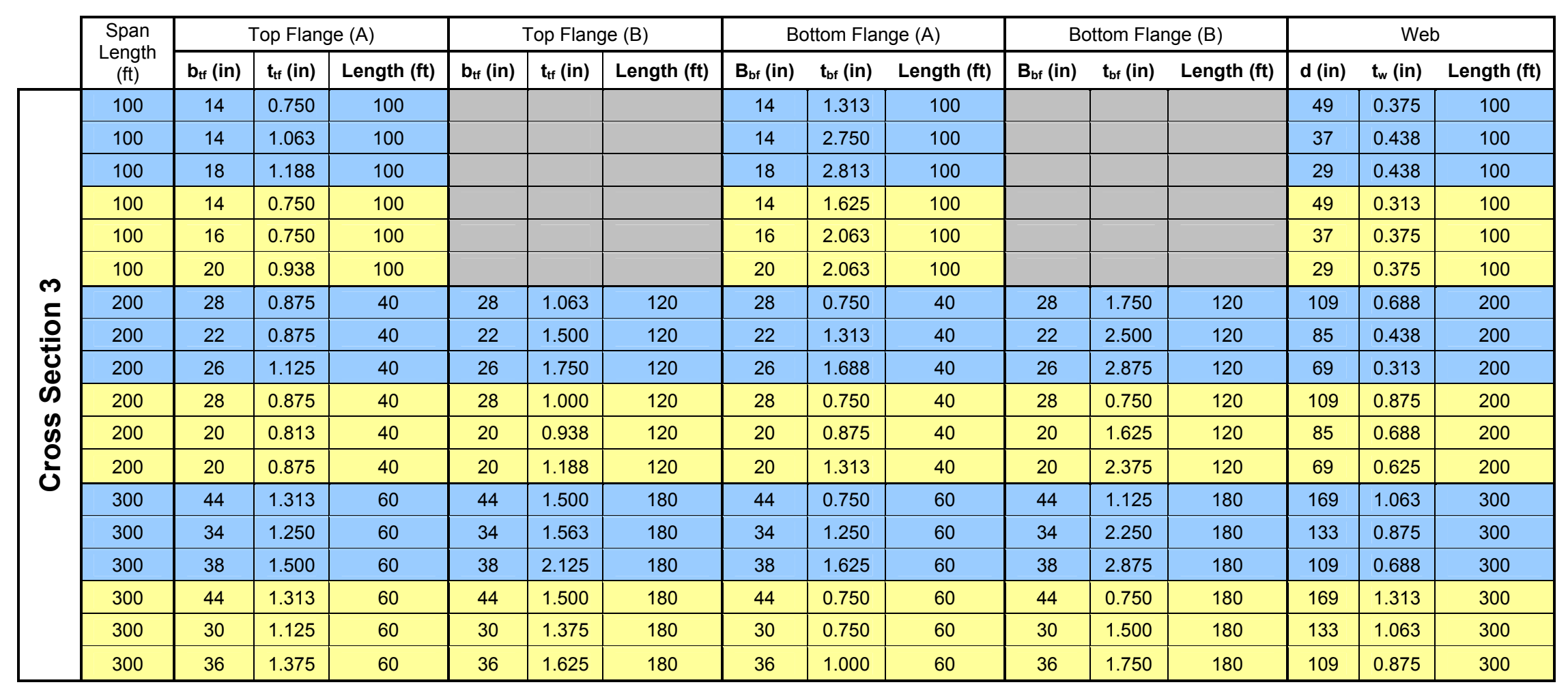


Table 6.2. Summary of FEA results for distribution factors calculated from WVU parametric study

\begin{tabular}{|c|c|c|c|c|c|c|c|}
\hline & Bridge & $\underset{D_{\text {df }}}{\text { FEA Design Factor, }}$ & $\begin{array}{c}\text { Resulting FEA } \\
\text { DF }\end{array}$ & $\begin{array}{c}\text { AASHTO LRFD } \\
\text { DF }\end{array}$ & 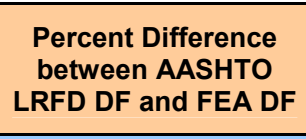 & $\begin{array}{c}\text { AASHTO } \\
\text { Standard DF }\end{array}$ & $\begin{array}{c}\text { Percent Difference } \\
\text { between AASHTO } \\
\text { Standard DF and } \\
\text { FEA DF }\end{array}$ \\
\hline \multirow{17}{*}{ 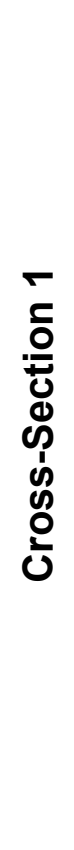 } & 1L1S115F5LD20 & 17.628 & 0.652 & 0.787 & 21 & 0.864 & 33 \\
\hline & 1L1S115F5LD25 & 17.844 & 0.644 & 0.772 & 20 & 0.864 & 34 \\
\hline & 1L1S115F7LD20 & 17.764 & 0.647 & 0.788 & 22 & 0.864 & 34 \\
\hline & 1L1S115F7LD25 & 17.816 & 0.645 & 0.767 & 19 & 0.864 & 34 \\
\hline & 1L1S115F7LD30 & 17.968 & 0.640 & 0.755 & 18 & 0.864 & 35 \\
\hline & 1L2S115F5LD20 & 18.962 & 0.606 & 0.785 & 30 & 0.864 & 43 \\
\hline & 1L2S115F5LD25 & 18.990 & 0.606 & 0.765 & 26 & 0.864 & 43 \\
\hline & 1L2S115F5LD30 & 19.210 & 0.599 & 0.758 & 27 & 0.864 & 44 \\
\hline & 1L2S115F7LD20 & 19.088 & 0.602 & 0.778 & 29 & 0.864 & 44 \\
\hline & 1L2S115F7LD25 & 19.104 & 0.602 & 0.720 & 20 & 0.864 & 44 \\
\hline & 1L2S115F7LD30 & 19.164 & 0.600 & 0.743 & 24 & 0.864 & 44 \\
\hline & 1L3S115F5LD20 & 19.026 & 0.604 & 0.797 & 32 & 0.864 & 43 \\
\hline & 1L3S115F5LD25 & 19.370 & 0.594 & 0.775 & 30 & 0.864 & 45 \\
\hline & 1L3S115F5LD30 & 19.388 & 0.593 & 0.763 & 29 & 0.864 & 46 \\
\hline & 1L3S115F7LD20 & 19.158 & 0.600 & 0.796 & 33 & 0.864 & 44 \\
\hline & 1L3S115F7LD25 & 19.394 & 0.593 & 0.767 & 29 & 0.864 & 46 \\
\hline & 1L3S115F7LD30 & 19.434 & 0.592 & 0.750 & 27 & 0.864 & 46 \\
\hline
\end{tabular}


Table 6.2. cont'd

\begin{tabular}{|c|c|c|c|c|c|c|c|}
\hline & Bridge & $\begin{array}{c}\text { FEA Design Factor, } \\
D_{\mathrm{df}}\end{array}$ & FEA DF & $\begin{array}{c}\text { AASHTO LRFD } \\
\text { DF }\end{array}$ & $\begin{array}{l}\text { Percent Difference } \\
\text { between AASHTO } \\
\text { LRFD DF and FEA DF }\end{array}$ & $\begin{array}{c}\text { AASHTO } \\
\text { Standard DF }\end{array}$ & $\begin{array}{c}\text { Percent Difference } \\
\text { between AASHTO } \\
\text { Standard DF and } \\
\text { FEA DF } \\
\end{array}$ \\
\hline \multirow{23}{*}{ 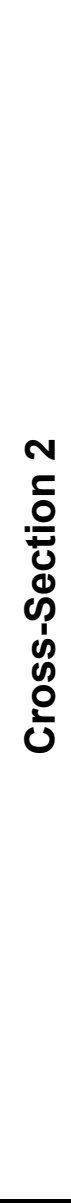 } & 1L1S104F5LD20 & 16.402 & 0.630 & 0.747 & 19 & 0.727 & 15 \\
\hline & 1L1S104F5LD25 & 16.424 & 0.629 & 0.727 & 16 & 0.727 & 16 \\
\hline & 1L1S104F5LD30 & 16.324 & 0.633 & 0.718 & 13 & 0.727 & 15 \\
\hline & 1L1S104F7LD20 & 16.394 & 0.630 & 0.742 & 18 & 0.727 & 15 \\
\hline & 1L1S104F7LD25 & 16.392 & 0.630 & 0.722 & 15 & 0.727 & 15 \\
\hline & 1L1S104F7LD30 & 16.504 & 0.626 & 0.709 & 13 & 0.727 & 16 \\
\hline & 1L15S104F5LD20 & 17.210 & 0.600 & 0.744 & 24 & 0.727 & 21 \\
\hline & 1L15S104F5LD25 & 17.244 & 0.599 & 0.726 & 21 & 0.727 & 21 \\
\hline & 1L15S104F5LD30 & 17.348 & 0.596 & 0.715 & 20 & 0.727 & 22 \\
\hline & 1L15S104F7LD20 & 17.306 & 0.597 & 0.743 & 24 & 0.727 & 22 \\
\hline & 1L15S104F7LD25 & 17.342 & 0.596 & 0.723 & 21 & 0.727 & 22 \\
\hline & 1L15S104F7LD30 & 17.444 & 0.592 & 0.711 & 20 & 0.727 & 23 \\
\hline & 1L2S104F5LD20 & 17.480 & 0.591 & 0.746 & 26 & 0.727 & 23 \\
\hline & 1L2S104F5LD25 & 17.440 & 0.592 & 0.726 & 23 & 0.727 & 23 \\
\hline & 1L2S104F5LD30 & 17.458 & 0.592 & 0.709 & 20 & 0.727 & 23 \\
\hline & 1L2S104F7LD20 & 17.566 & 0.588 & 0.744 & 27 & 0.727 & 24 \\
\hline & 1L2S104F7LD25 & 17.560 & 0.588 & 0.723 & 23 & 0.727 & 24 \\
\hline & 1L2S104F7LD30 & 17.494 & 0.591 & 0.704 & 19 & 0.727 & 23 \\
\hline & 1L25S104F5LD20 & 17.474 & 0.591 & 0.772 & 31 & 0.727 & 23 \\
\hline & 1L25S104F5LD25 & 17.378 & 0.595 & 0.731 & 23 & 0.727 & 22 \\
\hline & 1L25S104F5LD30 & 17.304 & 0.597 & 0.720 & 21 & 0.727 & 22 \\
\hline & 1L25S104F7LD20 & 17.528 & 0.590 & 0.748 & 27 & 0.727 & 23 \\
\hline & 1L25S104F7LD30 & 17.386 & 0.594 & 0.715 & 20 & 0.727 & 22 \\
\hline
\end{tabular}


Table 6.2. cont'd

\begin{tabular}{|c|c|c|c|c|c|c|c|}
\hline & Bridge & $\begin{array}{l}\text { FEA Design Factor, } \\
\mathrm{D}_{\mathrm{df}}\end{array}$ & FEA DF & $\begin{array}{c}\text { AASHTO LRFD } \\
\text { DF }\end{array}$ & $\begin{array}{l}\text { Percent Difference } \\
\text { between AASHTO } \\
\text { LRFD DF and FEA DF }\end{array}$ & $\begin{array}{c}\text { AASHTO } \\
\text { Standard DF }\end{array}$ & $\begin{array}{c}\text { Percent Difference } \\
\text { between AASHTO } \\
\text { Standard DF and } \\
\text { FEA DF } \\
\end{array}$ \\
\hline \multirow{18}{*}{ 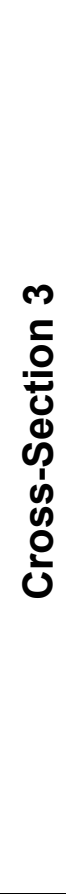 } & 1L1S85F5LD20 & 14.700 & 0.578 & 0.644 & 11 & 0.727 & 26 \\
\hline & 1L1S85F5LD25 & 14.495 & 0.586 & 0.651 & 11 & 0.727 & 24 \\
\hline & 1L1S85F5LD30 & 14.532 & 0.585 & 0.641 & 10 & 0.727 & 24 \\
\hline & 1L1S85F7LD20 & 14.627 & 0.581 & 0.652 & 12 & 0.727 & 25 \\
\hline & 1L1S85F7LD25 & 14.608 & 0.582 & 0.641 & 10 & 0.727 & 25 \\
\hline & 1L1S85F7LD30 & 14.664 & 0.580 & 0.628 & 8 & 0.727 & 25 \\
\hline & 1L2S85F5LD20 & 14.872 & 0.572 & 0.674 & 18 & 0.727 & 27 \\
\hline & 1L2S85F5LD25 & 15.028 & 0.566 & 0.642 & 13 & 0.727 & 28 \\
\hline & 1L2S85F5LD30 & 15.098 & 0.563 & 0.632 & 12 & 0.727 & 29 \\
\hline & 1L2S85F7LD20 & 14.982 & 0.567 & 0.654 & 15 & 0.727 & 28 \\
\hline & 1L2S85F7LD25 & 15.100 & 0.563 & 0.627 & 11 & 0.727 & 29 \\
\hline & 1L2S85F7LD30 & 15.128 & 0.562 & 0.616 & 10 & 0.727 & 29 \\
\hline & 1L3S85F5LD20 & 15.123 & 0.562 & 0.675 & 20 & 0.727 & 29 \\
\hline & 1L3S85F5LD25 & 15.228 & 0.558 & 0.652 & 17 & 0.727 & 30 \\
\hline & 1L3S85F5LD30 & 15.324 & 0.555 & 0.639 & 15 & 0.727 & 31 \\
\hline & 1L3S85F7LD20 & 15.246 & 0.558 & 0.674 & 21 & 0.727 & 30 \\
\hline & 1L3S85F7LD25 & 15.471 & 0.549 & 0.639 & 16 & 0.727 & 32 \\
\hline & 1L3S85F7LD30 & 15.558 & 0.546 & 0.619 & 13 & 0.727 & 33 \\
\hline
\end{tabular}




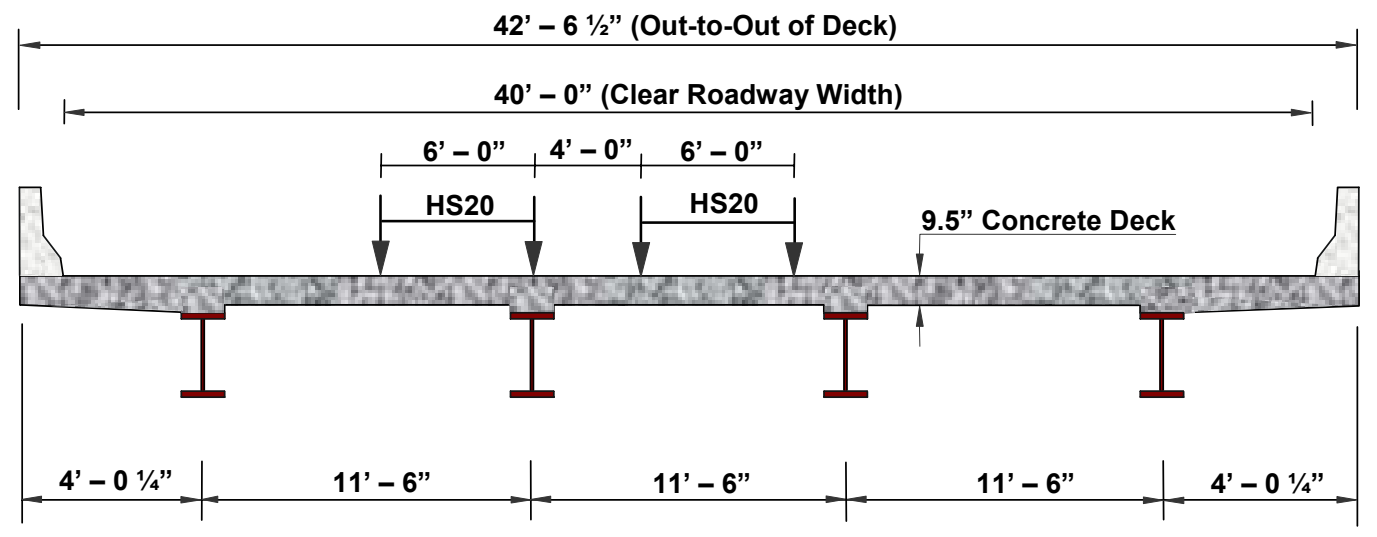

Figure 6.1 Cross-section view and horizontal loading positions for all bridges included in the WVU parametric study for cross-section 1

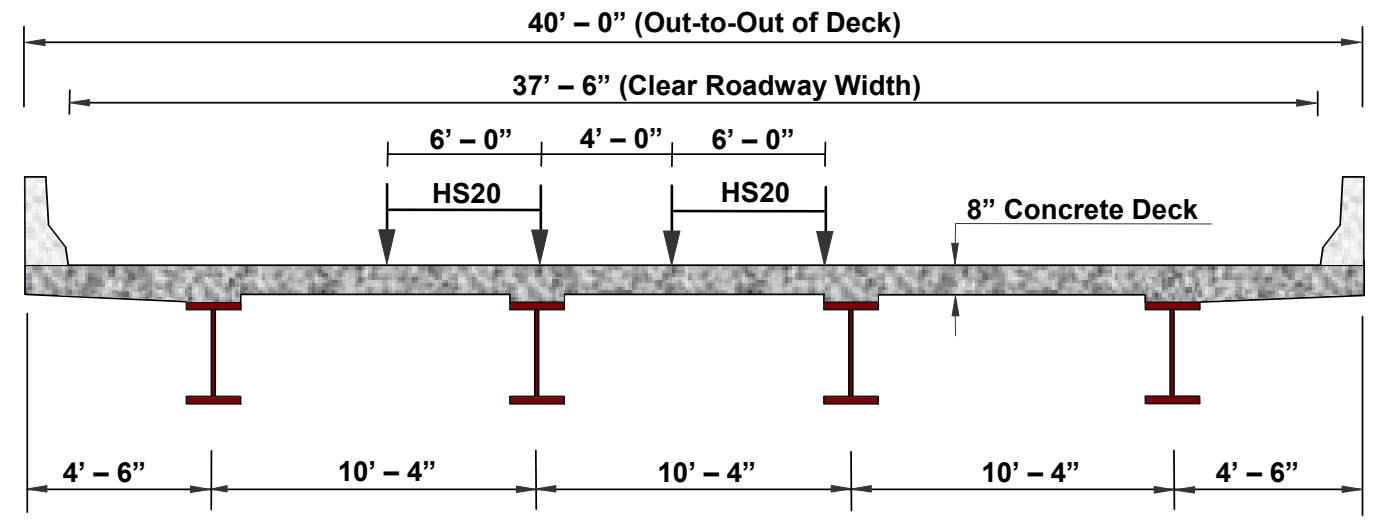

Figure 6.2. Cross-section view and horizontal loading positions for all bridges included in the WVU parametric study for cross-section 2 


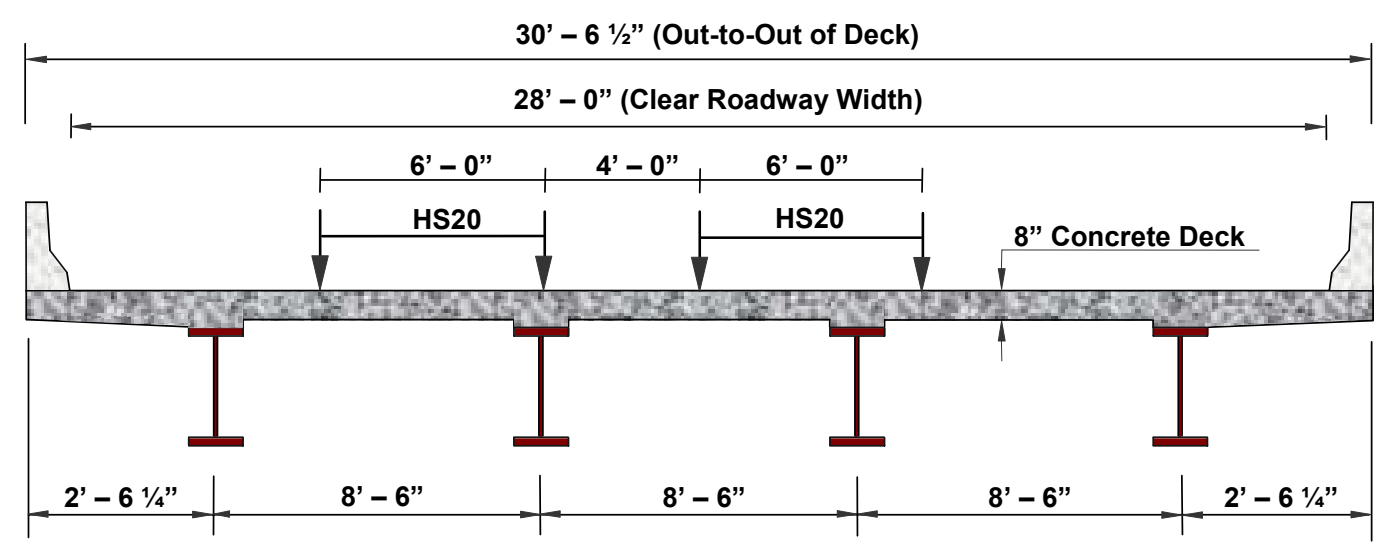

Figure 6.3. Cross-section view and horizontal loading positions for all bridges included in the WVU parametric study for cross-section 3

Span Length, L

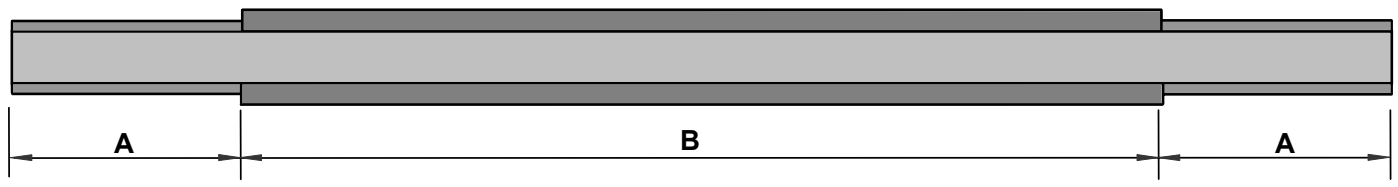

Figure 6.4. Hypothetical girder elevation for girder configurations found in Table 6.1 


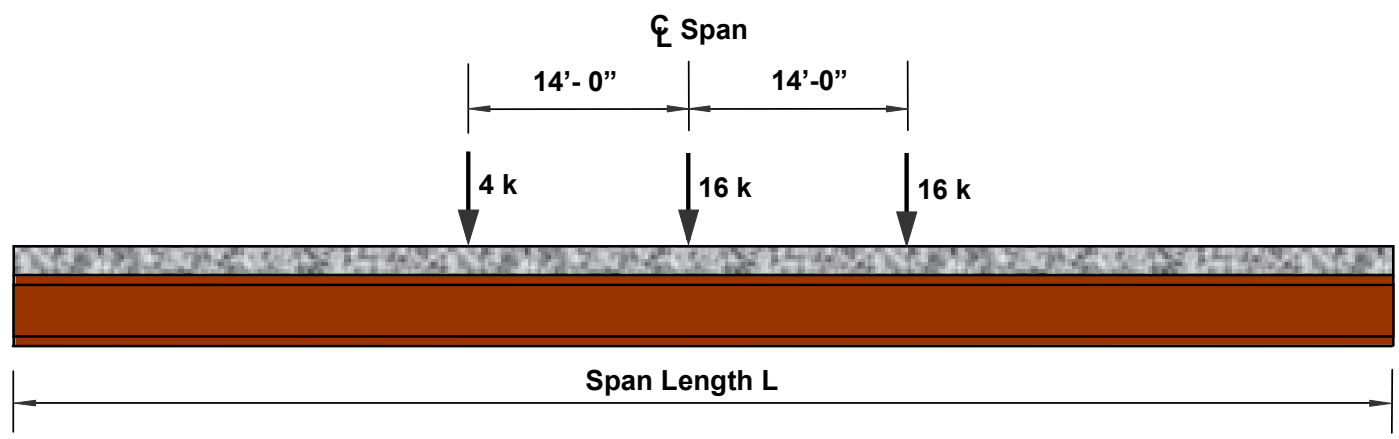

Figure 6.5. Elevation and longitudinal loading positions for girders found in Table 6.1

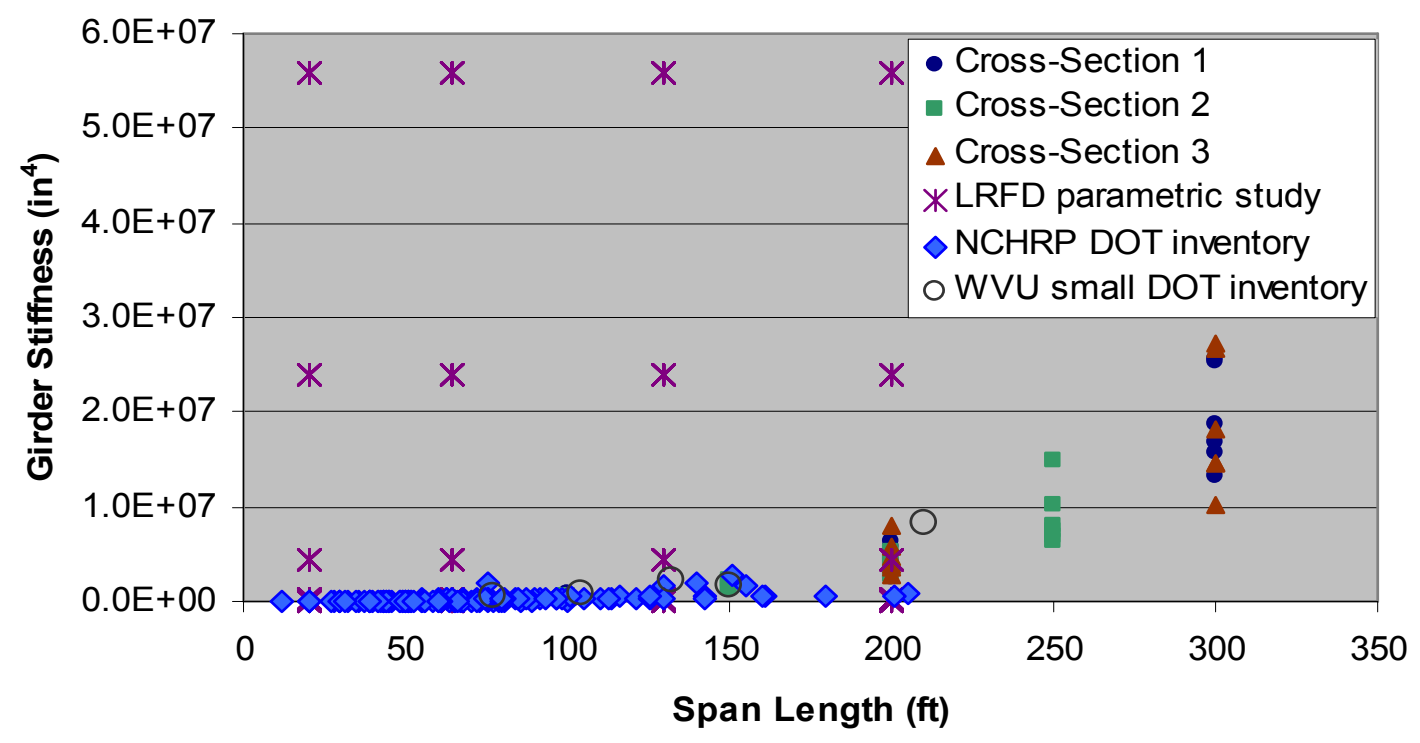

Figure 6.6. Sensitivity study comparing girder stiffness against span length for the WVU parametric study, LRFD parametric study, NCHRP DOT inventory, and WVU small DOT inventory 


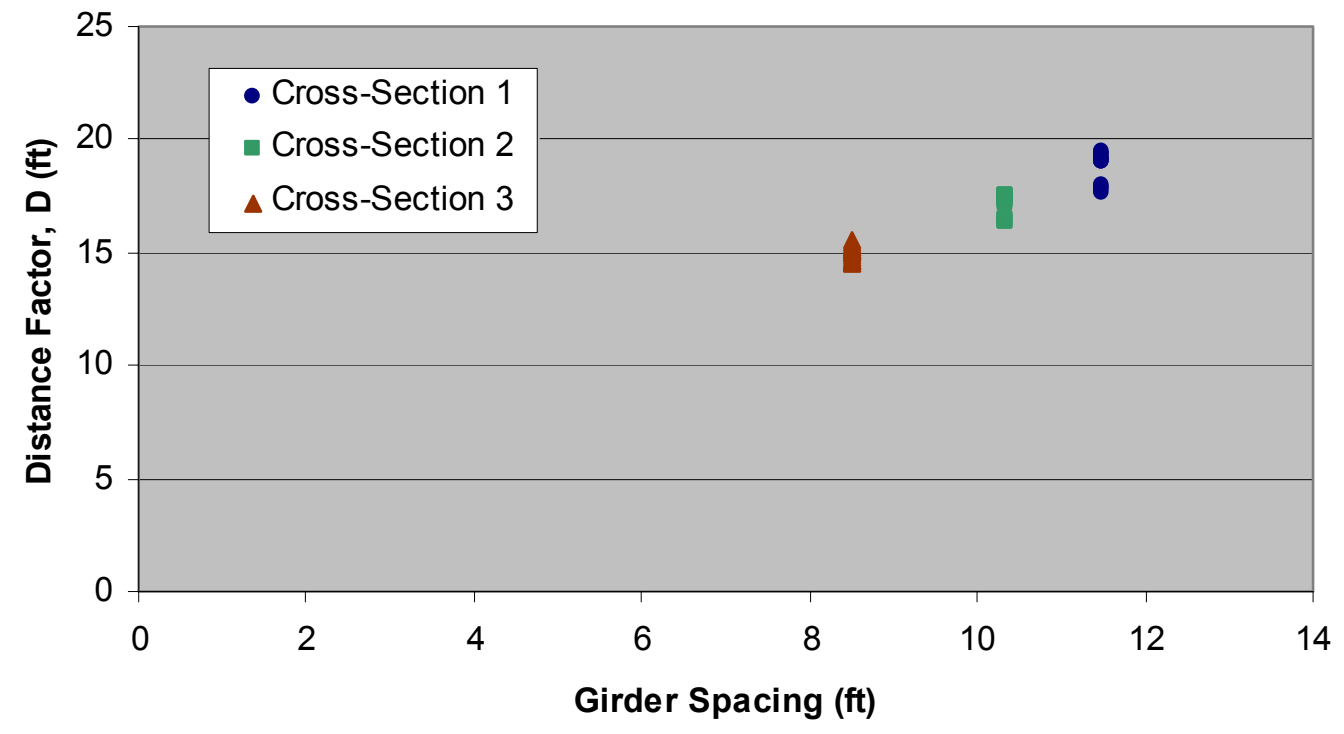

Figure 6.7. Sensitivity study comparing design factor, D, against girder spacing for the WVU parametric study

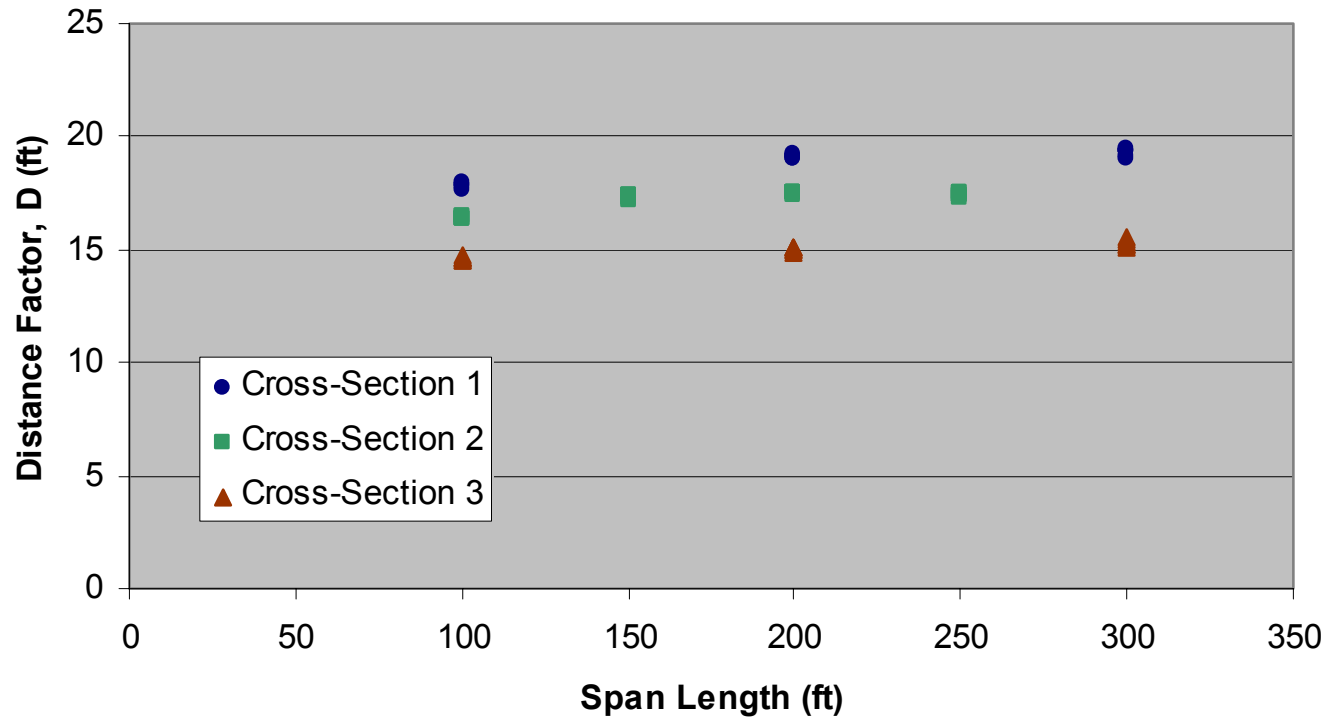

Figure 6.8. Sensitivity study comparing design factor, D, against span length for the WVU parametric study 


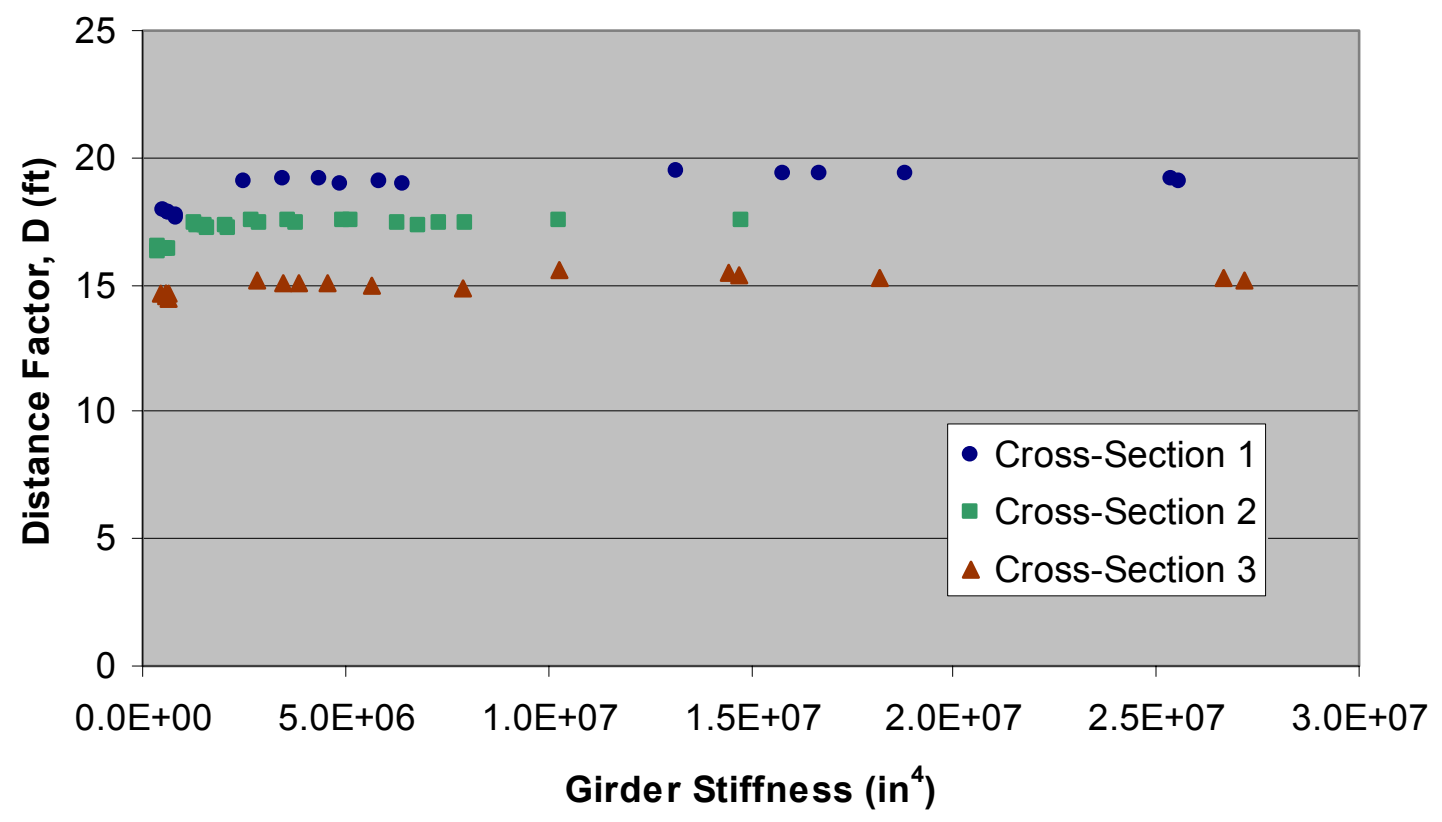

Figure 6.9. Sensitivity study comparing design factor, D, against girder stiffness for the WVU parametric study 


\section{CHAPTER 7}

\section{GENERAL RESULTS AND DEVELOPMENT OF PROPOSED MOMENT DISTRIBUTION FACTORS}

\subsection{Introduction}

The goal of this chapter is to use the analytical results of the parametric studies conducted in Chapter 6 coupled with the associated trends discussed in that chapter to propose a simplified empirical model for the load distribution factor valid for the range of parameters studied in this effort. Sensitivity studies presented in Chapter 6 showed that the two key parameters influencing the design factor, $D_{d f}$, are girder spacing and span length, subsequent sections in this chapter will present a multivariable regression analysis using these parameters to develop an empirical load distribution factor expression. Also, comparisons will be made between the proposed distribution factor equation and current AASHTO Standard and AASHTO LRFD Specifications (AASHTO, 1996; AASHTO, 2002).

\subsection{Development of Proposed Equation}

As stated previously, the OHBDC (1991) uses a load distribution factor expression with a similar format to that incorporated in the AASHTO Standard 
specification. Which has the form

$$
\begin{aligned}
& \text { Distribution Factor }=\frac{S}{D_{d f}} \\
& \text { where } S \quad=\text { girder spacing }(\mathrm{ft}) \\
& D_{d f}=\text { design factor }(\mathrm{ft}) .
\end{aligned}
$$

In the OHBDC, the design factor, $D_{d f}$, is a function of span length, design lane width , and type of superstructure. This parameter was developed by Bakht based on both analytical and parametric studies and was further verified through carefully conducted field tests. This format will be employed in this study with the parameters of girder spacing and span length being used to develop an expression for the design factor, $D_{d f}$, given the analytical results presented in Chapter 6.

The statistical analysis program DataFit 8.0 (2002), created by Oakdale Engineering, was used to aid the process of developing an equation for live load distribution factors. The analysis tool provided accurate results by using multivariable regression to produce an expression for the significant parameters identified in Chapter 6 and determine the accuracy of each expression using a multiple determination value, $\mathrm{R}^{2}$. The expression was set up to use the parameters of girder spacing and span length as independent variables with the design factor set as the dependent variable. The resulting model was found to be

$$
\begin{aligned}
D_{d f}=5.4+1.25 S-\frac{170}{L} & \\
\text { where } D_{d f} & =\text { distance factor }(\mathrm{ft}) \\
S & =\text { girder spacing }(\mathrm{ft}) \\
L & =\text { span length }(\mathrm{ft})
\end{aligned}
$$


which produced an $\mathrm{R}^{2}$ value of 0.983 . Figure 7.1 shows a comparison between the proposed model (Eqn. 7.2) and the results from the FEA modeling.

\subsection{Comparisons of Proposed Equation}

The results from the parametric study presented in Chapter 6 were used to compare the load distribution factors from the analytical studies with these predicted by Eqn. 7.2. Also distribution factors predicted by Eqn. 7.2 are compared against those predicted by both the AASHTO Standard and AASHTO LRFD specifications. Figure 7.2 presents a histogram of the proposed distribution factors compared to actual FEA distribution factors. The figure shows Eqn. 7.2 to provide values that compare well to the FEA values observed in bridges modeled from the parametric study. Figures 7.3 and 7.4 present histograms comparing the distribution factors predicted by Eqn. 7.2 with those predicted by the AASHTO Standard and AASHTO LRFD expressions respectively for the bridges in the parametric study. The figures clearly show that both the AASHTO Standard and AASHTO LRFD expressions are found to produce distribution factors that are conservative when compared against the factors calculated using Eqn. 7.2.

Four DOT bridges modeled from the WVU small inventory falling into the range of parameters presented in Section 6.2 were also analyzed and the resulting distribution factors were compared with those predicted by Eqn. 7.2. Table 7.1 presents the results for distribution factors for the FEA model, proposed equation, AASHTO LRFD, and AASHTO Standard specifications. Similar trends to Figs. 7.1, 7.2, and 7.3 are observed from the values presented in Table 7.1 . 


\subsection{Conclusions}

Comparisons presented in this chapter show the distribution factors predicted by Eqn. 7.2 to correlate well with the analytical results of the bridges in the parametric study as well as those from a select group of actual bridges. Further, these comparisons show both the AASHTO Standard and AASHTO LRFD specifications to produce conservative distribution factors with respect to both the analytical results of the parametric study and the predictions of Eqn. 7.2. It is important to note that Eqn. 7.2 is only applicable to highway bridges that fall into the range of parameters set in Section 6.2. 
Table 7.1. Comparison of distribution factors comparing proposed, AASHTO LRFD, and AASHTO Standard specifications done on four bridges from WVU small bridge inventory, Bakht, and Stallings

\begin{tabular}{|c|c|c|c|c|}
\hline Bridge & FEA DF & Proposed DF & AASHTO LRFD & AASHTO Standard \\
\hline Berks County & 0.562 & 0.597 & 0.795 & 0.985 \\
\hline Cedar Creek & 0.578 & 0.569 & 0.619 & 0.674 \\
\hline Snyder Street & 0.548 & 0.561 & 0.626 & 0.727 \\
\hline Route 20 & 0.557 & 0.594 & 0.701 & 0.864 \\
\hline
\end{tabular}




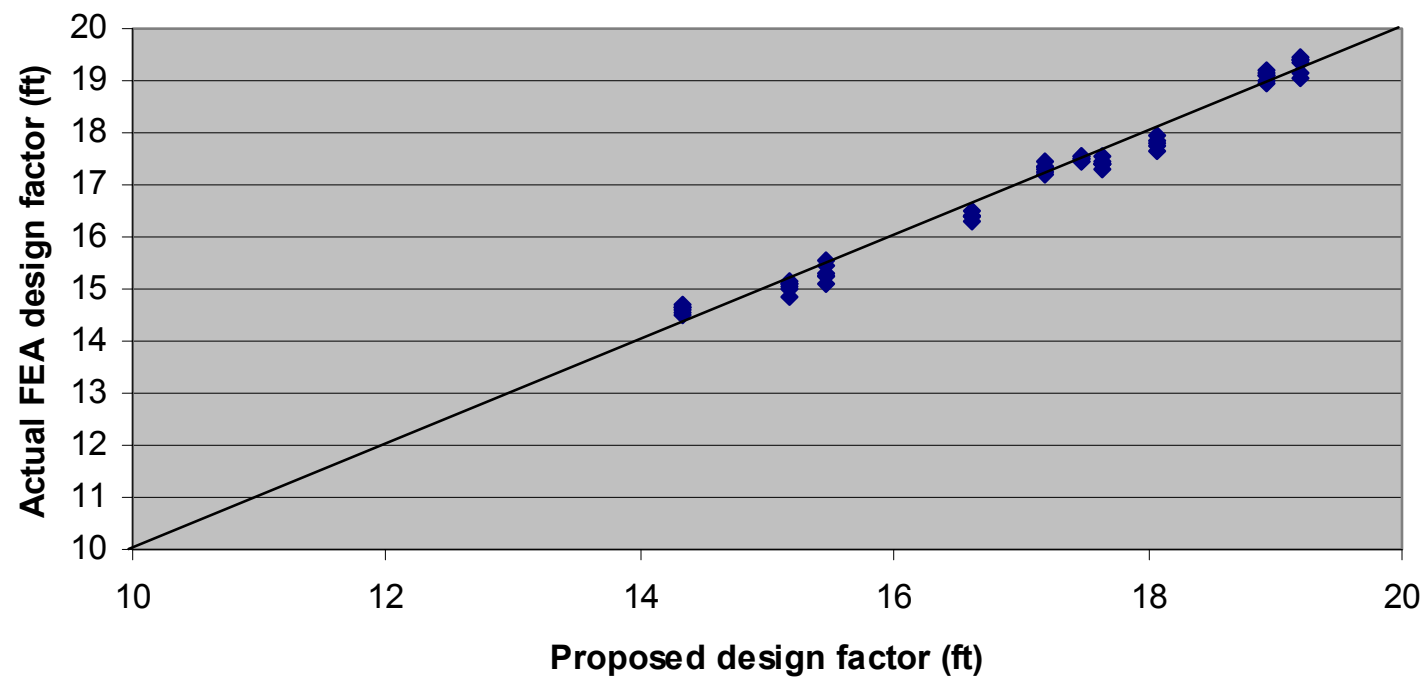

Figure 7.1. Comparison of actual FEA design factor values plotted against proposed design factor values

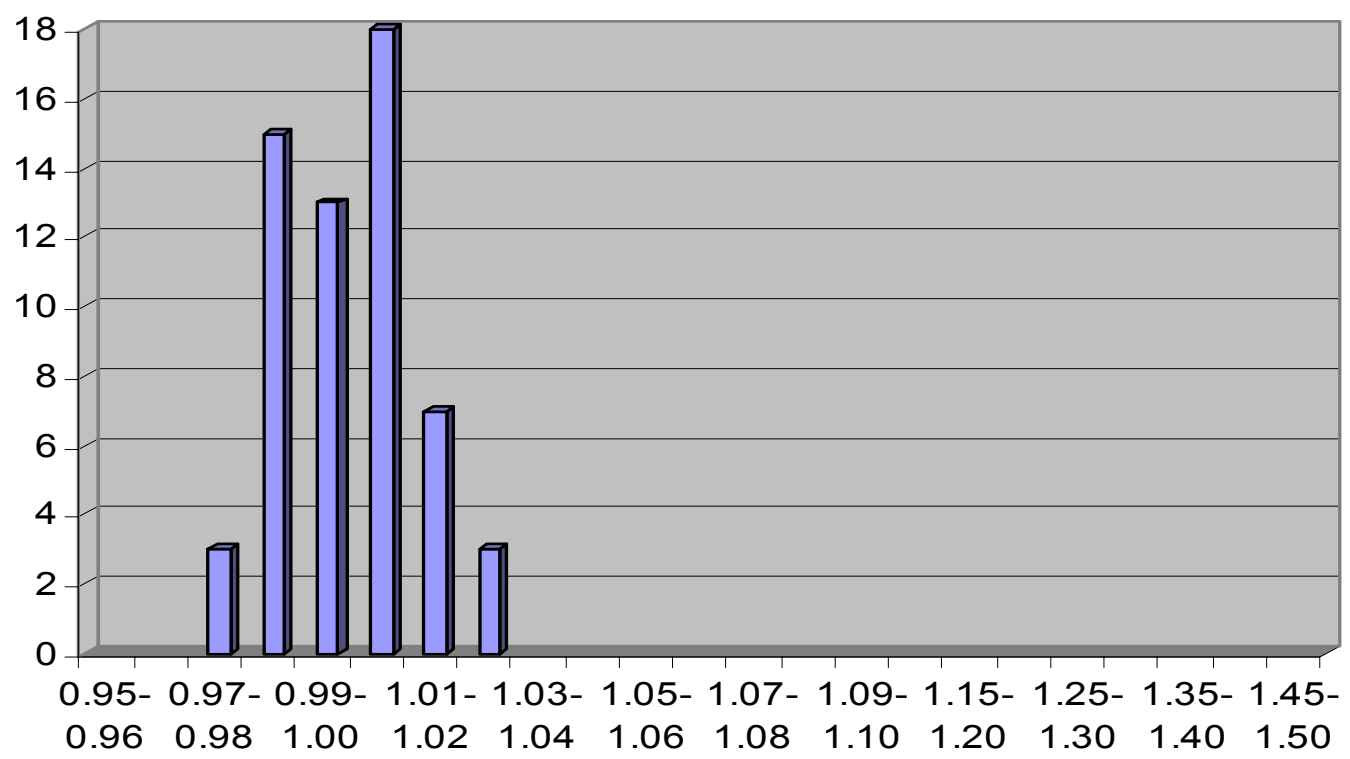

Figure 7.2. Histogram of proposed distribution factors over the actual FEA distribution factors 


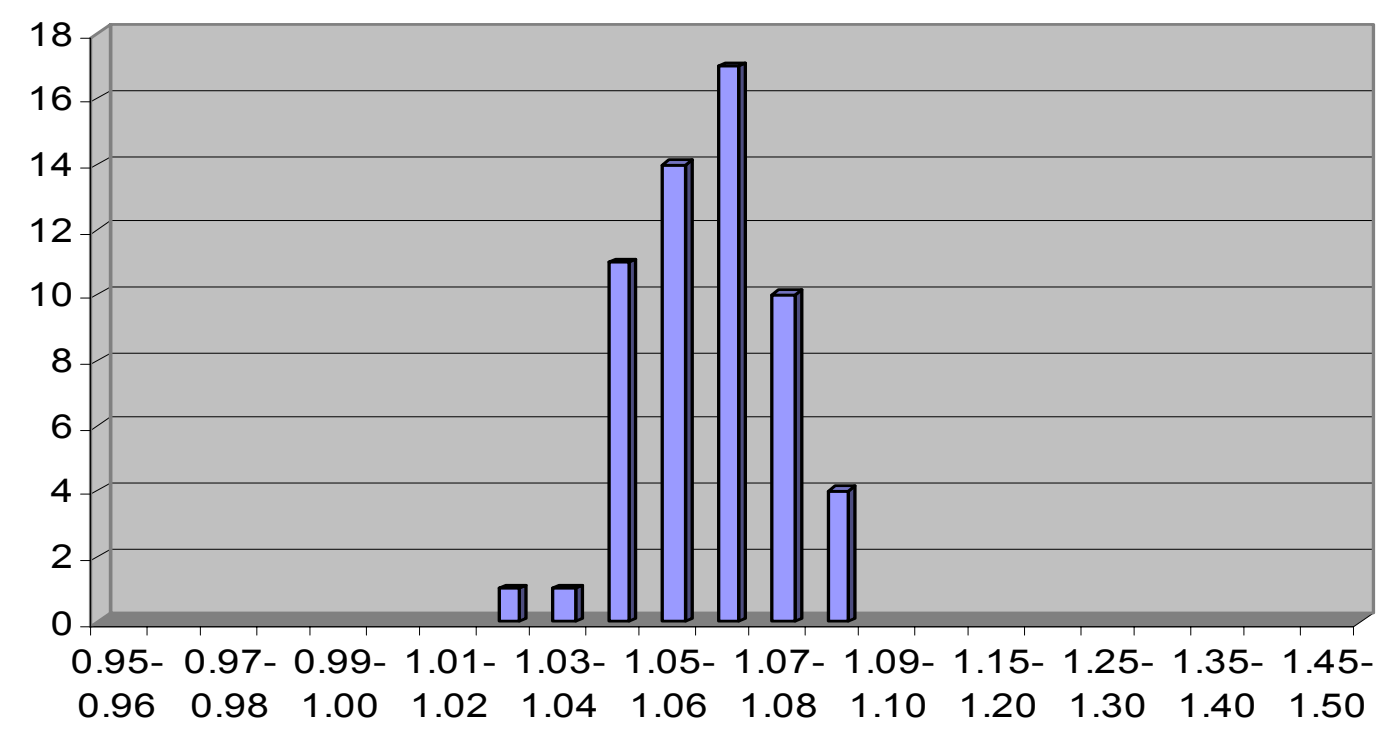

Figure 7.3. Histogram of the AASHTO LRFD distribution factors over the distribution factors calculated from Eqn. 7.2

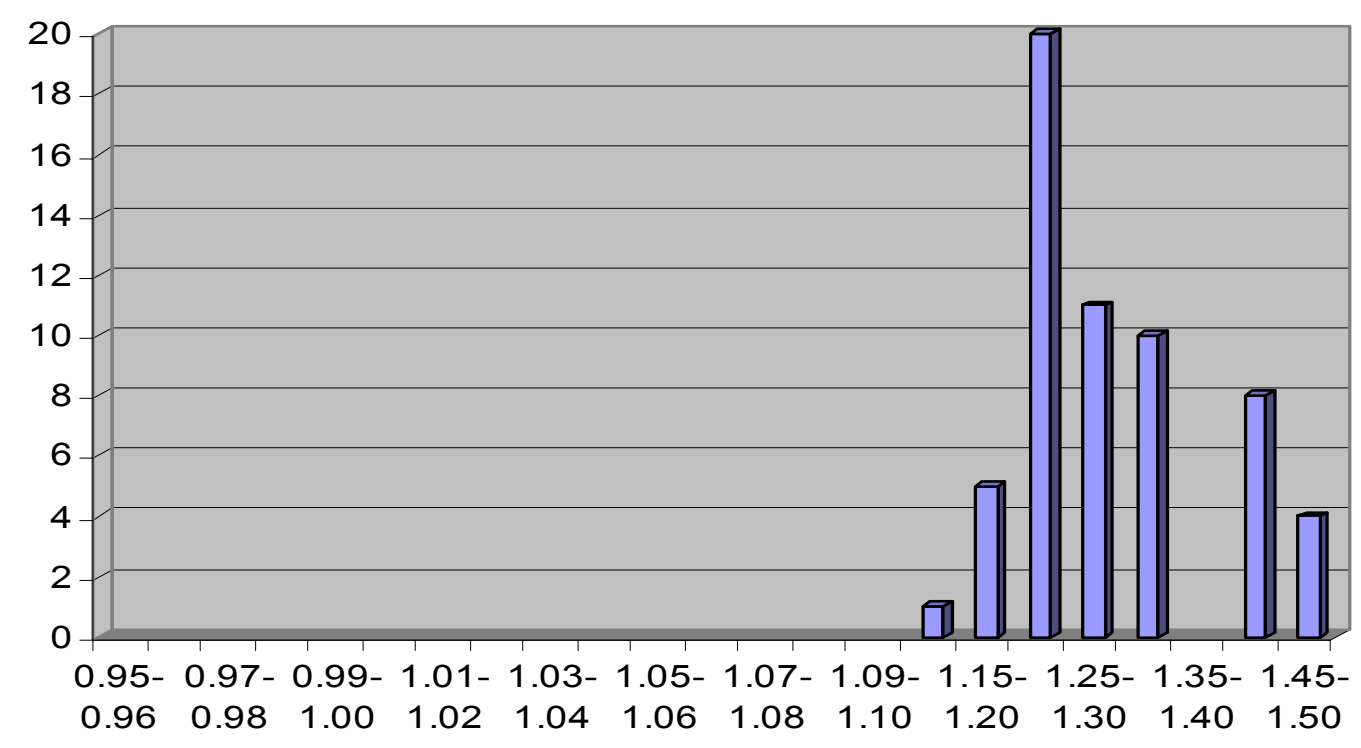

Figure 7.4. Histogram of the AASHTO Standard distribution factors over distribution factors calculated from Eqn. 7.2 


\section{CHAPTER 8}

\section{SUMMARY AND CONCLUDING REMARKS}

\subsection{Scope of Work}

The primary goal of this effort has been to identify and assess various methods of computing live load distribution factors and to use the results of laboratory and field tests to compare these methods. It has further been a goal of this work to use these methods to perform a parametric study over a wide range of typical slab on steel I-girder bridges to assess the accuracy of both the AASHTO Standard and AASHTO LRFD specifications and to propose an empirical model that correlated better with the analytical results within the range of parameters studied.

A comprehensive literature review was conducted to summarize the background, history, and development of the current AASHTO live load distribution factor equations. Literature from previous investigators was reviewed to obtain procedures for calculating load distribution factors from experimental and analytical data. Results from this literature were used to validate analytical modeling employed in this effort and to compare trends observed in the current modeling with these predicted by current specification equations. The FEA modeling tools were then used to perform a discreet parametric study for simply supported slab on I-girder bridges. Results of this parametric study were also compared with current specification equations and were also used to develop a simplified distribution factor equation applicable to the range of parameters investigated. 


\subsection{Summary Results}

Several models for the computation of live load distribution factors were presented with FEA studies performed to assess these models and verify the accuracy of the analytical tools. A refined parametric study was performed using these analytical tools. The results of the parametric study were assessed to identify the most influential variables within the range of study and these were found to be girder spacing and girder span length. Multivariable regression analysis with these parameters was performed to develop a simplified empirical model for the mid-span moment. The model selected was

$$
\begin{aligned}
& \text { Distribution Factor }=\frac{S}{D_{d f}} \\
& \begin{array}{cl}
D_{d f}=5.4+1.25 S-\frac{170}{L} \\
\text { where } \mathrm{S} \quad=\text { girder spacing }(\mathrm{ft}) \\
D_{d f} \quad=\text { design factor }(\mathrm{ft}) .
\end{array}
\end{aligned}
$$

This model had an $\mathrm{R}^{2}$ value of 0.983 .

The results from the analytical models coupled with the results of the simplified prediction model were compared with distribution factors predicted by both the AASHTO Standard and AASHTO LRFD specifications. The comparisons yielded the AASHTO LRFD factors to be $20 \%$ conservative compared with the FEA results, while the AASHTO Standard factors were $29 \%$ conservative. 


\subsection{Future Work}

While the model presented in this work produced robust comparisons with the analytical studies it is important to extend this work over a broader range of parameters to develop generalized load distribution factor models accurate for a wider range of typical U.S. bridges.

This extended study should include a wider range of girder span lengths with a particular point of assessing (1) shorter span length structures and (2) a more comprehensive range of span lengths between $100 \mathrm{ft}$. and $300 \mathrm{ft}$. It should assess a wider range of cross-sections incorporating various girder spacings and numbers of girders in the cross-section. Also it should look at a wider range of loaded lanes.

Additionally it should address such issues as: distribution to exterior girders, specifically looking at edge stiffening effects, girder continuity conditions assessing negative moment distribution, the distribution of shear forces, the influence of skew, and other slab on stringer systems. 


\section{Reference Cited}

AASHTO LFD Standard Specifications, Fourteenth Edition, American Association of State Highway and Transportation Officials, Washington, D.C., 1996

AASHTO LRFD Specifications, Third Edition, American Association of State Highway and Transportation Officials, Washington, D.C., 2002

ABAQUS v.6.3.1 (2002). Users Manuel. Hibbitt, Karlsson, \& Sorensen, Inc., Pawtucket, RI.

AISI Short Span Steel Bridges: Plans and Software. American Iron and Steel Institute. Washington, D.C., 1988

Arockiasamy, M, Amer, A., \& Bell, N. B. (1997, February). Load Distribution on Highway Bridges Based on Field Test Data: Phase II. Draft Final Report.

Australian Bridge Design Code, Standards Association of Australia, Sydney, Australia, 1992.

Bakht, B. \& Jaeger, L.G. (1988). Bearing Restraint in Slab-on-Girder Bridges. Journal of Structural Engineering 114:12, 2724-2740

Bakht, B. (1988, June). Observed Behaviour of a New Medium Span Slab-on-Girder Bridge. Ministry of Transportation, Ontario, Ontario, Canada.

Bakht, B. and Moses, F. (1988, Aug). Lateral Distribution Factors for Highway Bridges. Journal of Structural Engineering, 114:8, 1785-1803. 
Bakht, B. \& Jaeger, L.G. (1990). Bridge Testing - A Surprise Every Time. Journal of Structural Engineering 116:5, 1370-1383.

Barker, M.G., Imhoff, C.M., McDaniel, W. T., \& Frederick, T.L (1999, May). Field Testing and Loading Procedures for Steel Girder Bridges. Report for Missouri Department of Transportation.

Barr, P. J., Eberhard, M. O., \& Stanton, J. F. (2001, Oct./Sept.). Live-Load Distribution Factors in Prestressed Concrete Girder Bridges. Journal of Bridge Engineering 6:5, 298-306.

Barth, K.E., Clingenpeel, B., Christopher, R., Hevener, W., and Wu, H., (2001). Unpublished Design Study, West Virginia University, Morgantown, WV.

Canadian Highway Bridge Design Code, CSA International, Toronto, Ontario, Canada, 2000.

Clingenpeel, B. (2001). The Economical use of High Performance Steel in Slab-on-Steel Stringer Bridge Design. MS Thesis, West Virginia University.

DataFit 8.0 (2002). DataFit v. 8.0®. Oakdale Engineering, Oakdale, PA.

Eom, J. \& Nowak, A. S. (2001, Nov./Dec.). Live Load Distribution for Steel Girder Bridges. Journal of Bridge Engineering, 6:6, 489-497.

Euro Code 2: Steel Bridges, European Committee for Standardization, 2001, Brussels, Belguim.

FEMap v.8.1 (1999). Users Manuel. Enterprise Software Products, Inc., Exton, PA. 
Fu, C. C., Elhelbawey, M., Sahin, M. A., \& Schelling, D. R. (1996, September). Lateral Distribution Factor from Bridge Field Testing. Journal of Structural Engineering, 122:9, 1106-1109.

Hays, C.O., Sessions, L.M., \& Berry, A.J. Further Studies on Lateral Load Distribution Using a Finite Element Method. Transportation Research Record 1072, 6-14.

Kim, S. \& Nowak, A.S. (1997, August). Load Distribution and Impact Factors for IGirder Bridges. Journal of Bridge Engineering, 2:3, 97-104.

Mabsout, M.E., Tarhini, K.M., Frederick, G.R., \& Tayar, C. (1997, August). FiniteElement Analysis of Steel Girder Highway Bridges. Journal of Bridge Engineering, 2:3, 83-87.

Mabsout, M.E., Tarhini, K.M., Frederick, G.R., \& Kobrosly, M. (1997, August). Influence of Sidewalks and Railing on Wheel Load Distribution in Steel Girder Bridges. Journal of Bridge Engineering, 2:3, 88-96.

Mabsout, M.E., Tarhini, K.M., Frederick, G.R., \& Kesserwan, A. (1999, May). Effect of Multilanes on Wheel Load Distribution in Steel Girder Bridges. Journal of Bridge Engineering, 4:2, 99-106.

MDX (September 24, 2001). MDX Curved \& Straight Steel Bridge Design and Rating Software ${ }^{\circledR}$.

Moore, M., Strand, K.A., Grubb, M.A., \& Cayes, L.R. Wheel-Load Distribution Results from AISI-FHWA Model Bridge Study. Transportation Research Record 1275, $34-44$. 
Newmark, N.M. (1938). A Distribution Procedure for the Analysis of Slabs Continuous over Flexible Girders. Eng. Exp. Sta. Bull. 304, 7-118.

Newmark, N.M. (1949). Design of I-Beam Bridges. Transportation ASC, Vol. 114, 9971022.

Newmark, N.M. (1943). Design of Slab and Stringer Highway Bridges. Public Roads, Vol. 23:7, 157-166.

Newmark, N.M. \& Siess, C.P. (1942). Moments in I-beam Bridges. Eng. Exp. Sta. Bull. 336, Vol. XXXIX, No. 44, 1-148.

Newmark, N.M. (1946). Studies of Slab and Beam Highway Bridges, Part I: Tests of Simple Span Right I-beam Bridges. Eng. Exp. Sta. Bull. 363, 1-130.

Newmark, N.M. (1948). Studies of Slab and Beam Highway Bridges, Part II: Tests of Simple Span Skew I-beam Bridges. Eng. Exp. Sta. Bull. 375, 1-61.

Nutt, R.V., Schamber, R.A., \& Zokaie, T. (1988). Distribution of Wheel Loads on Highway Bridges. Final Report for National Cooperative Highway Research Program.

Ontario Highway Bridge Design Code, Third Edition, Ontario Ministry of Transportation and Communications, Downsview, Ontario, Canada, 1991.

Sanders, Jr., W.W. (1984). Distribution of Wheel Loads on Highway Bridges. National Cooperative Highway Research Program Synthesis of Highway Practice 111. 
Shahawy, M. \& Huang, D. (2001, August). Analytical and Field Investigation of Lateral Load Distribution in Concrete Slab-on-Girder Bridges. ASI Structural Journal, 590-599.

Simon v. 8.1 (July 15, 1996). Simon Systems ${ }^{\circledR}$. American Institute of Steel Construction, Chicago, IL.

Stallings, J.M. and Yoo, C.H. (1991, Feb). Bridge Testing. Final Report: Project Number ST 2019-12 for The State of Alabama Highway Department.

Tarhini, K.M. \& Frederick, G.R. (1992). Wheel Load Distribution in I-Girder Highway Bridges. Journal of Structural Engineering, 118:5, 118:5, 1285-1294.

Tiedeman J.L., Albrecht, P., and Cayes, L.R. (1993, April). Behavior of Two-Span Continuous Bridge under Truck Axle Loading. Journal of Structural Engineering, 119:4, 1234-1250.

Walker, W.H. (1987). Lateral Load Distribution Multi-girder Bridges. Engineering Journal, 24:1, 21-28.

Zokaie, T. (2000, May). AASHTO-LRFD Live Load Distribution Specifications. Journal of Bridge Engineering, 5:2, 131-138. 